ФЕДЕРАЛЬНЫЙ ИССЛЕДОВАТЕЛЬСКИЙ ЦЕНТР КОЛЬСКИЙ НАЧЧНЫЙ ЦЕНТР РОССИЙКОЙ АКАДЕМИИ НАУК

$\underset{2020}{1930}$
ИНСТИТУТ ХИМИИ И ТЕХНОЛОГИИ РЕДКИХ ЭЛЕМЕНТОВ И МИНЕРАЛЬНОГО СЫРЬЯ ИМ. И. В. ТАНАНАЕВА ФЕДЕРАЛЬНОГО ИССЛЕДОВАТЕЛЬСКОГО ЦЕНТРА «КОЛЬСКИЙ НАУЧНЫЙ ЦЕНТР РОССИЙСКОЙ АКАДЕМИИ НАУК»

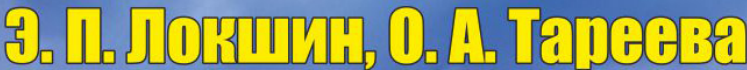

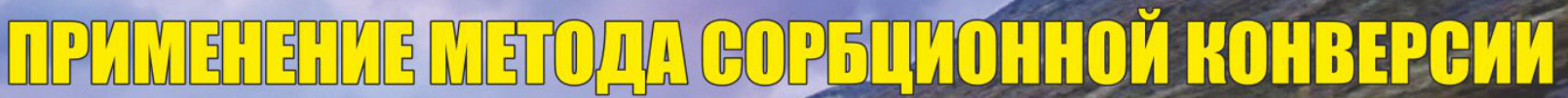

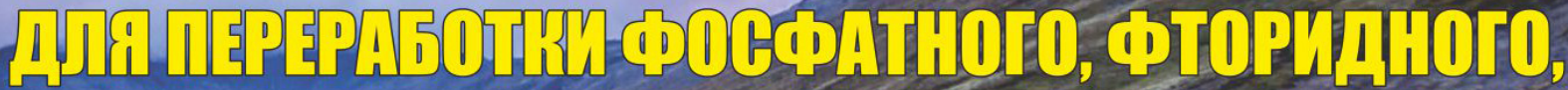

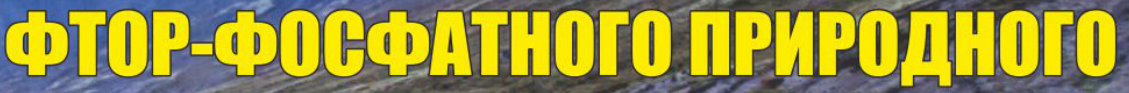

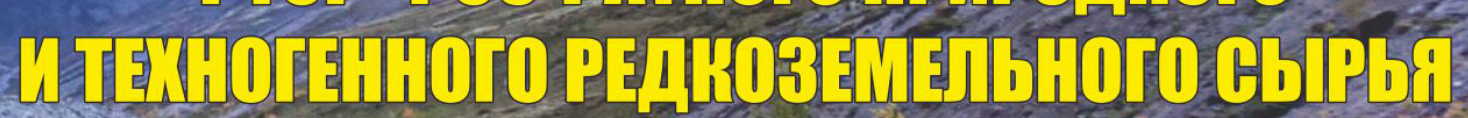

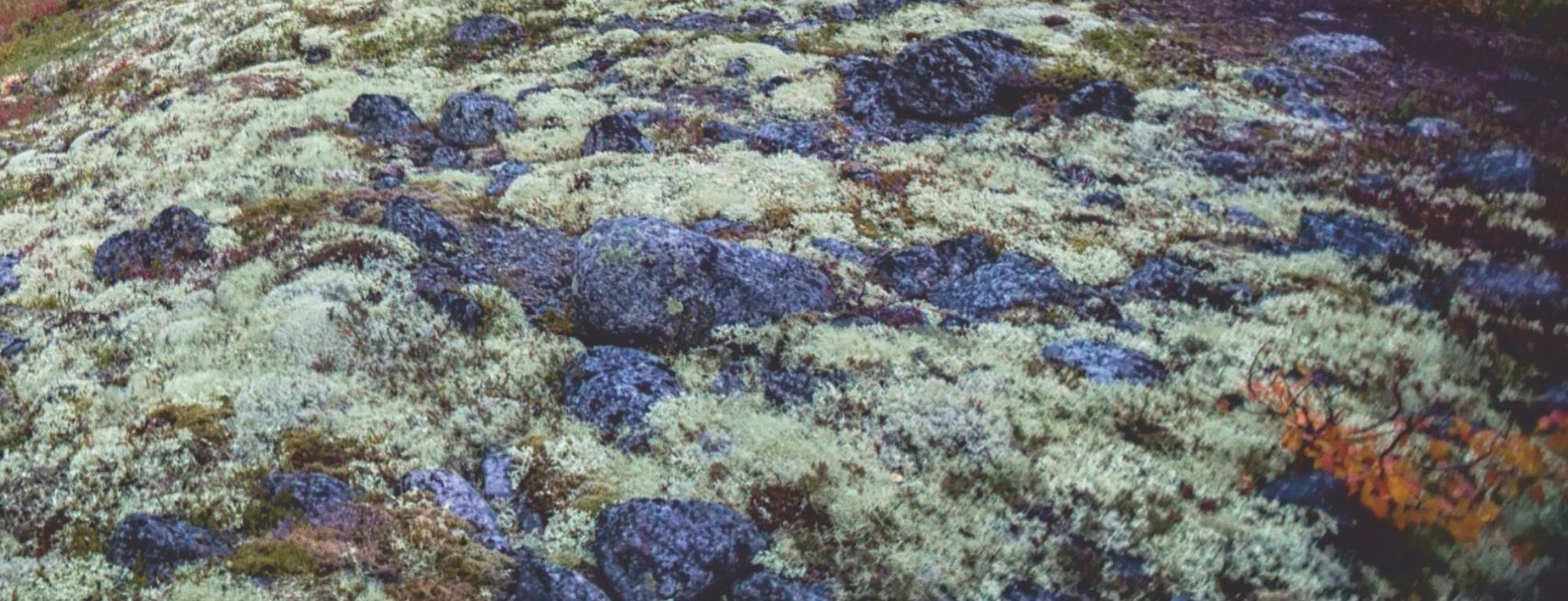


МИНИСТЕРСТВО НАУКИ И ВЫСШЕГО ОБРАЗОВАНИЯ РОССИЙСКОЙ ФЕДЕРАЦИИ

ФЕДЕРАЛЬНЫЙ ИССЛЕДОВАТЕЛЬСКИЙ ЦЕНТР «КОЛЬСКИЙ НАУЧНЫЙ ЦЕНТР РОССИЙСКОЙ АКАДЕМИИ НАУК»

ИНСТИТУТ ХИМИИ И ТЕХНОЛОГИИ РЕДКИХ ЭЛЕМЕНТОВ И МИНЕРАЛЬНОГО СЫРЬЯ им. И. В. ТАНАНАЕВА

Э. П. Локшин, О. А. Тареева

\section{ПРИМЕНЕНИЕ МЕТОДА СОРБЦИОННОЙ КОНВЕРСИИ ДЛЯ ПЕРЕРАБОТКИ ФОСФАТНОГО, ФТОРИДНОГО, ФТОР-ФОСФАТНОГО ПРИРОДНОГО И ТЕХНОГЕННОГО РЕДКОЗЕМЕЛЬНОГО СЫРЬЯ}

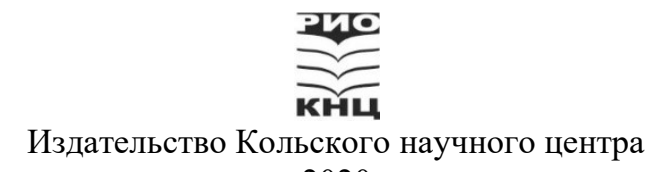


DOI: $10.37614 / 978.5 .91137 .426 .6$

УДК 66.081:553.64:553.49.493

ББК 35

Л73

Печатается по решению редакционно-издательского совета Федерального исследовательского центра «Кольский научный центр Российской академии наук»

\section{Рецензенты:}

доктор технических наук, профессор А. А. Блохин, доктор технических наук, профессор Н. Н. Бушуев, доктор технических наук В. А. Матвеев

Л73 Применение метода сорбционной конверсии для переработки фосфатного, фторидного, фтор-фосфатного природного и техногенного редкоземельного сырья / Э. П. Локшин, О. А. Тареева. — Апатиты: Издательство ФИЦ КНЦ РАН, 2020. - 80 с. : ил.

ISBN 978-5-91137-426-6

Обобщены результаты исследований по разработке технологий переработки фторидного, фосфатного, фтор-фосфатного природного и техногенного редкоземельного сырья. Основное внимание уделено исследованию закономерностей его разложения методом сорбционной конверсии, суть которого состоит во взаимодействии сырья с растворами низкой кислотности в присутствии сильнокислотного катионита - сульфокатионита.

Хотя разложение сырья растворами низкой кислотности должно проходит в малой степени, переходящие в раствор катионы поглощаются сульфокатионитом, что приводит к смещению равновесия. Поскольку из сульфокатионита в кислотный раствор переходят катионы водорода, кислотность раствора практически не снижается, что обеспечивает продолжение разложения сырья. Анионы фтора или/и фосфора накапливаются в растворе. В представленном исследовании показано, как метод сорбционной конверсии можно использовать для разложения различных по природе руд, содержащих редкоземельные элементы.

Книга предназначена для работников химической и металлургической промышленности, научных работников, предпринимателей, интересующихся проблемами получения РЗЭ из минерального сырья. Она может оказаться полезной для обучающихся по соответствующим направлениям студентов высших учебных заведений.

УДК 66.081:553.64:553.49.493

ББК 35

Препринт

Редактор Е. Н. Еремеева

Технический редактор В. Ю. Жиганов

Подписано в печать 11.06.2020. Формат бумаги 60×84 1/16. Усл. печ. л. 4.65. Заказ № 26. Тираж 300 экз.

ISBN 978-5-91137-426-6

(C) Э. П. Локшин, О. А. Тареева, 2020

(c) Институт химии и технологии редких элементов и минерального сырья им. И. В. Тананаева, 2020

(c) ФИЦ «Кольский научный центр

Российской академии наук», 2020 


\section{ОГЛАВЛЕНИЕ}

СПИСОК ПРИНЯТЫХ ОБОЗНАЧЕНИЙ …….................................... 4

ВВЕДЕНИЕ ........................................................................... 5

1. МЕТОДИКА ЭКСПЕРИМЕНТА …………................................... 7

2. ИССЛЕДОВАНИЕ РАЗЛОЖЕНИЯ ФТОРИДНОГО

РЕДКОЗЕМЕЛЬНОГО СЫРЬЯ МЕТОДОМ СОРБЦИОННОЙ

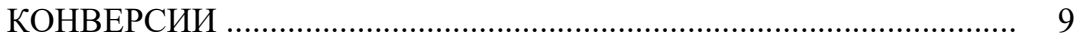

2.1. Разложение бастнезитового концентрата .............................. 9

2.2. Разложение иттрофлюоритового концентрата ...................... 16

3. ИССЛЕДОВАНИЕ РАЗЛОЖЕНИЯ МЕТОДОМ

СОРБЦИОННОЙ КОНВЕРСИИ ФОСФАТНОГО

РЕДКОЗЕМЕЛЬНОГО СЫРЬЯ .................................................... 24

3.1. Разложение монацитового концентрата ................................ 24

3.2. Разложение фосфатного концентрата, осаждаемого из

растворов азотнокислотного разложения апатитового концентрата ............................................................... 34

3.2.1. Разложение с использованием азотнокислых растворов ............................................................. 34

3.2.2. Разложение с использованием фторсодержащих азотнокислых растворов .......................................... 39

3.2.3. Разложение с использованием фосфорнокислых растворов …….................................................... 46

4. СЕРНОКИСЛОТНОЕ РАЗЛОЖЕНИЕ ФТОР-ФОСФАТНОГО КОНЦЕНТРАТА, ОСАЖДЁННОГО ИЗ ЭКСТРАКЦИОННОЙ ФОСФОРНОЙ КИСЛОТЫ ДИГИДРАТНОГО ПРОЦЕССА ............. 54

5. ПЕРЕРАБОТКА СОДЕРЖАЩИХ РЕДКОЗЕМЕЛЬНЫЕ

ЭЛЕМЕНТЫ СОРБЕНТОВ

6. ПУТИ ПРАКТИЧЕСКОЙ РЕАЛИЗАЦИИ МЕТОДА

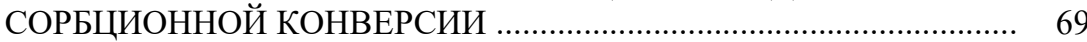

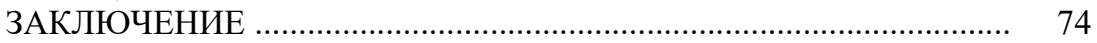

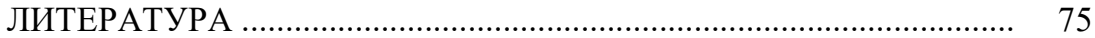




\section{СПИСОК ПРИНЯТЫХ ОБОЗНАЧЕНИЙ}

РЗЭ - редкоземельные элементы (здесь иттрий и лантаноиды)

$\sum \mathrm{Tr}_{2} \mathrm{O}_{3}$ - сумма оксидов (III) редкоземельных элементов

$ß-$ расход сорбента в \% от стехиометрически необходимого

$\varepsilon_{A}$ - извлечение вещества $A$, отн. \%

$C_{A}$ - концентрация вещества $A$

$t$ - температура, ${ }^{\circ} \mathrm{C}$

$V_{\mathrm{p}}$ - объём раствора

$V_{\text {c }}$ - объём сорбента

Ж : Т — отношение объёма жидкой фазы $\left(\right.$ дм$\left.^{3}\right)$ к массе твёрдого (кг)

$A_{\text {эфф. }}$ - удельная эффективная радиоактивность, КБк ${ }^{-1} \Gamma^{-1}$

Н. а. - не анализировали 


\section{ВВЕДЕНИЕ}

Среди имеющих промышленное значение источников сырья редкоземельных металлов широко представлены фторидные (бастнезит, иттрофлюорит, иттросинхизит, паризит и др.) и фосфатные (монацит, ксенотим, апатит и др.) минералы. Фосфатные концентраты Р3Э получают при азотнокислотной переработке апатитового концентрата [1], фтор-фосфатные могут быть получены при его сернокислотной переработке [2].

В промышленности для получения редкоземельной продукции из фторидного и фосфатного сырья используются различные методы $[3,4]$. Анализ показывает, что известные технологии разложения сырья основаны на применении высокотемпературных процессов с высоким расходом реагентов. Это определяет увеличение количества образующихся отходов и расхода энергоресурсов, усиление коррозионного разрушения аппаратуры. При переработке фторидного сырья в ряде случаев соединения фтора переходят в газовую фазу, и для их улавливания требуются значительные усилия. Поэтому разработка более эффективных технических решений для переработки фосфатного и фторидного редкоземельного сырья является актуальной задачей.

В настоящей работе обобщены результаты выполненных авторами исследований по разработке технологий переработки фторидного, фосфатного, фтор-фосфатного природного и техногенного редкоземельного сырья. Основное внимание уделено исследованию закономерностей его разложения методом сорбционной конверсии.

Суть метода сорбционной конверсии состоит во взаимодействии сырья с растворами низкой кислотности в присутствии сильнокислотного катионита - сульфокатионита. Хотя разложение сырья растворами низкой кислотности проходит в малой степени, переходящие в раствор катионы поглощаются сульфокатионитом, что приводит к смещению равновесия. Из сульфокатионита в кислотный раствор переходят катионы водорода, поэтому кислотность раствора практически не снижается, что обеспечивает продолжение разложения сырья. Анионы фтора или/и фосфора накапливаются в растворе.

В качестве кислотных сред для проведения процессов применялись либо низкоконцентрированные растворы сильных кислот (хлористоводородной, азотной, серной), либо концентрированные растворы ортофосфорной кислоты. Найдено, что при переработке фторидного сырья возможно применение растворов фтористоводородной кислоты. Физикохимические основы разложения сырья методом сорбционной конверсии описаны раннее в работе [5].

Результаты получены в Институте химии и технологии редких элементов и минерального сырья им. И. В. Тананаева ФИЦ (ИХТРЭМС) 
КНЦ РАН при выполнении государственного задания «Разработка эффективных методов получения функциональных материалов на основе соединений редких металлов».

Авторы признательны за выполнение химико-аналитических исследований сотрудникам лаборатории химических и оптических методов анализа, особенно кандидату технических наук И. Р. Елизаровой, Н. В. Серба, О. В. Рыбалкиной.

Авторы выражают благодарность рецензентам: заведующему кафедрой технологии редких элементов и наноматериалов Санкт-Петербургского государственного технологического института (Технического университета) доктору технических наук, профессору А. А. Блохину, доктору технических наук, профессору кафедры общей и неорганической химии Российского химико-технологического университета им. Д. И. Менделеева Н. Н. Бушуеву, заведующему лабораторией химии и технологии щелочного алюмосиликатного сырья ИХРЭМС КНЦ РАН доктору технических наук В. А. Матвееву за замечания, способствовавшие улучшению работы. 


\section{1. МЕТОДИКА ЭКСПЕРИМЕНТА}

Для лабораторных экспериментов по разложению концентратов использовали реактор с крышкой, через центральное отверстие которой проходил вал мешалки. Лопасти мешалки плотно примыкали к дну реактора, что исключало возможность попадания разлагаемого минерала в «мёртвую» зону. Детали реактора были изготовлены из фторопласта-4 (ГОСТ 10007-80).

Опыты проводили следующим образом. Навеску исследуемого концентрата, заданное количество гелевого сульфокатионита КУ-2-8чС (ГОСТ 20298-74) и кислотный раствор помещали в реактор. В качестве растворов использовали кислоты низких концентраций квалификации «х. ч.»: $\mathrm{H}_{2} \mathrm{SO}_{4}$ (ГОСТ 4204-77), $\mathrm{HNO}_{3}$ (ГОСТ 4461-77), HCl (ГОСТ 3118-77), НF (ГОСТ 10484-78), а также $\mathrm{H}_{3} \mathrm{PO}_{4}$ (ГОСТ 6552-80) средней и низкой концентраций.

Как правило, сорбент использовали в $\mathrm{H}^{+}$-форме. Его расход оценивали в процентах к стехиометрически необходимому. Под стехиометрически необходимым понимали расход, при котором эквивалентное количество содержащихся в сорбенте функциональных групп равнялось суммарному эквивалентному количеству содержащихся в навеске концентрата катионов металлов. В течение определённого времени загруженные реагенты перемешивали при заданной температуре. Термическая и химическая устойчивость сульфокатионита определяет верхний предел используемого температурного интервала, который в наших работах не превышал $80{ }^{\circ} \mathrm{C}$. Обычно после завершения взаимодействия пульпу отделяли от сорбента на сетчатом фильтре, из пульпы отфильтровывали твёрдый остаток, если он оставался. В ранних опытах при исследовании сернокислотного разложения фтор-фосфатного концентрата, осаждённого из экстракционной фосфорной кислоты дигидратного процесса, твёрдую взвесь и маточный раствор анализировали совместно, предварительно растворив твёрдую взвесь соляной кислотой.

Десорбцию исследовали в статических условиях при заданном

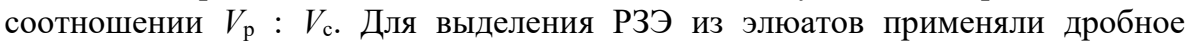
гидролитическое осаждение. Элюаты ступенчато нейтрализовали до заданных величин $\mathrm{pH}$, выпадавшие остатки отделяли фильтрованием.

Получавшиеся растворы и твёрдые продукты анализировали на содержание катионов аттестованным масс-спектрометрическим методом с индуктивно-связанной плазмой (масс-спектрометр ELAN 9000 DRC-e (Perkin Elmer, США)). Твёрдые продукты предварительно растворяли в соляной кислоте. В отдельных опытах для определения концентрации некоторых металлов использовали методы фотометрии пламени или атомной адсорбции. 
Концентрацию фтора определяли потенциометрическим методом, фосфора фотоколориметрическим методом по окраске фосфорномолибденовой сини.

Массы перешедших в продукты компонентов рассчитывали по количеству продуктов и концентрации компонентов в них. Количество поглощённых сорбентом компонентов определяли как разницу между количеством в исходной загрузке и их суммарным количеством в маточном растворе и неразложившемся остатке.

Характеристики использовавшегося сырья и материалов приводятся в соответствующих разделах работы. 


\section{2. ИССЛЕДОВАНИЕ РАЗЛОЖЕНИЯ ФТОРИДНОГО РЕДКОЗЕМЕЛЬНОГО СЫРЬЯ МЕТОДОМ СОРБЦИОННОЙ КОНВЕРСИИ}

\section{1. Разложение бастнезитового концентрата}

Бастнезитовые концентраты являются одним из основных используемых в мировой промышленной практике источников получения РЗЭ. Они характеризуются высоким содержанием РЗЭ преимущественно цериевой группы. Бастнезит представляет собой фторкарбонат (Ce, La, Y) $\mathrm{CO}_{3} \mathrm{~F}$. Его переработка прежде всего требует обесфторивания, чтобы исключить в процессе последующего кислотного растворения образование малорастворимых фторидов РЗЭ.

Информация о методах переработки бастнезитовых концентратов обобщена в работе [3]. Для их разложения предложены, а в ряде случаев промышленно используются: спекание с концентрированной $\mathrm{H}_{2} \mathrm{SO}_{4}$ при $480{ }^{\circ} \mathrm{C}$, хлорирование при температуре $1000-1200{ }^{\circ} \mathrm{C}$, прокалка для удаления $\mathrm{CO}_{2}$ и окисления $\mathrm{Ce}^{3+}$ в $\mathrm{Ce}^{4+}$ при температуре 620 или $800-900{ }^{\circ} \mathrm{C}$ с последующим выщелачиванием соответственно соляной или азотной кислотой.

Предложено [6] смешивать бастнезитовый концентрат с концентрированной серной кислотой, взятой в количестве $100-150 \%$ от стехиометрически необходимого для образования сульфатов $(0,6-0,66$ т 96 мас. $\% \mathrm{H}_{2} \mathrm{SO}_{4}$ на 1 т концентрата), формировать гранулы, прогревать их в течение 0,5-3 ч при температуре $200-300{ }^{\circ} \mathrm{C}$ с удалением в газовую фазу углекислого газа и соединений фтора $\left(\mathrm{SiF}_{4}, \mathrm{HF}\right)$, выщелачивать водой образовавшиеся сульфаты редкоземельных элементов, осаждать РЗЭ из растворов в виде двойных сульфатов с натрием. Двойные сульфаты РЗЭ конвертировались в гидроксиды обработкой растворами гидроксида или карбоната натрия. Из охлаждённых маточных растворов осаждали поливалентные катионы железа и марганца с получением раствора сульфата натрия, часть которого используется в обороте для осаждения двойных сульфатов РЗЭ и натрия. По этой технологии извлечение РЗЭ в гидроксидный продукт составляло 88,8-93,9\%.

Сернокислотная технология разложения бастнезитового концентрата применяется в КНР. Недостатками её являются: повышенный расход реагентов (серной кислоты, гидроксида или карбоната натрия); образование большого количества требующего утилизации раствора, содержащего сульфаты примесных элементов и часть тория; повышенный расход энергии из-за высокой температуры ведения процесса сернокислотной обработки; необходимость организации улавливания из газовой фазы соединений фтора. 
Переход фтора в газовую фазу может быть исключён при использовании гидрометаллургических методов разложения. В реализованной фирмой Molykorp (США) технологии предварительно прокалённый при температуре $620^{\circ} \mathrm{C}$ концентрат выщелачивался 20 мас. \% $\mathrm{HCl}$ в течение 4 ч при $95{ }^{\circ} \mathrm{C}$. Расход $100 \% \mathrm{HCl}$ составлял 0,5 кг на 1 кг $\sum \mathrm{Tr}_{2} \mathrm{O}_{3}$, при этом часть РЗЭ переходила в раствор, а часть в виде фторидов оставалась в остатке. Фториды РЗЭ переводились в гидроксиды обработкой раствором $\mathrm{NaOH}$ с расходом 0,73 кг $\mathrm{NaOH}$ на 1 кг $\sum \mathrm{Tr}_{2} \mathrm{O}_{3}$. Уравнения реакций приведены ниже [7]:

$$
\begin{aligned}
& \operatorname{TrCO}_{3} \mathrm{~F}+9 \mathrm{HCl} \rightarrow \downarrow \operatorname{TrF}_{3}+2 \mathrm{TrCl}_{3}+3 \mathrm{HCl}+3 \mathrm{H}_{2} \mathrm{O}+3 \mathrm{CO}_{2} ; \\
& \operatorname{TrF}_{3}+3 \mathrm{NaOH} \rightarrow \downarrow \operatorname{Tr}(\mathrm{OH})_{3}+3 \mathrm{NaF} ; \\
& \operatorname{Tr}(\mathrm{OH})_{3}+3 \mathrm{HCl} \rightarrow \operatorname{TrCl}_{3}+3 \mathrm{H}_{2} \mathrm{O} .
\end{aligned}
$$

Извлечение РЗЭ составляло около 94 \%. К недостаткам технологии следует отнести значительный расход соляной кислоты и гидроксида натрия и, как следствие, образование большого количества требующих утилизации солянокислых и щелочных фторсодержащих растворов.

В наших исследованиях по сорбционной конверсии использовали бастнезитовый концентрат фирмы Mountain Pass (США), химический состав которого приведён в табл. 1 , сульфокатионит КУ-2-8чС, кислоты $\mathrm{H}_{2} \mathrm{SO}_{4}, \mathrm{HNO}_{3}, \mathrm{HCl}$.

\begin{tabular}{|c|c|c|c|c|c|c|c|c|c|c|c|}
\hline \multicolumn{12}{|c|}{ Содержание, мас. \% } \\
\hline $\mathrm{Y}_{2} \mathrm{O}_{3}$ & \multicolumn{2}{|c|}{$\mathrm{La}_{2} \mathrm{O}_{3}$} & \multicolumn{2}{|c|}{$\mathrm{Ce}_{2} \mathrm{O}_{3}$} & $\mathrm{Pr}_{2} \mathrm{O}_{3}$ & $\mathrm{Nd}_{2} \mathrm{O}_{3}$ & \multicolumn{2}{|c|}{$\mathrm{Sm}_{2} \mathrm{O}_{3}$} & \multicolumn{2}{|c|}{$\mathrm{Eu}_{2} \mathrm{O}_{3}$} & $\mathrm{Gd}_{2} \mathrm{O}_{3}$ \\
\hline 0,0563 & \multicolumn{2}{|c|}{24,02} & \multicolumn{2}{|c|}{33,16} & 2,619 & 7,797 & \multicolumn{2}{|c|}{0,475} & \multicolumn{2}{|c|}{0,0701} & 0,778 \\
\hline $\mathrm{Tb}_{2} \mathrm{O}_{3}$ & \multicolumn{2}{|c|}{$\mathrm{Dy}_{2} \mathrm{O}_{3}$} & \multicolumn{2}{|c|}{$\mathrm{Ho}_{2} \mathrm{O}_{3}$} & $\mathrm{Er}_{2} \mathrm{O}_{3}$ & $\mathrm{Tm}_{2} \mathrm{O}_{3}$ & \multicolumn{2}{|c|}{$\mathrm{Yb}_{2} \mathrm{O}_{3}$} & \multicolumn{2}{|c|}{$\mathrm{Lu}_{2} \mathrm{O}_{3}$} & $\sum \mathrm{Tr}_{2} \mathrm{O}_{3}$ \\
\hline 0,0398 & \multicolumn{2}{|c|}{0,0233} & \multicolumn{2}{|c|}{0,00299} & 0,00577 & 0,00024 & \multicolumn{2}{|c|}{0,00338} & \multicolumn{2}{|c|}{0,00024} & 69,05 \\
\hline $\mathrm{Li}_{2} \mathrm{O}$ & \multicolumn{2}{|c|}{$\mathrm{Na}_{2} \mathrm{O}$} & \multicolumn{2}{|c|}{$\mathrm{K}_{2} \mathrm{O}$} & $\mathrm{MgO}$ & $\mathrm{CaO}$ & \multicolumn{2}{|c|}{$\mathrm{SrO}$} & \multicolumn{2}{|c|}{$\mathrm{BaO}$} & $\mathrm{ZnO}$ \\
\hline 0,0073 & \multicolumn{2}{|c|}{1,01} & \multicolumn{2}{|c|}{0,89} & 0,30 & 3,76 & \multicolumn{2}{|c|}{4,33} & \multicolumn{2}{|c|}{2,51} & 0,0045 \\
\hline $\mathrm{Al}_{2} \mathrm{O}_{3}$ & \multicolumn{2}{|c|}{$\mathrm{TiO}_{2}$} & \multicolumn{2}{|c|}{$\mathrm{ZrO}_{2}$} & $\mathrm{PbO}$ & $\mathrm{Nb}_{2} \mathrm{O}_{5}$ & \multicolumn{2}{|c|}{$\mathrm{Sb}_{2} \mathrm{O}_{5}$} & \multicolumn{2}{|c|}{$\mathrm{WO}_{3}$} & $\mathrm{MnO}$ \\
\hline 0,074 & \multicolumn{2}{|c|}{0,0018} & \multicolumn{2}{|c|}{0,00087} & 0,11 & 0,0033 & \multicolumn{2}{|c|}{0,0036} & \multicolumn{2}{|c|}{0,0018} & 0,043 \\
\hline $\mathrm{Fe}_{2} \mathrm{O}_{3}$ & \multicolumn{2}{|c|}{$\mathrm{NiO}$} & \multicolumn{2}{|c|}{$\mathrm{ThO}_{2}$} & $\mathrm{UO}_{2}$ & $\mathrm{CO}_{3}{ }^{2-}$ & \multicolumn{2}{|c|}{$\mathrm{P}_{2} \mathrm{O}_{5}$} & & $\mathrm{~F}$ & $\mathrm{SO}_{4}{ }^{2-}$ \\
\hline 0,47 & 0,00 & & & 116 & 0,0134 & 26,5 & 1 , & 02 & & 05 & 1,47 \\
\hline & & & & КВ. К & НОВ В & 000 г ко1 & центр & ата & & & \\
\hline $\mathrm{Na}^{+}$ & $\mathrm{K}^{+}$ & $\mathrm{Mg}$ & & $\mathrm{Ca}^{2}$ & $\mathrm{Sr}^{2+}$ & $\mathrm{Ba}^{2+}$ & $\mathrm{Fe}^{3+}$ & $\sum$ & $\Gamma r^{3+}$ & $\mathrm{Th}^{4+}$ & $\sum$ \\
\hline 0,33 & 0,19 & 0 , & & 1,34 & 0,83 & 0,33 & 0,18 & &, 55 & 0,02 & 15,92 \\
\hline
\end{tabular}

Таблий 1

Химический состав бастнезитового концентрата 
У бастнезитового концентрата $A_{\text {эфф. }} \approx 5000$ Бк`к ${ }^{-1}$. Данный концентрат относится к IV классу материалов с повышенным содержанием природных радионуклидов [8].

Основные рудные минералы месторождения Mountain Pass: кальцит (40\%), барит-целестин (25\%), стронцианит (10\%), бастнезит (12\%), кварц (5 \%) [9]. В бастнезитовом концентрате по данным рентгенофазового и кристаллооптического анализов найдены бастнезит $(\mathrm{Ce}, \mathrm{La})\left(\mathrm{CO}_{3}\right) \mathrm{F}$, стронцианит $\mathrm{SrCO}_{3}$ и, вероятно, дациншанит $(\mathrm{Ce})(\mathrm{Sr}, \mathrm{Ca}, \mathrm{Ba})_{3}(\mathrm{Ce}, \mathrm{La})\left(\mathrm{PO}_{4}\right)\left(\mathrm{CO}_{3}\right)_{3-x}(\mathrm{OH}, \mathrm{F})_{x}$. Судя по содержанию фтора, основу концентрата составляет гидроксил-бастнезит. Полагали, что бастнезит и большинство акцессорных минералов (исключение - кварц) будут взаимодействовать с низкоконцентрированными растворами минеральных кислот, что позволит использовать метод сорбционной конверсии для переработки концентрата.

По гранулометрическому составу концентрата $(2,5 \%$ крупностью $+0,1$ мм, $27,9 \%$ крупностью $+0,07$ мм, 15,8 \% крупностью $+0,04$ мм, 53,8 \% крупностью $-0,04$ мм) полагали, что дополнительное измельчение не потребуется.

Условия проведения опытов: среды - 1-2 мас. \% $\mathrm{H}_{2} \mathrm{SO}_{4}, 2,0-2,5$ мас. \% $\mathrm{HNO}_{3}$; расход сорбента КУ-2-8чС в $\mathrm{H}^{+}$-форме $125-450 \%$ от стехиометрически необходимого для сорбции катионов $\mathrm{Me}^{n+}$ бастнезитового концентрата (11-40 мл набухшего сорбента на 1 г концентрата); отношение объёма кислотного раствора к массе концентрата Ж : $\mathrm{T}=50$. Количество $\mathrm{H}_{2} \mathrm{SO}_{4}$ составляло 96-128 \% от стехиометрически необходимого для сульфатизации редкоземельных и щелочноземельных элементов, $\mathrm{HNO}_{3}-100-125 \%$. Как и следовало ожидать, увеличение расхода кислоты на эффективность разложения бастнезитового концентрата не влияло.

Предварительными опытами показано, что, хотя при $20{ }^{\circ} \mathrm{C}$ переработка бастнезитового концентрата принципиально возможна, повышение температуры до $80{ }^{\circ} \mathrm{C}$ повышает степень его разложения раствором 2 мас. \% $\mathrm{H}_{2} \mathrm{SO}_{4}$ в $1,4-1,45$ раза, а раствором 2,5 мас. $\% \mathrm{HNO}_{3}$ - в 2,2 раза. Поэтому процесс проводили при температуре $80{ }^{\circ} \mathrm{C}$. Продолжительность обработки 4 ч оказалась недостаточной и была увеличена до 6 ч.

Выделение углекислого газа не вызывало пенообразования, так как разложение концентрата низкоконцентрированными кислотными растворами проходило постепенно, поэтому не было необходимости в предварительной прокалке.

Степень перехода РЗЭ в сорбент несколько превосходила убыль массы при разложении концентрата. Это определялось тем, что в бастнезитовом концентрате в малом количестве присутствуют трудноразлагающиеся, не содержащие РЗЭ примесные минералы. Поэтому ориентировочная оценка эффективности режимов разложения концентрата возможна по величине убыли массы. 
Извлечение катионов в сорбент при некоторых режимах сернокислотной и азотнокислотной переработки представлено в табл. 2, составы маточных растворов - в табл. 3 .

Таблийа 2

Извлечение катионов в сорбент

при разложении бастнезитового концентрата кислотными растворами

\begin{tabular}{|c|c|c|c|c|c|c|}
\hline \multirow{2}{*}{ Опыт } & \multicolumn{7}{|c|}{ Извлечение, \% } \\
\cline { 2 - 7 } & $\mathrm{Na}$ & $\mathrm{K}$ & $\mathrm{Mg}$ & $\mathrm{Ca}$ & $\mathrm{Sr}$ & $\mathrm{Ba}$ \\
\hline 1 & 91,8 & 98,0 & 93,8 & 97,3 & 97,3 & 99,2 \\
\hline 2 & 82,1 & 98,8 & 80,2 & 98,7 & 99,3 & $\mathrm{H}, \mathrm{o}$, \\
\hline 3 & 85,8 & 97,2 & 92,9 & 96,4 & 96,6 & 99,4 \\
\hline 4 & 89,1 & 83,3 & 88,4 & 88,9 & 90,0 & 98,3 \\
\hline & $\mathrm{Al}$ & $\sum \mathrm{Tr}$ & $\mathrm{Mn}$ & $\mathrm{Fe}$ & $\mathrm{Th}$ & $\mathrm{U}$ \\
\hline 1 & 62,2 & 89,6 & 98,7 & 97,6 & 89,8 & 96,2 \\
\hline 2 & 43,3 & 75,6 & 83,7 & 79,5 & 99,0 & 76,9 \\
\hline 3 & 59,7 & 98,9 & 98,1 & 97,4 & 98,1 & 95,2 \\
\hline 4 & 52,7 & 80,5 & 96,0 & 91,2 & 85,2 & 90,5 \\
\hline
\end{tabular}

Примечание. $1-1,5$ мас. $\% \mathrm{H}_{2} \mathrm{SO}_{4} ; 2-2$ мас. \% $\mathrm{H}_{2} \mathrm{SO}_{4} ; 3-2,5$ мас. \% $\mathrm{HNO}_{3}$; $4-2,5$ мас. $\% \mathrm{HNO}_{3}+15 \Gamma \cdot \pi^{-1} \mathrm{~F}+7,5 \Gamma \cdot \pi^{-1} \mathrm{H}_{3} \mathrm{PO}_{4}$.

Таблий 3

Концентрация в маточных растворах металлов, фосфора и фтора

\begin{tabular}{|c|c|c|c|c|c|c|c|}
\hline \multirow{2}{*}{ Опыт } & \multicolumn{7}{|c|}{ Концентация, пг $^{-1}$} \\
\cline { 2 - 8 } & $\mathrm{Na}_{2} \mathrm{O}$ & $\mathrm{K}_{2} \mathrm{O}$ & $\mathrm{MgO}$ & $\mathrm{CaO}$ & $\mathrm{SrO}$ & $\mathrm{BaO}$ & $\mathrm{Al}_{2} \mathrm{O}_{3}$ \\
\hline 1 & 11,7 & 2,9 & 2,5 & 14,5 & 15,6 & 1,3 & 3,8 \\
\hline 2 & 16,4 & 2,2 & 2,6 & 11,4 & $\mathrm{H} . \mathrm{a}$. & H. a. & 7,0 \\
\hline 3 & 15,1 & 4,4 & 0,1 & 21,7 & 23,7 & 2,4 & 5,6 \\
\hline 4 & 11,3 & 27 & 5,3 & 58,1 & 60,3 & 6,6 & 8,4 \\
\hline & $\mathrm{Tr}_{2} \mathrm{O}_{3}$ & $\mathrm{MnO}$ & $\mathrm{Fe}_{2} \mathrm{O}_{3}$ & $\mathrm{ThO}_{2}$ & $\mathrm{UO}_{2}$ & $\mathrm{P}_{2} \mathrm{O}_{5}$ & $\mathrm{~F}$ \\
\hline 1 & 1,8 & 0,08 & 0,7 & 0,05 & 0,05 & 136,6 & 500 \\
\hline 2 & 3,2 & 0,12 & 1,7 & 0,25 & 0,16 & H. a. & H. a. \\
\hline 3 & 7,3 & 0,14 & 1,0 & 0,10 & 0,06 & 180,4 & 590 \\
\hline 4 & 7,4 & 0,28 & 6,4 & 0,09 & 0,19 & H. a. & H. a. \\
\hline
\end{tabular}

При сернокислотном процессе раствор, содержавший 1,5 мас. \% $\mathrm{H}_{2} \mathrm{SO}_{4}$, оказался наиболее эффективным: степень разложения бастнезитового концентрата составила 86 \% при извлечении РЗЭ в сорбент 89,6 \%. Степень 
разложения концентрата раствором 2,0 мас. $\% \mathrm{H}_{2} \mathrm{SO}_{4}$ составила $82 \%$, раствором 1,0 мас. $\% \mathrm{H}_{2} \mathrm{SO}_{4}-75 \%$. В пределах точности анализов извлечение отдельных РЗЭ было одинаковым. При разложении раствором 2 мас. \% $\mathrm{H}_{2} \mathrm{SO}_{4}$ снижение расхода сорбента с 300 до $125 \%$ от стехиометрически необходимого уменьшило степень разложения с 82 до $75 \%$. Однако снижение расхода сорбента до 125$160 \%$ позволило увеличить концентрацию РЗЭ в 1 л сорбента с 19,4-22,2 до 40,4-47,1 г, что значительно облегчает их десорбцию.

Содержание в сорбенте $\mathrm{ThO}_{2}$ не превышало $0,005, \mathrm{UO}_{2}$ 0,0006 мас. \%.

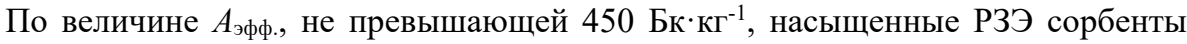
относятся к I классу материалов с повышенным содержанием природных радионуклидов, работа с которыми в производственных условиях может проводиться без ограничений [8].

При использовании азотнокислого раствора концентрацией 2,5 мас. \% степень разложения концентрата составляла $98 \%$ при расходе сорбента $450 \%$ и 89 \% при расходе сорбента $160 \%$ от стехиометрически необходимого.

Неразложившиеся остатки по сравнению с исходным бастнезитовым концентратом обеднены рядом компонентов, особенно кальцием, стронцием и торием, и немного обогащены фосфором (содержание $\mathrm{P}_{2} \mathrm{O}_{5}$ в остатках 1,321,45 мас. \%). Рентгенофазовый анализ показал наличие в остатках монацита, не вскрывающегося низкоконцентрированными кислотами. Судя по количеству РЗЭ и фосфора, остаток опыта 3 бастнезит практически не содержал. Количество фтора в остатках сернокислотного разложения пропорционально количеству РЗЭ, что указывает на присутствие в них неразложившегося бастнезита. Остаток опыта 3 , содержавший лишь 34,4 мас. $\% \sum \operatorname{Tr}_{2} \mathrm{O}_{3}$, немного обогащён ураном и фтором, что может указывать на присутствие в бастнезитовом концентрате небольшого количества трудноразлагающегося акцессорного минерала, содержащего уран и фтор.

Сорбция РЗЭ и большинства примесных катионов проходила очень эффективно, определяя их низкую остаточную концентрацию в маточных растворах. Следует отметить высокую степень поглощения сорбентом бария и

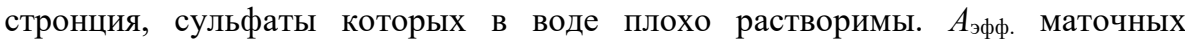
растворов не превышает 3 Бк'кг-1. Низкое содержание металлов в маточном растворе (табл. 3) показывает, что сорбция не лимитирует эффективность процесса, поэтому значительное увеличение расхода сорбента мало влияло на степень разложения бастнезитового концентрата. 
С использованием экспериментальных данных по уравнению

$$
K_{d}=\frac{m_{\mathrm{c}} \cdot V_{\mathrm{p}}}{m_{\mathrm{p}} \cdot V_{\mathrm{c}}},
$$

где $m_{c}$ и $m_{p}$ - масса компонентов в полученных сорбенте и растворе; $V_{\text {с }}$ - объём сорбента; $V_{\mathrm{p}}-$ объём раствора, рассчитали величины коэффициентов распределения $K_{d}$ при сорбционной конверсии концентрата в сернокислой и азотнокислой средах (табл. 4).

Таблий 4

Величины $K_{d}$ при сорбционной конверсии бастнезитового концентрата в сернокислой и азотнокислой средах

\begin{tabular}{|c|c|r|r|r|r|r|r|r|r|r|r|}
\hline \multirow{2}{*}{ Опыт } & \multicolumn{10}{|c|}{$K_{d}$} \\
\cline { 2 - 14 } & $\mathrm{Na}$ & \multicolumn{1}{|c|}{$\mathrm{K}$} & $\mathrm{Mg}$ & $\mathrm{Ca}$ & $\mathrm{Sr}$ & $\mathrm{Ba}$ & $\mathrm{Al}$ & $\mathrm{Fe}$ & $\mathrm{Th}$ & $\mathrm{U}$ & $\sum \mathrm{Tr}$ \\
\hline 1 & 29,9 & 114 & 42,2 & 95 & 102 & 735 & 4,5 & 260 & 824 & 103 & 12900 \\
\hline 2 & 19,1 & 147 & 32,9 & 123 & - & - & 1,7 & 89 & 191 & 18,3 & 6190 \\
\hline 3 & 14,4 & 49 & 21,6 & 42 & 44 & 262 & 2,0 & 113 & 284 & 53 & 2350 \\
\hline 4 & 19,8 & 6,9 & 12,5 & 14 & 16 & 94 & 3,7 & 17 & 309 & 17 & 1880 \\
\hline
\end{tabular}

Из данных табл. 4 видно, что из не содержащих повышенные концентрации фтора и фосфора сернокислых и азотнокислых растворов эффективность сорбции, как правило, характеризуется рядом: $\mathrm{Tr}>>\mathrm{Th} \approx \mathrm{Ba}>\mathrm{Fe}>\mathrm{Sr} \approx \mathrm{U} \approx \mathrm{Ca} \approx \mathrm{K}>\mathrm{Mg}>\mathrm{Na}>\mathrm{Al}$. Минимальное значение $K_{d}$ алюминия, являющегося сильным акцептором фтора, указывает на частичное образование им фторсодержащих анионных комплексов.

Снижение $C_{\mathrm{H}_{2} \mathrm{SO}_{4}}$ с 2 до 1,5 мас. \% способствовало увеличению $K_{d}$ Р3Э и, как следствие, увеличению степени разложения бастнезита (опыты 1 и 2). Одновременно увеличились $K_{d}$ многих металлов, кроме кальция и стронция.

В растворе 2,5 мас. $\% \mathrm{HNO}_{3}$ величины $K_{d}$ щелочных, щелочноземельных и редкоземельных металлов меньше, чем в растворе 2 мас. $\% \mathrm{H}_{2} \mathrm{SO}_{4}$, что определяется повышенной концентрацией, равной соответственно $\approx 0,4$ и $0,3 \mathrm{M}$. Накопление в азотнокислом растворе $\mathrm{H}_{3} \mathrm{PO}_{4}$ и фтор-иона (опыт 4) снижало $K_{d}$ многих элементов, особенно железа и урана, из-за частичного образования этими элементами трудносорбирующихся фторидных (фторфосфатных) комплексов.

Найдено, что в сходных условиях эффективность разложения бастнезитового концентрата азотной и хлористоводородной кислотами была одинаковой. 
Из данных табл. 3 следует, что имеющимися в растворе катионами нейтрализовано лишь 0,3 отн. \% содержащейся в растворе $\mathrm{H}_{2} \mathrm{SO}_{4}$ и 0,6 отн. \% $\mathrm{HNO}_{3}$. Таким образом, содержание металлов в маточных растворах мало и практически не приводит к снижению концентрации используемых для разложения кислот. Однако в растворы попадают фтор и фосфор бастнезитового концентрата: при использованном отношении $\mathrm{T}:$ Ж $=1: 50$ за один цикл концентрация в маточном растворе максимально может достигать $\left(\Gamma^{-1} \pi^{-1}\right)$ 0,204 $\mathrm{P}_{2} \mathrm{O}_{5}$ и 0,610 фтора. Накапливаясь в маточном растворе, фтор и фосфор должны препятствовать разложению бастнезита, ограничивая возможность использования кислотных растворов в обороте.

С целью выяснения возможности повторного использования кислотных растворов исследовали влияние на эффективность разложения бастнезитового концентрата накопления фтора и фосфора в кислотных

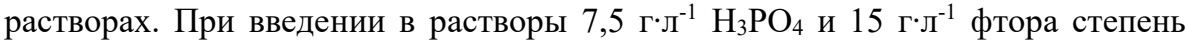
разложения бастнезитового концентрата составила $83 \%$ для раствора 2,5 мас. $\% \mathrm{HNO}_{3}$ и $75 \%$ для раствора 2,0 мас. \% $\mathrm{HNO}_{3}$. Степень разложения бастнезитового концентрата раствором, содержавшим 2 мас. $\% \mathrm{H}_{2} \mathrm{SO}_{4}, 15 \Gamma^{\circ} \pi^{-1}$ фтора и 7,5 $\Gamma^{\circ} \pi^{-1} \mathrm{H}_{3} \mathrm{PO}_{4}$, при $80{ }^{\circ} \mathrm{C}$ равнялась лишь $30 \%$, а при $95{ }^{\circ} \mathrm{C}-50 \%$. Затруднение разложения бастнезитового концентрата при накоплении фтора в сернокислом растворе, вероятно, связано со снижением кислотности раствора из-за образования по мере накопления фтора фторсульфоновой кислоты [10].

При обработке полученных остатков раствором 2 мас. \% $\mathrm{H}_{2} \mathrm{SO}_{4}$, содержавшим $10 \Gamma^{\circ} \pi^{-1} \mathrm{HF}$, убыль массы составила $56 \%$, т. е. была ненамного меньше, чем получавшаяся в тех же условиях при переработке исходного бастнезитового концентрата (61 \%). Небольшое снижение степени разложения при переработке остатков по сравнению с исходным бастнезитовым концентратом связано с увеличением содержания в них трудноразлагаемых акцессорных минералов.

При переработке бастнезитового концентрата исследованного состава и используемого отношения объёма кислотного раствора к массе концентрата содержание фтора $15 \Gamma^{-1}{ }^{-1}$ достигается за $\approx 25$ циклов в обороте, при этом содержание фосфора не превышает $5 \Gamma^{\circ} \pi^{-1}$. Следовательно, многократное использование кислотного раствора позволяет уменьшить расход кислот до $\leq 5$ $\%$ от стехиометрически необходимого.

\section{Выводы}

1. Предложен ресурсо- и энергосберегающий метод разложения бастнезитового концентрата, основанный на его взаимодействии в присутствии сульфокатионита в водородной форме с низкоконцентрированными растворами минеральных кислот: серной $(\leq 2$ мас. \%), азотной $(\leq 2,5$ мас. \%). В процессе 
взаимодействия катионы поглощаются сорбентом, а фтор и часть фосфора кислотным раствором.

2. Увеличение температуры процесса с 20 до $80{ }^{\circ} \mathrm{C}$ увеличивает скорость разложения. Серно- и азотнокислотное разложение бастнезитового концентрата при $80{ }^{\circ} \mathrm{C}$ достигается при расходе сорбента $125-160 \%$ от стехиометрически необходимого (11-14 $\mathrm{m}^{3}$ на 1 т концентрата), при этом концентрация суммы оксидов РЗЭ в сорбенте превышает $40 \Gamma^{-} \pi^{-1}$.

3. Найдено, что радиоактивность сорбента и раствора соответствует I классу материалов, содержащих природные радионуклиды, что позволяет работать с ними в производственных условиях без ограничений.

4. Показана возможность использования в обороте маточных растворов с накоплением в них фтора до концентрации 10-15 $\Gamma^{\cdot} \pi^{-1}$. Это позволяет сократить количество подлежащих утилизации отходов.

5. Из маточных растворов фтор осаждается нейтрализацией карбонатом кальция, что позволяет ещё более уменьшить расход минеральных кислот и количество требующих утилизации отходов. При этом эффективность выделения фтора из азотнокислых растворов значительно выше, чем из сернокислых.

\section{2. Разложение иттрофлюоритового концентрата}

В Мурманской области (Россия) имеется малое месторождение иттрофлюорита, представляющего собой твёрдый раствор фторидов, главным образом РЗЭ и кальция. Высокое содержание в сумме РЗЭ элементов иттриевой группы (табл. 5) определяет интерес к использованию этого сырья.

Таблица 5

Соотношение индивидуальных РЗЭ в сумме РЗЭ иттрофлюорита

\begin{tabular}{|c|c|c|c|c|c|c|c|}
\hline $\mathrm{Y}_{2} \mathrm{O}_{3}$ & $\mathrm{La}_{2} \mathrm{O}_{3}$ & $\mathrm{Ce}_{2} \mathrm{O}_{3}$ & $\mathrm{Pr}_{2} \mathrm{O}_{3}$ & $\mathrm{Nd}_{2} \mathrm{O}_{3}$ & $\mathrm{Sm}_{2} \mathrm{O}_{3}$ & $\mathrm{Eu}_{2} \mathrm{O}_{3}$ & $\mathrm{Gd}_{2} \mathrm{O}_{3}$ \\
\hline 57,05 & 3,92 & 8,63 & 0,86 & 2,59 & 0,77 & 0,10 & 1,11 \\
\hline $\mathrm{Tb}_{2} \mathrm{O}_{3}$ & $\mathrm{Dy}_{2} \mathrm{O}_{3}$ & $\mathrm{Ho}_{2} \mathrm{O}_{3}$ & $\mathrm{Er}_{2} \mathrm{O}_{3}$ & $\mathrm{Tm}_{2} \mathrm{O}_{3}$ & $\mathrm{Yb}_{2} \mathrm{O}_{3}$ & $\mathrm{Lu}_{2} \mathrm{O}_{3}$ & $\sum \mathrm{Tr}_{2} \mathrm{O}_{3}$ \\
\hline 0,30 & 3,20 & 0,94 & 4,97 & 1,15 & 13,15 & 1,26 & 100,00 \\
\hline
\end{tabular}

В работе использовали иттрофлюоритовый концентрат ручной разборки, сульфокатионит КУ-2-8чС в $\mathrm{H}^{+}$-форме азотную и фтористоводородную кислоты.

Состав иттрофлюоритового концентрата (в пересчёте на оксиды) приведён в табл. 6. Видно, что кроме РЗЭ и кальция он содержит значительное количество кремния. По сравнению с бастнезитом иттрофлюорит 
характеризуется значительно более высоким содержанием фтора (40 мас. \%). Из соотношения концентраций катионов и фтора следует, что кроме иттрофлюорита концентрат содержит акцессорные оксидные минералы. $A_{\text {эфф. }}$ концентрата составляла $\approx 5,2$ КБк $\kappa^{-1}$, т. е. по содержанию природных радионуклидов, главным образом тория, он относится к IV классу материалов с повышенным содержанием природных радионуклидов [8].

Таблий 6

Содержание основных компонентов в иттрофлюоритовом концентрате

\begin{tabular}{|c|c|c|c|c|c|c|c|c|c|c|}
\hline \multicolumn{11}{|c|}{ Состав, мас. \% } \\
\hline $\mathrm{Y}_{2} \mathrm{O}_{3}$ & & $\mathrm{La}_{2} \mathrm{O}_{3}$ & $\mathrm{Ce}_{2} \mathrm{O}_{3}$ & & $\mathrm{Pr}_{2} \mathrm{O}_{3}$ & \multicolumn{2}{|c|}{$\mathrm{Nd}_{2} \mathrm{O}_{3}$} & $\mathrm{Sm}_{2} \mathrm{O}_{3}$ & $\mathrm{Eu}_{2} \mathrm{O}_{3}$ & $\mathrm{Gd}_{2} \mathrm{O}_{3}$ \\
\hline 8,51 & & 0,585 & 1,287 & & 0,128 & \multicolumn{2}{|c|}{0,387} & 0,1156 & & 0,1652 \\
\hline $\mathrm{Tb}_{2} \mathrm{O}$ & & $\mathrm{Dy}_{2} \mathrm{O}_{3}$ & $\mathrm{Ho}_{2} \mathrm{O}_{3}$ & & $\mathrm{Er}_{2} \mathrm{O}_{3}$ & \multicolumn{2}{|c|}{$\mathrm{Tm}_{2} \mathrm{O}_{3}$} & $\mathrm{Yb}_{2} \mathrm{O}_{3}$ & $\mathrm{Lu}_{2} \mathrm{O}_{3}$ & $\sum \mathrm{Tr}_{2} \mathrm{O}_{3}$ \\
\hline 0,044 & & 0,4775 & 0,1398 & & 0,7412 & \multicolumn{2}{|c|}{0,1713} & 1,962 & 0,1887 & 13,15 \\
\hline $\mathrm{Na}_{2} \mathrm{O}$ & \multicolumn{2}{|c|}{\begin{tabular}{l|l|}
$\mathrm{K}_{2} \mathrm{O}$ & $\mathrm{MgO}$ \\
\end{tabular}} & $\mathrm{CaO}$ & $\mathrm{Al}_{2} \mathrm{O}_{3}$ & \begin{tabular}{|l|l|}
$\mathrm{T}_{3}$ & $\mathrm{TiO}_{2}$ \\
\end{tabular} & \multicolumn{2}{|l|}{$\mathrm{Fe}_{2} \mathrm{O}_{3}$} & $2 \mathrm{Nb}_{2} \mathrm{O}_{5}$ & \begin{tabular}{|l|l|}
$\mathrm{ThO}_{2}$ & $\mathrm{UO}$ \\
\end{tabular} & $\mathrm{F}$ \\
\hline 1,15 & \multicolumn{2}{|c|}{\begin{tabular}{l|l}
0,051 & 0,030 \\
\end{tabular}} & 66,4 & 0,373 & \begin{tabular}{l|l}
3 & 0,099 \\
\end{tabular} & 0,414 & 6,49 & 0,0041 & \multicolumn{2}{|c|}{\begin{tabular}{|l|l|l|}
0,159 & 0,0017 & 40,0 \\
\end{tabular}} \\
\hline \multicolumn{11}{|c|}{ Состав, г-экв. в 1000 г концентрата } \\
\hline $\mathrm{Na}^{+}$ & & $\mathrm{K}^{+}$ & $\mathrm{g}^{2+}$ & $\mathrm{Ca}^{2+}$ & & & $\mathrm{Ti}^{4+}$ & $\mathrm{Fe}^{3+}$ & $\sum \operatorname{Tr}^{3+}$ & Всего \\
\hline 0,37 & & 0,01 & 0,02 & 23, & 7 & & 0,05 & 0,16 & 3,43 & 27,96 \\
\hline
\end{tabular}

Гранулометрический состав концентрата: 20,0 \% класса крупности $+0,25$ мм, 21,75 \% класса $0,25+0,14$ мм, 31,25\% класса $-0,14+0,07$ мм и 27,0 \% класса $-0,07$ мм. В ряде опытов концентрат дополнительно измельчался до 100 $\%$ класса крупности $-0,07$ мм.

Исследовали эффективность сорбционной конверсии иттрофлюоритового концентрата в растворах 2,0-2,5 мас. \% $\mathrm{HNO}_{3}$ и 1 мас. \% HF. Поисковый опыт показал, что принципиально возможно использование раствора, содержащего 1 мас. \% $\mathrm{HNO}_{3}$, но при равных условиях скорость разложения концентрата была в два раза меньше, чем при использовании раствора с 2,5 мас. \% $\mathrm{HNO}_{3}$.

Величина Ж : Т во всех опытах равнялась 40. Расход сорбента варьировался от 93-265\% от стехиометрически необходимого количества. Достаточно большая величина Ж : $\mathrm{T}$ определялась необходимостью гарантированного помещения сорбента в раствор. Она может быть значительно уменьшена при практическом использовании метода. В отдельных опытах степень разложения концентрата ориентировочно оценивали по величине массы твёрдого остатка.

В низкоконцентрированных растворах азотной кислоты иттрофлюорит растворяется, хотя и не в значительной степени, по реакциям: 


$$
\begin{aligned}
& \mathrm{CaF}_{2}+2 \mathrm{HNO}_{3} \leftrightarrow \mathrm{Ca}\left(\mathrm{NO}_{3}\right)_{2}+2 \mathrm{HF} \\
& \mathrm{TrF}_{3}+3 \mathrm{HNO}_{3} \leftrightarrow \operatorname{Tr}\left(\mathrm{NO}_{3}\right)_{3}+3 \mathrm{HF} .
\end{aligned}
$$

Достигавшаяся, несмотря на накопление фтора в растворе, высокая степень разложения концентрата позволила предположить принципиальную возможность использования низкоконцентрированной фтористоводородной кислоты в качестве кислотного раствора.

Механизм растворения фторидов кальция и РЗЭ в растворах HF неясен, но, как следует из приводимых ниже результатов, в этих растворах кальций и РЗЭ присутствуют, по крайней мере частично, в виде катионных комплексов, поскольку они количественно сорбировались сульфокатионитом.

Определили при 20 и $80{ }^{\circ} \mathrm{C}$ растворимость фторида кальция в растворах 1-3 мас. \% азотной и в растворах 1-2 мас. \% фтористоводородной кислот (табл. 7).

Таблииа 7

Растворимость $\mathrm{CaF}_{2}$ в низкоконцентрированных растворах $\mathrm{HNO}_{3}$ и $\mathrm{HF}$

\begin{tabular}{|c|c|c|c|c|c|c|c|}
\hline \multicolumn{8}{|c|}{ Растворимость $\left(\Gamma^{\circ} \pi^{-1}\right)$ при температуре } \\
\hline \multicolumn{7}{|c|}{$20{ }^{\circ} \mathrm{C}$} & \multicolumn{5}{c|}{$80{ }^{\circ} \mathrm{C}$} \\
\hline$C_{\mathrm{HNO}_{3}}$ & $C_{\mathrm{CaF}_{2}}$ & $C_{\mathrm{HF}}$ & $C_{\mathrm{CaF}_{2}}$ & $C_{\mathrm{HNO}_{3}}$ & $C_{\mathrm{CaF}_{2}}$ & $C_{\mathrm{HF}}$ & $C_{\mathrm{CaF}_{2}}$ \\
\hline 1,0 & 0,09 & 1,0 & 0,028 & 1,0 & 0,34 & 1,0 & 0,0028 \\
\hline 2,0 & 0,33 & 1,5 & 0,014 & 2,0 & 0,66 & 1,5 & 0,0042 \\
\hline 3,0 & 0,37 & 2,0 & 0,007 & 3,0 & 0,86 & 2,0 & 0,0098 \\
\hline
\end{tabular}

Примечание. $C_{\mathrm{HNO}_{3}}$ и $C_{\mathrm{HF}}-$ концентрации кислот в растворах, мас. \%.

Из данных табл. 7 следует, что уже при комнатной температуре введение в раствор небольших концентраций $\mathrm{HNO}_{3}$ значительно увеличивает растворимость $\mathrm{CaF}_{2}$, равную в воде $0,02 \Gamma^{\cdot} \pi^{-1}$ [11]. Повышение температуры, особенно при использовании раствора с $C_{\mathrm{HNO}_{3}} \approx 1$ мас. \%, ещё более увеличивает растворимость.

Растворимость $\mathrm{CaF}_{2}$ в растворах $\mathrm{HF}$ мала, но она выше рассчитанной в предположении, что вводимый фтор-ион будет высаливать $\mathrm{CaF}_{2}$. При температуре $20{ }^{\circ} \mathrm{C}$ с увеличением концентрации $\mathrm{HF}$ растворимость $\mathrm{CaF}_{2}$ снижалась при температуре $20^{\circ} \mathrm{C}$ и увеличивалась при $80{ }^{\circ} \mathrm{C}$.

Данные о растворимости фторидов РЗЭ в растворах азотной кислоты очень ограничены. В кислых растворах растворимость фторидов РЗЭ при увеличении концентрации кислот сначала возрастает, затем, достигнув максимума, уменьшается. Так, в растворах азотной кислоты максимальная растворимость $\mathrm{YF}_{3}$ наблюдалась при концентрации азотной кислоты $\approx 4,5 \mathrm{M}$ и 
составила $1,12 \Gamma^{\cdot} \pi^{-1}\left(23,1\right.$ мг-экв $\left.\cdot \pi^{-1}\right)$ иттрия, $\mathrm{a} \mathrm{LaF}_{3}$ - при концентрации азотной кислоты $\approx 3,3 \mathrm{M}\left(0,42 \Gamma^{\cdot} \pi^{-1}\right.$, или 6,43 мг-экв $\pi^{-1}$, лантана) $[12,13]$.

По мере разложения концентрата содержание фтора в растворе непрерывно возрастало. При выбранном соотношении Ж : Т и полном растворении концентрата оно может достигать $10 \Gamma^{\circ} \pi^{-1}$, что должно затруднять растворение иттрофлюорита. Расчёт с использованием полученных данных по растворимости показал, что при отношении Ж : $\mathrm{T}=40$ после разложения $25 \%$ навески концентрата равновесная концентрация кальция будет не более 0,5 мг ${ }^{-1}$. Однако, как видно из данных табл. 3 , растворимость $\mathrm{CaF}_{2}$ в присутствии 0,5-1,0 моль $\cdot \pi^{-1}\left(9,5-19 \Gamma^{-1} \pi^{-1}\right)$ фтора значительно выше.

Данные о растворимости фторидов трёхвалентных РЗЭ в растворах фтористоводородной кислоты практически отсутствуют. Сообщалось, что при $0{ }^{\circ} \mathrm{C}$

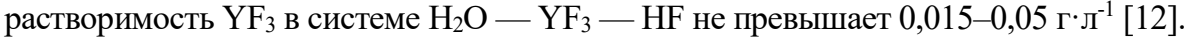

При концентрации $\mathrm{HF}$ 14,99-40,08 мас. \% растворимость $\mathrm{CeF}_{4}$ изменялась в пределах $0,92-8,49 \Gamma^{\cdot} \pi^{-1}$, возрастая при снижении $C_{\mathrm{HF}}$. Найдено, что равновесной твёрдой фазой является $\mathrm{HF} \cdot \mathrm{CeF}_{4}[13]$.

Присутствие $\mathrm{HF}$ в водном растворе увеличивает и растворимость $\mathrm{ThF}_{4}$, которая при комнатной температуре в воде равна лишь $0,17 \mathrm{Mг}^{-1}{ }^{-1}$ [14], но

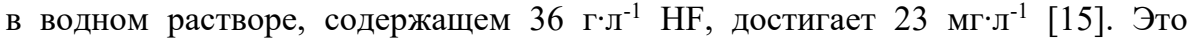
определяет высокую степень перехода тория в сорбент.

Таким образом, фтористоводородная кислота не только не снижает растворимость малорастворимых фторидов, но и приводит к некоторому увеличению их растворимости. Это позволяло надеяться на возможность эффективного протекания сорбционной конверсии иттрофлюоритового концентрата в растворах указанного состава.

В таблице 8 обобщены данные по условиям и результатам проведенных экспериментов, а в табл. 9 приведены данные по распределению металлов между продуктами переработки: твёрдым остатком, раствором и сорбентом опыта 4.

Таблийа 8

Условия и результаты опытов по разложению иттрофлюоритового концентрата

\begin{tabular}{|c|c|c|c|c|c|c|}
\hline \multirow[b]{2}{*}{$\begin{array}{c}\text { № } \\
\Pi / \Pi\end{array}$} & \multicolumn{3}{|c|}{ Исходный раствор } & \multirow[b]{2}{*}{$\begin{array}{c}\text { Время, } \\
\text { ч }\end{array}$} & \multirow[b]{2}{*}{$t,{ }^{\circ} \mathrm{C}$} & \multirow[b]{2}{*}{$\begin{array}{l}\text { Убыль } \\
\text { массы, } \\
\text { отн. \% }\end{array}$} \\
\hline & кислота & $C$, мас. \% & $\begin{array}{c}\text { расход, отн. \% (от } \\
\text { стехиометрического } \\
\text { расхода) }\end{array}$ & & & \\
\hline 1 & 2 & 3 & 4 & 5 & 6 & 7 \\
\hline $1^{*}$ & $\mathrm{HNO}_{3}$ & 2,5 & 58 & 7 & 80 & 66,0 \\
\hline $2^{*}$ & $\mathrm{HNO}_{3}$ & 2,5 & 58 & 7 & 80 & 80,0 \\
\hline $3^{*}$ & $\mathrm{HNO}_{3}$ & 2,0 & 46,5 & 6 & 80 & 72,0 \\
\hline 4 & $\mathrm{HNO}_{3}$ & 2,5 & 58 & 4 & 80 & 94,0 \\
\hline
\end{tabular}


Окончание таблиць 8

\begin{tabular}{|c|c|c|c|c|c|c|c|c|c|}
\hline 1 & 2 & \multicolumn{2}{|c|}{3} & \multicolumn{2}{|l|}{4} & 5 & \multicolumn{2}{|l|}{6} & 7 \\
\hline 5 & $\mathrm{HNO}_{3}$ & \multicolumn{2}{|c|}{2,5} & \multicolumn{2}{|l|}{58} & 6 & \multicolumn{2}{|c|}{80} & 94,0 \\
\hline 6 & $\mathrm{HNO}_{3}$ & \multicolumn{2}{|c|}{2,5} & \multicolumn{2}{|l|}{58} & 6 & \multicolumn{2}{|c|}{80} & 88,0 \\
\hline $7^{*}$ & $\mathrm{HF}$ & \multicolumn{2}{|c|}{1,0} & \multicolumn{2}{|l|}{-} & 4 & \multicolumn{2}{|c|}{20} & 50,0 \\
\hline $8^{*}$ & $\mathrm{HF}$ & \multicolumn{2}{|c|}{1,0} & \multicolumn{2}{|l|}{-} & 4 & \multicolumn{2}{|c|}{80} & 70,0 \\
\hline $9^{*}$ & $\mathrm{HF}$ & & & \multicolumn{2}{|l|}{-} & 8 & \multicolumn{2}{|c|}{80} & 90,0 \\
\hline \multirow[b]{2}{*}{$\begin{array}{l}\text { № } \\
\Pi / \Pi\end{array}$} & \multicolumn{5}{|c|}{ Сорбент } & \multicolumn{4}{|c|}{ Поглощено сорбентом, \% } \\
\hline & форма & $\begin{array}{c}\beta, \\
\text { отн. \% }\end{array}$ & \multicolumn{2}{|c|}{$\begin{array}{c}\text { использование } \\
\text { СОЕ, отн. \% }\end{array}$} & $\begin{array}{c}C_{\Sigma \operatorname{Tr}_{2} \mathrm{O}_{3}}, \\
\Gamma \cdot \pi^{-1}\end{array}$ & $\sum \operatorname{Tr}$ & $\mathrm{Ca}$ & Th & $\mathrm{U}$ \\
\hline $1^{*}$ & $\mathrm{H}^{+}$ & 93 & \multicolumn{2}{|r|}{70,0} & 6,76 & 72,1 & 72,6 & 64,1 & 50,4 \\
\hline $2^{*}$ & $\mathrm{H}^{+}$ & 139 & \multicolumn{2}{|r|}{56,8} & H. a. & H. a. & H. a. & H. a. & H. a. \\
\hline $3^{*}$ & $\mathrm{H}^{+}$ & 200 & \multicolumn{2}{|r|}{35,5} & H. a. & H. a. & H. a. & H. a. & H. a. \\
\hline 4 & $\mathrm{H}^{+}$ & 265 & \multicolumn{2}{|r|}{35,0} & 3,1 & 93,9 & 93,0 & 93,2 & 86,5 \\
\hline 5 & $\mathrm{H}^{+}$ & 265 & \multicolumn{2}{|r|}{35,0} & H. a. & H. a. & H. a. & H. a. & H. a. \\
\hline 6 & $\mathrm{NH}_{4}{ }^{+}$ & 265 & \multicolumn{2}{|r|}{32,8} & H. a. & H. a. & H. a. & H. a. & H. a. \\
\hline $7^{*}$ & $\mathrm{H}^{+}$ & 265 & \multicolumn{2}{|r|}{18,0} & 1,6 & 50,0 & 49,9 & 50,0 & 25,9 \\
\hline $8^{*}$ & $\mathrm{H}^{+}$ & 265 & & 25,3 & 2,3 & 70,0 & 69,9 & 70,0 & 62,3 \\
\hline $9^{*}$ & $\mathrm{H}^{+}$ & 265 & & 32,5 & 3,0 & 89,8 & 89,7 & 89,5 & 76,5 \\
\hline
\end{tabular}

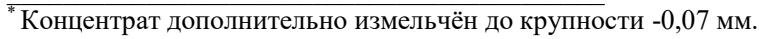

Таблий 9

Распределение металлов между продуктами переработки, полученными в опыте 4

\begin{tabular}{|c|c|c|c|c|c|c|c|c|}
\hline \multirow[t]{2}{*}{ Продукт } & \multicolumn{8}{|c|}{ Распределение, отн. \% } \\
\hline & $\mathrm{Y}$ & $\mathrm{La}$ & $\mathrm{Ce}$ & $\operatorname{Pr}$ & $\mathrm{Nd}$ & $\mathrm{Sm}$ & $\mathrm{Eu}$ & Gd \\
\hline 1 & 93,94 & 93,74 & 93,75 & 93,71 & 93,82 & 93,83 & 94,20 & 93,84 \\
\hline 2 & 6,00 & 6,01 & 5,99 & 6,01 & 5,98 & 6,00 & 5,52 & 6,05 \\
\hline \multirow[t]{2}{*}{3} & 0,06 & 0,25 & 0,26 & 0,28 & 0,20 & 0,17 & 0,28 & 0,11 \\
\hline & $\mathrm{Tb}$ & Dy & Ho & $\mathrm{Er}$ & $\mathrm{Tm}$ & $\mathrm{Yb}$ & $\mathrm{Lu}$ & $\sum \mathrm{Tr}$ \\
\hline 1 & 94,01 & 93,95 & 93,93 & 93,95 & 93,99 & 93,95 & 93,87 & 93,91 \\
\hline 2 & 5,90 & 5,99 & 6,01 & 5,99 & 5,95 & 6,01 & 6,04 & 6,00 \\
\hline \multirow[t]{2}{*}{3} & 0,09 & 0,06 & 0,06 & 0,06 & 0,06 & 0,04 & 0,10 & 0,09 \\
\hline & \multicolumn{2}{|l|}{$\mathrm{Na}$} & $\mathrm{Mg}$ & $\mathrm{Ca}$ & \multicolumn{2}{|l|}{$\mathrm{Sr}$} & 1 & $\mathrm{Ti}$ \\
\hline 1 & \multicolumn{2}{|l|}{64,3} & 38,0 & 92,97 & \multicolumn{2}{|l|}{93,14} & & 71,11 \\
\hline 2 & \multicolumn{2}{|l|}{6,00} & 6,00 & 6,00 & \multicolumn{2}{|l|}{6,00} & & 6,06 \\
\hline \multirow[t]{2}{*}{3} & \multicolumn{2}{|l|}{29,7} & 56,0 & 1,03 & \multicolumn{2}{|l|}{0,86} & 39,46 & 22,83 \\
\hline & \multicolumn{2}{|l|}{$\mathrm{Fe}$} & $\mathrm{SiO}_{2}$ & $\mathrm{Zr}$ & \multicolumn{2}{|l|}{$\mathrm{Nb}$} & Th & $\mathrm{U}$ \\
\hline 1 & \multicolumn{2}{|l|}{92,95} & - & 16,52 & \multicolumn{2}{|l|}{6,73} & 93,18 & 80,70 \\
\hline 2 & \multicolumn{2}{|l|}{5,99} & 92,45 & 5,81 & \multicolumn{2}{|l|}{4,88} & 6,04 & 11,77 \\
\hline 3 & 1,06 & \multicolumn{2}{|c|}{7,55} & 77,67 & 88,39 & \multicolumn{2}{|c|}{0,78} & 7,53 \\
\hline
\end{tabular}

Примечание. 1 - сорбент, 2 - раствор, 3 - твёрдый остаток. 
Из экспериментальных данных видно, что при использовании азотнокислого раствора степень разложения концентрата достигала по крайней мере $94 \%$. Для осуществления процесса достаточен расход $\mathrm{HNO}_{3} 58 \%$ от стехиометрически необходимого для протекания реакций (5) и (6). Степень поглощения сорбентом РЗЭ, кальция и тория практически одинакова. Таким образом, разделения РЗЭ и кальция на стадии разложения концентрата не происходит. Поглощение отдельных РЗЭ отличается в пределах точности анализа. Расход сорбента $265 \%$ от стехиометрически необходимого обеспечивал высокую степень разложения концентрата, при этом степень заполнения его функциональных групп, рассчитанная из допущения, что сорбируются катионы $\mathrm{Me}^{n+}$, составила 35 \%. При таком расходе сорбента увеличение продолжительности процесса с 4 до 6 ч не повышало степень разложения иттрофлюорита.

Более низкая степень поглощения алюминия, титана, циркония и ниобия связана с частичным образованием ими анионных фторидных комплексов. Снижение расхода сорбента приводило к уменьшению степени разложения концентрата, но повышало эффективность его использования, за счет повышения концентрации в сорбенте поглощенных катионов. Таким образом, исследованный метод позволяет эффективно отделять фтор-ион от катионов иттрофлюоритового концентрата. Маточный раствор содержит одновременно азотную и фтористоводородную кислоты, причём содержание HF в маточном растворе может достигать $10 \Gamma^{\cdot} \pi^{-1}$. Возможность его использования в обороте без предварительного осаждения фтора проблематична, однако осаждение фтора, как и в случае регенерации маточных растворов переработки бастнезитового концентрата, легко осуществима.

Как видно из данных табл. 7, растворимость $\mathrm{CaF}_{2}$ в низкоконцентрированных растворах фтористоводородной кислоты при $20{ }^{\circ} \mathrm{C}$ больше, чем при $80{ }^{\circ} \mathrm{C}$. При $20{ }^{\circ} \mathrm{C}$ в течение 4 ч степень разложения иттрофлюорита составила $50 \%$ и возрастала при увеличении продолжительности процесса. Однако при $80{ }^{\circ} \mathrm{C}$ процесс разложения концентрата протекает с большей скоростью. Достигнутая при $80{ }^{\circ} \mathrm{C}$ степень разложения 90 \% достаточно высока и может быть увеличена при оптимизации параметров проведения процесса.

Как и при использовании азотнокислого раствора, поглощение сорбентом РЗЭ, кальция и тория практически одинаково. Получающийся в процессе кислотный маточный раствор содержит только фтористо- и кремнефтористоводородную кислоты, что значительно упрощает его регенерацию. 
Немного более низкая степень поглощения сорбентом урана, возможно, связана с тем, что часть его входит в состав акцессорных минералов, более трудноразлагающихся при использованном методе разложения концентрата.

Азотнокисло-фторидный раствор опыта 4 содержал $\left(\mathrm{M \Gamma}^{\cdot} \pi^{-1}\right)$ : 3,3 $\sum \mathrm{Tr}_{2} \mathrm{O}_{3}, 85,4 \mathrm{Na}_{2} \mathrm{O}, 172 \mathrm{CaO}, 1,5 \mathrm{SrO}, 36,9 \mathrm{Al}_{2} \mathrm{O}_{3}, 5,6 \mathrm{TiO}_{2}, 1,1 \mathrm{Fe}_{2} \mathrm{O}_{3}, 1500$ $\mathrm{SiO}_{2}, 6,0 \mathrm{ZrO}_{2}, 0,31 \mathrm{ThO}_{2}, 0,032 \mathrm{UO}_{2}$ и $9400 \mathrm{~F}$. Раствор был нерадиоактивным, количество фтора примерно в три раза превышало необходимое для связывания во фторидные комплексы фторакцепторных катионов кремния, алюминия,

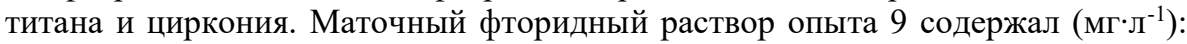
4,3 $\sum \operatorname{Tr}_{2} \mathrm{O}_{3}, 43 \mathrm{CaO}, 0,15 \mathrm{ThO}_{2}, 0,046 \mathrm{UO}_{2}$ и $19000 \mathrm{~F}$.

В получавшихся сорбентах содержалось до $\left(\Gamma^{\cdot} \pi^{-1}\right): 6,6 \sum \mathrm{Tr}, 0,33 \mathrm{Na}$, 24,6 Ca, 0,29 Sr, 0,04 Al, 0,012 Ti, 0,19 Fe, 0,064 Th, 5,2 $\cdot 10^{-4} \mathrm{U}$, небольшие концентрации некоторых других примесей. Снижение расхода сорбента приводило к значительному увеличению концентрации компонентов в сорбенте, что упрощает проведение десорбции и последующее извлечение целевых продуктов из элюата. Наблюдаемое при этом уменьшение степени разложения концентрата не является критическим, так как неразложившийся остаток может быть направлен в оборот.

В таблице 10 приведены величины $K_{d}$ при сорбционной конверсии иттрофлюоритового концентрата в растворах азотной и фтористоводородной кислот (нумерация опытов в табл. 10 соответствует нумерации в табл. 9).

Таблица 10

Величины $K_{d}$ при сорбционной конверсии иттрофлюоритового концентрата в растворах азотной и фтористоводородной кислот

\begin{tabular}{|c|c|c|c|r|c|c|c|c|c|c|r|}
\hline \multirow{2}{*}{ Опыт } & \multicolumn{10}{|c|}{$K_{d}$} \\
\cline { 2 - 13 } & $\mathrm{Na}$ & $\mathrm{K}$ & $\mathrm{Mg}$ & $\mathrm{Ca}$ & $\mathrm{Sr}$ & $\mathrm{Al}$ & $\mathrm{Fe}$ & $\mathrm{Ti}$ & $\mathrm{Th}$ & $\mathrm{U}$ & $\sum \mathrm{Tr}$ \\
\hline 4 & 2,2 & 0,01 & 0,68 & 90 & 109 & 1,4 & 87,4 & 3,1 & 120 & 10,9 & 1063 \\
\hline 7 & H. a. & H. a. & H. a. & 473 & H. a. & H. a. & H. a. & H. a. & 200 & 10,7 & 1217 \\
\hline 9 & H. a. & H. a. & H. a. & 277 & H. a. & H. a. & H. a. & H. a. & 190 & 6,1 & 550 \\
\hline
\end{tabular}

Увеличение концентрации фтора в растворе 2,5 мас. \% $\mathrm{HNO}_{3}$ затрудняет сорбцию РЗЭ, тория, урана и особенно щелочных элементов и магния, но улучшается сорбция кальция и стронция. Вероятно, что снижение эффективности сорбции щелочных элементов и магния определяется образованием ими малорастворимых, труднодиссоциирующих фторсиликатных комплексов.

Достоинствами предлагаемого метода разложения иттрофлюорита являются низкие концентрация и расход азотной кислоты, а при использовании 
фтористоводородной кислоты - исключение её расхода, что упрощает утилизацию маточных растворов. Низкая температура процесса позволяет использовать негерметичную аппаратуру, изготовленную из коррозионностойких пластмасс (полипропилен, фторопласт). Возможно проведение процесса при комнатной температуре с резким снижением энергозатрат.

В заключение отметим, что предложенный метод принципиально применим и для разложения плавикового шпата, при этом может быть исключено образование фторогипса.

\section{Выводы}

1. Установлена возможность эффективного разложения иттрофлюоритового концентрата путём его сорбционной конверсии в среде азотной кислоты концентрацией $\leq 2,5$ мас. $\%$ и в среде 1 мас. \% фтористоводородной кислоты. При использовании фтористоводородной кислоты она дополнительно получается при разложении концентрата.

2. В растворе 1 мас. \% фтористоводородной кислоты РЗЭ и торий существуют в виде катионных комплексов.

3. Расход азотной кислоты составляет $\leq 58 \%$ от стехиометрически необходимого для полного растворения концентрата, из получающегося маточного раствора возможно осаждение фтора с регенерацией азотнокислого раствора.

4. Таким образом, в процессе сокращаются расход реагентов и количество образующихся отходов, предотвращается переход фтора в газовую фазу.

5. Судя по содержанию урана и тория, по радиоактивности сорбент и раствор соответствуют I классу материалов, содержащих природные радионуклиды, что позволяет работать с ними в производственных условиях без ограничений. 


\section{3. ИССЛЕДОВАНИЕ РАЗЛОЖЕНИЯ МЕТОДОМ СОРБЦИОННОЙ КОНВЕРСИИ ФОСФАТНОГО РЕДКОЗЕМЕЛЬНОГО СЫРЬЯ}

\section{1. Разложение монацитового концентрата}

Монацитовые концентраты являются ценным сырьевым источником Р3Э и тория. Для гидрохимического вскрытия монацитового концентрата первым был применён сернокислотный метод. В различных вариантах процесса извлекали либо РЗЭ цериевой группы с отделением от основной части тория, либо все РЗЭ и торий. В таком процессе утилизация сернокисло-фосфатного раствора затруднена [3].

Более эффективен щелочной метод, при котором обработку монацитового концентрата осуществляют нагретым до $120-140{ }^{\circ} \mathrm{C}$ раствором $\mathrm{NaOH}$ концентрацией 60-70 мас. \%. Предложено использовать заполненный стальными шарами автоклав, в котором совмещается измельчение и выщелачивание монацита $[16,17]$. При этом образующиеся, препятствующие взаимодействию нерастворимые гидроксиды РЗЭ постоянно удаляются с поверхности зёрен монацита, что обеспечивает высокую степень протекания реакции. Оптимальные условия здесь: 1 ч при $175{ }^{\circ} \mathrm{C}$ или 2,5 ч при $150{ }^{\circ} \mathrm{C}$, концентрация раствора $\mathrm{NaOH}-500 \Gamma^{\cdot} \pi^{-1}$, расход $\mathrm{NaOH}-150 \%$ от стехиометрически необходимого. Из полученного после высокотемпературной щелочной обработки продукта сначала горячей водой выщелачивают $\mathrm{Na}_{3} \mathrm{PO}_{4}$ и избыточный $\mathrm{NaOH}$.

Для извлечения из гидроксидного кека РЗЭ с отделением урана и тория в отдельные продукты предложен ряд решений, в которых осуществляется выщелачивание кека $\mathrm{HCl}, \mathrm{HNO}_{3}$ или $\mathrm{H}_{2} \mathrm{SO}_{4}$. Из сернокислых растворов возможно осаждение двойных сульфатов натрия и РЗЭ. При нейтрализации соляно- и азотнокислых растворов карбонатом натрия осаждают карбонаты РЗЭ с удержанием тория и урана в растворе в виде их двойных карбонатов с натрием. Пероксидные комплексы тория и урана могут быть осаждены введением $\mathrm{H}_{2} \mathrm{O}_{2}$, при этом РЗЭ остаются в растворе. Введением щавелевой кислоты возможно осаждение оксалатов РЗЭ и тория, при этом уран остаётся в растворе в виде $\mathrm{UO}_{2}\left(\mathrm{C}_{2} \mathrm{O}_{4}\right)$, откуда может быть выделен в виде $\left(\mathrm{NH}_{4}\right)_{2} \mathrm{U}_{2} \mathrm{O}_{7}$. Из остатка оксалатов РЗЭ и тория последний может быть выщелочен смешанным раствором $\mathrm{Na}_{2} \mathrm{CO}_{3}$ и $\mathrm{NaHCO}_{3}[16]$.

Недостатками щелочного метода являются большой расход достаточно дорогого $\mathrm{NaOH}$, повышенные температуры щелочной обработки и водного выщелачивания. Кроме того, если монацитовый концентрат содержит примесь марганца, значительно снижается извлечение церия [3, 18]. 
Предложено спекать монацитовый концентрат с хлоридом и карбонатом кальция в восстановительной атмосфере $\left(\mathrm{SO}_{2}\right)$ при температурах 1250-1460 К. Выщелачивание РЗЭ проводят раствором 3 мас. \% $\mathrm{HCl}$. В остатке выщелачивания содержатся хлорапатит и оксид тория. Извлечение РЗЭ в раствор достигает 89 \%, торий остаётся в остатке выщелачивания в виде $\mathrm{ThO}_{2}$, но не сообщается, какая часть его (а она значительна) всё же попадает в раствор выщелачивания. Из-за восстановительной атмосферы присутствие марганца не влияло на извлечение РЗЭ. Способу свойственны недостаточно высокое извлечение РЗЭ, потери фосфора, высокая температура спекания, необходимость создания и поддержания восстановительной атмосферы [19].

В последнее время предложено проводить обесфосфоривание монацита спеканием с содой [20], совмещением щелочной и механохимической обработки [16], разложением в расплаве нитратов щелочных металлов [21]. Разложение в расплаве нитратов проводят при температуре $400-900{ }^{\circ} \mathrm{C}$, удаление фосфора осуществляют путем отделения осветленной фазы расплава и/или выщелачивания фосфата щелочного металла (Na или K) водой.

Таким образом, известные процессы проводятся при высоких температурах, что определяет сложность создания необходимой аппаратуры. В них расходуется значительное количество достаточно дорогих реагентов (кислоты, карбоната, гидроксида или нитрата натрия). Следствием этого является образование большого количества требующих утилизации жидких отходов. При использовании спекательных процессов необходимы использование герметического оборудования и организация очистки отходящих газов от торона. Поэтому актуальна разработка более эффективного метода разложения монацитового концентрата.

Нормативные требования к качеству монацитового концентрата нам неизвестны. В работе использовались его образец, химический состав которого приведён в табл. 11, ортофосфорная кислота. В исследуемом образце содержание РЗЭ, тория, фосфора, циркония соответствовало содержанию этих элементов в складированном в районе Красноуфимска монацитовом концентрате [22], но содержание кальция, титана, железа и кремния намного больше, что указывает на повышенное содержание акцессорных ильменита, циркона и кальциевых алюмосиликатов. Гранулометрический состав монацитового концентрата: $14,8 \%$ класса крупностью $+0,1$ мм, 39,4 \% класса крупностью $-0,1+0,07$ мм, $40,7 \%$ класса крупностью - $0,07+0,05$ мм, 5,1 \% класса крупностью $-0,05$ мм. Для ряда опытов концентрат дополнительно измельчили в планетарной мельнице «Активатор 2 SL» до $100 \%$ крупности не более 0,05 мм.

Процесс переработки монацитового концентрата методом сорбционной конверсии основывается на том, что в фосфорнокислом растворе фосфаты РЗЭ ограниченно растворяются, вероятно, образуя в растворе кислые фосфаты: 


$$
\mathrm{TrPO}_{4(\text { тв. })}+2 \mathrm{H}_{3} \mathrm{PO}_{4} \rightarrow \operatorname{Tr}\left(\mathrm{H}_{2} \mathrm{PO}_{4}\right)_{3(\mathrm{p} \text { - })},
$$

которые частично диссоциируют с образованием содержащих РЗЭ катионов:

$$
\operatorname{Tr}\left(\mathrm{H}_{2} \mathrm{PO}_{4}\right)_{3} \rightarrow \operatorname{Tr}\left(\mathrm{H}_{2} \mathrm{PO}_{4}\right)^{2+}+\mathrm{H}_{2} \mathrm{PO}_{4}^{-} \text {. }
$$

При температурах $20-80{ }^{\circ} \mathrm{C}$ РЗЭ из раствора на основе 38 мас. $\% \mathrm{H}_{3} \mathrm{PO}_{4}$ эффективно сорбируются сульфокатионитом $[23,24]$ :

$$
3\left(-\mathrm{SO}_{3} \mathrm{H}\right)+\operatorname{Tr}\left(\mathrm{H}_{2} \mathrm{PO}_{4}\right)^{2+}+\mathrm{H}_{2} \mathrm{PO}_{4}-\rightarrow\left(-\mathrm{SO}_{3} \mathrm{H}\right)_{3} \mathrm{Tr}+3 \mathrm{H}_{3} \mathrm{PO}_{4} \text {. }
$$

Наличие в фосфорнокислых растворах большого избытка катионов кальция и стронция [25], а также анионов фтора [26] не препятствует в значимой степени сорбции РЗЭ.

Таблица 11

Состав монацитового концентрата

\begin{tabular}{|c|c|c|c|c|c|c|c|}
\hline \multicolumn{10}{|c|}{ Содержание, мас. \% } \\
\hline $\mathrm{Y}_{2} \mathrm{O}_{3}$ & $\mathrm{La}_{2} \mathrm{O}_{3}$ & $\mathrm{Ce}_{2} \mathrm{O}_{3}$ & $\mathrm{Pr}_{2} \mathrm{O}_{3}$ & $\mathrm{Nd}_{2} \mathrm{O}_{3}$ & $\mathrm{Sm}_{2} \mathrm{O}_{3}$ & $\mathrm{Eu}_{2} \mathrm{O}_{3}$ & $\mathrm{Gd}_{2} \mathrm{O}_{3}$ \\
\hline 1,962 & 11,14 & 23,73 & 2,683 & 9,88 & 1,676 & 0,0614 & 1,454 \\
\hline $\mathrm{Tb}_{2} \mathrm{O}_{3}$ & $\mathrm{Dy}_{2} \mathrm{O}_{3}$ & $\mathrm{Ho}_{2} \mathrm{O}_{3}$ & $\mathrm{Er}_{2} \mathrm{O}_{3}$ & $\mathrm{Tm}_{2} \mathrm{O}_{3}$ & $\mathrm{Yb}_{2} \mathrm{O}_{3}$ & $\mathrm{Lu}_{2} \mathrm{O}_{3}$ & $\sum \mathrm{Tr}_{2} \mathrm{O}_{3}$ \\
\hline 0,132 & 0,572 & 0,0671 & 0,138 & 0,0124 & 0,0779 & 0,0096 & 53,60 \\
\hline $\mathrm{Na}_{2} \mathrm{O}$ & $\mathrm{K}_{2} \mathrm{O}$ & $\mathrm{MgO}$ & $\mathrm{CaO}$ & $\mathrm{SrO}$ & $\mathrm{Al}_{2} \mathrm{O}_{3}$ & $\mathrm{TiO}_{2}$ & $\mathrm{Fe}_{2} \mathrm{O}_{3}$ \\
\hline 0,7 & 0,08 & 0,22 & 3,31 & 0,02 & 1,39 & 4,16 & 6,68 \\
\hline $\mathrm{ZrO}_{2}$ & $\mathrm{Nb}_{2} \mathrm{O}_{5}$ & $\mathrm{Ta}_{2} \mathrm{O}_{5}$ & $\mathrm{MnO}$ & $\mathrm{ThO}_{2}$ & $\mathrm{UO}_{2}$ & $\mathrm{P}_{2} \mathrm{O}_{5}$ & $\mathrm{SiO}_{2}$ \\
\hline 3,03 & 0,11 & 0,07 & 0,084 & 3,92 & 0,31 & 22,5 & 10,7 \\
\hline \multicolumn{7}{|c|}{ Содержание в 1000 г, г-экв } \\
\hline $\mathrm{Na}^{+}$ & $\mathrm{K}^{+}$ & $\mathrm{Mg}^{2+}$ & $\mathrm{Ca}^{2+}$ & $\mathrm{Al}^{3+}$ & $\mathrm{Ti}^{4+}$ & $\mathrm{Fe}^{3+}$ \\
\hline 0,61 & 0,04 & 0,11 & \multicolumn{2}{|c|}{1,18} & 0,82 & 2,08 & 2,5 \\
\hline $\mathrm{Zr}^{4+}$ & $\mathrm{Nb}^{+5}$ & $\mathrm{Mn}^{2+}$ & $\mathrm{Th}^{4+}$ & $\mathrm{U}^{4+}$ & $\mathrm{Tr}^{4+}$ & $\sum$ \\
\hline 0,98 & 0,04 & 0,02 & 0,59 & 0,046 & 9,74 & 18,76 \\
\hline
\end{tabular}

Таким образом, в процессе сорбционной конверсии монацита концентрация $\mathrm{H}_{3} \mathrm{PO}_{4}$ будет увеличиваться, а концентрация ионов водорода меняться мало, так как первая константа диссоциации $\mathrm{H}_{3} \mathrm{PO}_{4}$ невелика $\left(7,52 \cdot 10^{-3}\right)$. Следовательно, повышение концентрации $\mathrm{H}_{3} \mathrm{PO}_{4}$ на эффективность сорбции РЗЭ будет влиять незначительно.

Одним из главных факторов, определяющих возможность и глубину протекания процесса сорбционной конверсии, является величина растворимости минерала в кислотном растворе. Важным параметром также является кинетика растворения, зависящая от гидродинамических условий, величины свободной поверхности растворяемого вещества, вязкости раствора. 
Исследования растворимости фосфатов РЗЭ в растворах фосфорной кислоты выполнены группой учёных под руководством И. В. Тананаева [см. обзор в 27]. Равновесная растворимость фосфатов РЗЭ увеличивается при повышении $C_{\mathrm{H}_{3} \mathrm{PO}_{4}}$ (см. рис. 1 и 2) и снижается при повышении температуры.

Так, при повышении температуры с 25 до $80{ }^{\circ} \mathrm{C}$ растворимость $\mathrm{LaPO}_{4}$ в 38 мас. \% фосфорной кислоте уменьшается на порядок [28-30], а $\mathrm{CePO}_{4}-$ в 20 раз [31, 32].

При выборе условий проведения экспериментов учитывали, что повышение температуры снижает равновесную растворимость фосфатов РЗЭ в фосфорнокислом растворе, но может способствовать ускорению растворения монацита. Также разнонаправлено влияет увеличение $C_{\mathrm{H}_{3} \mathrm{PO}_{4}}$, с одной стороны, повышая растворимость фосфатов РЗЭ, а с другой - уменьшая эффективность сорбции РЗЭ [25].

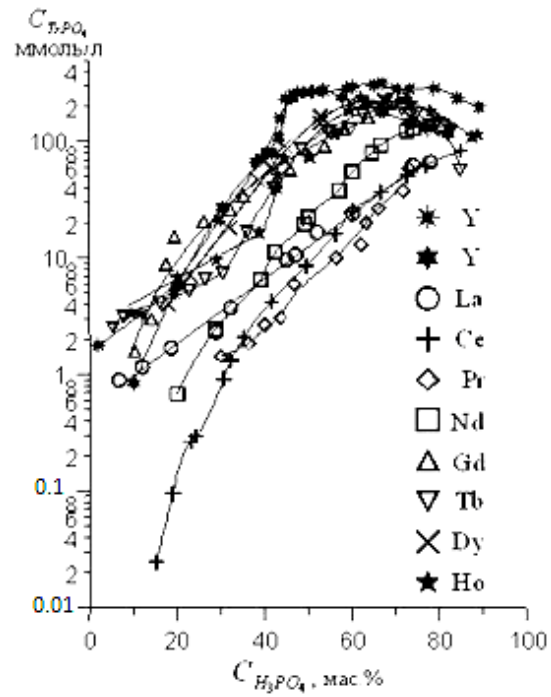

Рис. 1. Зависимость растворимости РЗЭ в фосфорной кислоте от ее концентрации при $25^{\circ} \mathrm{C}$ (для $\mathrm{Ce}-20^{\circ} \mathrm{C}$ ) [см. обзор в 27]

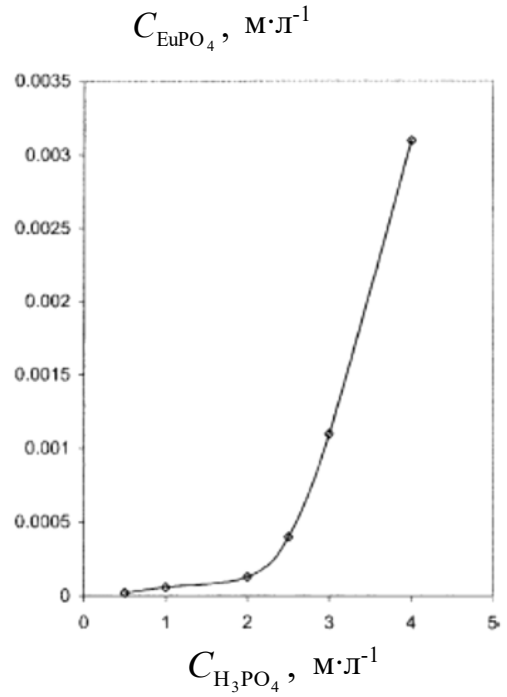

Рис. 2. Зависимость растворимости фосфата европия от концентрации фосфорной кислоты (температура $\left.101-104{ }^{\circ} \mathrm{C}\right)[33]$

В предварительных опытах монацитовый концентрат обрабатывали раствором 40 мас. \% $\mathrm{H}_{3} \mathrm{PO}_{4}$ при величине Ж : Т $=40: 1$. Высокое отношение Ж : Т определялось необходимостью гарантированного погружения сорбента в жидкую фазу. Условия и результаты опытов приведены в табл. 12. 
Таблиия 12

Условия и результаты предварительных опытов по разложению монацитового концентрата крупностью -0,07 мм

\begin{tabular}{|c|c|c|c|c|}
\hline $\begin{array}{c}\text { № } \\
\text { опыта }\end{array}$ & $\begin{array}{c}\text { Расход сорбента, } \\
\%\end{array}$ & $\begin{array}{c}\text { Температура, } \\
{ }^{\circ} \mathrm{C}\end{array}$ & $\begin{array}{c}\text { Время } \\
\text { взаимодействия, ч }\end{array}$ & $\begin{array}{c}\text { Масса остатка, } \\
\%\end{array}$ \\
\hline 1 & 200 & 20 & 4 & 80 \\
\hline 2 & 200 & 40, затем 60 & $8+5$ & 50 \\
\hline 3 & 300 & 60 & 16 & 62 \\
\hline
\end{tabular}

Из данных табл. 12 следует, что сорбционная конверсия монацитового концентрата начинается уже при $20{ }^{\circ} \mathrm{C}$. Повышение температуры процесса с 20 до $80{ }^{\circ} \mathrm{C}$, расхода сорбента и времени обработки не позволяли полностью разложить концентрат. Более того, увеличение расхода сорбента, продолжительности и температуры взаимодействия мало влияло на степень разложения. Рентгенофазовым анализом в остатках определялся только монацит.

В таблице 13 приведены данные о распределении в опыте 2 (табл. 12) катионных компонентов между раствором, остатком и сорбентом, а в табл. 14 - о содержании компонентов в маточном растворе и остатке.

Таблиияа 13

Распределение основных компонентов между продуктами

\begin{tabular}{|l|c|c|c|c|c|c|c|}
\hline \multirow{2}{*}{ Продукт } & \multicolumn{7}{|c|}{ Извлечение в продукты, \% } \\
\cline { 2 - 8 } & $\mathrm{Na}$ & $\mathrm{K}$ & $\mathrm{Mg}$ & $\mathrm{Ca}$ & $\mathrm{Sr}$ & $\mathrm{Al}$ & $\sum \mathrm{Tr}$ \\
\hline Концентрат & 100 & 100 & 100 & 100 & 100 & 100 & 100 \\
\hline Раствор & 8,3 & 12,0 & 4,1 & 4,5 & 34,0 & 7,0 & 0,02 \\
\hline Осадок & 39,3 & 62,5 & 67,9 & 38,5 & 25,0 & 80,5 & 33,71 \\
\hline Сорбент & 52,4 & 25,5 & 28,0 & 57,0 & 41,0 & 12,5 & 66,27 \\
\hline & $\mathrm{Fe}$ & $\mathrm{Si}$ & $\mathrm{Ti}$ & $\mathrm{Zr}$ & $\mathrm{Nb}$ & $\mathrm{Th}$ & $\mathrm{U}$ \\
\hline Концентрат & 100 & 100 & 100 & 100 & 100 & 100 & 100 \\
\hline Раствор & 12,5 & 44,7 & 2,7 & 0,9 & 7,4 & 1,5 & 2,9 \\
\hline Осадок & 61,4 & 55,3 & 90,6 & 61,9 & 70,1 & 53,6 & 64,1 \\
\hline Сорбент & 26,1 & 0 & 6,7 & 37,2 & 22,5 & 44,9 & 33,0 \\
\hline
\end{tabular}

В пределах точности анализа соотношение РЗЭ в растворе, особенно в остатке, соответствовало соотношению в исходном концентрате. Содержание в сорбенте $\sum \operatorname{Tr}_{2} \mathrm{O}_{3}$ составило 17,76 $\Gamma^{\cdot} \pi^{-1}$. Содержание Р3Э в растворе очень мало 
$\left(6,25\right.$ мг $\left.\pi^{-1} \sum \operatorname{Tr}_{2} \mathrm{O}_{3}\right)$, и оно намного меньше равновесной растворимости фосфатов РЗЭ. Это указывало на то, что лимитирующей стадией является не сорбция их из фосфатного раствора, а растворение монацита.

Изменение концентрации фосфорной кислоты в растворе от 30 до $40 \%$, времени обработки до 15 ч и, главное, измельчение в планетарной мельнице мало влияли на эффективность разложения концентрата.

Таблиия 14

Содержание основных примесей в маточном растворе и остатке

\begin{tabular}{|c|c|c|c|c|c|c|c|}
\hline \multirow{2}{*}{ Продукт } & \multicolumn{7}{|c|}{ Содержание в пересчёте на оксиды } \\
\hline & $\mathrm{Na}_{2} \mathrm{O}$ & $\mathrm{K}_{2} \mathrm{O}$ & $\mathrm{MgO}$ & $\mathrm{CaO}$ & $\mathrm{SrO}$ & $\mathrm{Al}_{2} \mathrm{O}_{3}$ & $\sum \mathrm{Tr}_{2} \mathrm{O}_{3}$ \\
\hline Раствор, мг·л ${ }^{-1}$ & 29,1 & 4,78 & 4,50 & 73,8 & 3,38 & 48,8 & 6,25 \\
\hline Остаток, мас. $\%$ & 0,55 & 0,1 & 0,3 & 2,55 & 0,01 & 2,23 & 36,14 \\
\hline & $\mathrm{Fe}_{2} \mathrm{O}_{3}$ & $\mathrm{SiO}_{2}$ & $\mathrm{TiO}_{2}$ & $\mathrm{ZrO}_{2}$ & $\mathrm{Nb}_{2} \mathrm{O}_{5}$ & $\mathrm{ThO}_{2}$ & $\mathrm{UO}_{2}$ \\
\hline Раствор, мг $\pi^{-1}$ & 418 & $\mathrm{H}, \mathrm{a}$, & 55,8 & 13,6 & 3,95 & 30,0 & 4,42 \\
\hline Остаток, мас. & 8,2 & 11,8 & 7,55 & 3,75 & 0,15 & 4,2 & 0,4 \\
\hline
\end{tabular}

Предположили, что недостаточная степень разложения концентрата может определяться рядом причин: 1) нехваткой сорбента; 2) недостаточным временем взаимодействия; 3) затруднением диффузии РЗЭ вглубь зёрен сорбента из-за образования на поверхности этих зёрен «барьера» из сорбированных катионов тория вследствие их низкой скорости диффузии [34]; 4) возможным переходом в процессе обработки церия в четырёхвалентное состояние, который может дополнительно стимулироваться содержащимся в концентрате марганцем [19]; 5) диффузионными затруднениями, вызванными накоплением в растворе устойчивых несорбируемых форм (недиссоциированных молекул, анионных комплексов) фосфатов примесных металлов, препятствующих растворению монацита; 6) диффузионными затруднениями, вызванными образованием на поверхности зёрен монацита высоко химически устойчивых в фосфорнокислом растворе плёнок, препятствующих контакту зёрен монацита с фосфорнокислым раствором.

При повторной обработке остатков в присутствии новых порций фосфорной кислоты и сорбента их масса практически не менялась. Это означало, что первые две причины не являются определяющими.

Отсутствие увеличения концентрации церия относительно других РЗЭ в остатке указывало, что в процессе переход церия в четырёхвалентное состояние не происходил.

При увеличении Ж : Т до 650 в сорбент и раствор перешло соответственно лишь 73,2 и $0,53 \% \sum \operatorname{Tr}_{2} \mathrm{O}_{3}$. Таким образом, недостаточная 
эффективность разложения монацита не была вызвана накоплением в растворе препятствующих растворению монацита устойчивых несорбируемых форм.

Как видно из данных табл. 11 и 14, в процессе обработки содержание $\sum \operatorname{Tr}_{2} \mathrm{O}_{3}$ в остатке снизилось с 53,6 до 36,14 мас. \%. Расчёт на основе полученных экспериментальных данных показал, что количество поглощённых сорбентом катионов должно было привести к потере 72,9 \% массы исходного концентрата. Следовательно, масса остатка должна составлять 27,1 \% массы исходного концентрата, но она оказалась значительно больше (50 \%). Значит, часть растворяющихся в фосфорной кислоте компонентов монацитового концентрата образует осаждающиеся на зёрнах монацита, не содержащие РЗЭ вторичные фазы, увеличивающие массу остатка и, как следствие, определяющие снижение содержания РЗЭ в остатке.

Итак, затруднение разложения монацитового концентрата было связано с образованием в процессе разложения блокирующих растворение покрытий. В растворе 38 мас. \% фосфорной кислоты растворимость фосфатов кальция, алюминия, железа достаточно высока (в экстракционной фосфорной кислоте дигидратного процесса содержание этих металлов составляет несколько граммов в литре каждого, значительно превосходя содержание в маточном растворе разложения монацитового концентрата - см. табл. 14). Небольшое увеличение концентрации алюминия в остатке, по-видимому, определялось присутствием в монацитовом концентрате труднорастворимых в фосфорной кислоте, содержащих алюминий акцессорных минералов, не обнаруживаемых рентгенофазовым анализом из-за их недостаточного содержания.

В качестве компонентов концентрата, вызывающих образование блокирующих растворение монацита покрытий, могли предполагаться образующие малорастворимые фосфаты титан, цирконий, торий и образующийся гидратированный кремнезём (кремнегель), содержание которых в концентрате, как видно из данных табл. 11, достаточно велико. Накопление циркония и тория в остатке не наблюдалось или было невелико. Особенно заметно накопление в остатке титана, который в фосфорнокислом растворе образует малорастворимые фосфатные соединения [35].

Ультразвуковая обработка остатков, которая могла приводить к разрушению образующейся плёнки, оказалась безрезультатной.

Исследовали возможность предотвращения образования плёнок дигидрофосфата титана введением в фосфорнокислый раствор пероксида водорода. При добавлении в фосфорнокислый раствор $\mathrm{H}_{2} \mathrm{O}_{2}$ в количестве, многократно превышающем стехиометрически необходимое для получения пероксидного комплекса титана, доля поглощённого сорбентом титана возросла с 6,7 до 56,8 отн. \%, масса остатка уменьшились с 50 до 37,9 отн. \%, а содержание $\mathrm{TiO}_{2}$ в остатке —с 7,55 до 4,49\%, оказавшись практически равным содержанию $\mathrm{TiO}_{2}$ в исходном концентрате (4,16 мас. \%). Концентрация титана в растворе уменьшилась 
до 39 мг ${ }^{-1}$. Однако поглощение сорбентом РЗЭ увеличилось лишь до 68,8 \%. Таким образом, гипотеза об определяющем влиянии образования на поверхности кристаллов монацита мешающих его растворению плёнок на основе гидратированного фосфата титанила также не нашла подтверждения.

Предположили, что плёнки состоят из гидратированного кремнезёма и могут быть разрушены введением в фосфорнокислый раствор фтор-иона. Введение в раствор фтор-иона в виде $\mathrm{HF}$ или $\mathrm{NaF}$ в количестве $90 \%$ от стехиометрически необходимого для образования имеющимся в концентрате кремнием иона $\mathrm{SiF}_{6}{ }^{2-}$ эффективность процесса не повысило. При введении фториона в количестве $100 \%$ от стехиометрически необходимого для образования имеющимися в концентрате примесями ионов $\mathrm{MeF}_{6}{ }^{3-}(\mathrm{Me}=\mathrm{Al}, \mathrm{Fe})$ и $\mathrm{MeF}_{6}{ }^{2-}(\mathrm{Me}$ $=\mathrm{Si}, \mathrm{Ti}, \mathrm{Zr}, \mathrm{Th}$ ), сорбент поглотил 94,1 \% РЗЭ (табл. 15). При этом в растворе значительно выросла концентрация $\mathrm{Al}$, $\mathrm{Ti}$ и $\mathrm{Fe}$ при извлечении в раствор 71,9-77,6 \% (табл. 16), что указывает на образование ими фторидных или фторфосфатных анионных комплексов.

Таблиия 15

Распределение основных компонентов между продуктами, полученными при сорбционной конверсии с введением НF

\begin{tabular}{|l|c|c|c|c|c|c|c|c|}
\hline \multirow{2}{*}{ Продукт } & \multicolumn{7}{|c|}{ Распределение между продуктами, отн. \% } \\
\cline { 2 - 10 } & $\mathrm{Na}$ & $\mathrm{K}$ & $\mathrm{Mg}$ & $\mathrm{Ca}$ & $\mathrm{Sr}$ & $\mathrm{Al}$ & $\sum \mathrm{Tr}$ & $\mathrm{Ti}$ \\
\hline Концентрат & 100 & 100 & 100 & 100 & 100 & 100 & 100 & 100 \\
\hline Раствор & 21,03 & 31,25 & 39,91 & 37,69 & 16,5 & 74,03 & 0,48 & 71,88 \\
\hline Остаток & 7,74 & 20,75 & 8,96 & 3,61 & 10,0 & 8,64 & 5,41 & 12,24 \\
\hline Сорбент & 71,23 & 48,0 & 51,13 & 58,70 & 73,50 & 17,33 & 94,11 & 15,88 \\
\hline & $\mathrm{Fe}$ & $\mathrm{Zr}$ & $\mathrm{Hf}$ & $\mathrm{Nb}$ & $\mathrm{Ta}$ & $\mathrm{Mn}$ & $\mathrm{Th}$ & $\mathrm{U}$ \\
\hline Концентрат & 100 & 100 & 100 & 100 & 100 & 100 & 100 & 100 \\
\hline Раствор & 77,57 & 1,12 & 19,5 & 62,52 & 48,51 & 12,50 & 13,76 & 13,49 \\
\hline Остаток & 5,32 & 1,45 & 9,0 & 9,53 & 7,14 & 5,24 & 6,60 & 6,09 \\
\hline Сорбент & 17,11 & 93,43 & 71,50 & 27,95 & 44,35 & 82,26 & 79,64 & 80,42 \\
\hline & $\mathrm{Y}$ & $\mathrm{La}$ & $\mathrm{Ce}$ & $\mathrm{Pr}$ & $\mathrm{Nd}$ & $\mathrm{Sm}$ & $\mathrm{Eu}$ & $\mathrm{Gd}$ \\
\hline Концентрат & 100 & 100 & 100 & 100 & 100 & 100 & 100 & 100 \\
\hline Раствор & 0,84 & 0,99 & 0,26 & 0,31 & 0,32 & 0,56 & 0,64 & 0,54 \\
\hline Остаток & 5,45 & 5,85 & 4,87 & 5,65 & 5,62 & 5,94 & 8,06 & 7,58 \\
\hline Сорбент & 93,61 & 93,16 & 94,87 & 94,04 & 94,06 & 93,50 & 91,30 & 91,98 \\
\hline & $\mathrm{Tb}$ & $\mathrm{Dy}$ & $\mathrm{Ho}$ & $\mathrm{Er}$ & $\mathrm{Tm}$ & $\mathrm{Yb}$ & $\mathrm{Lu}$ & $\sum \mathrm{Tr}$ \\
\hline Концентрат & 100 & 100 & 100 & 100 & 100 & 100 & 100 & 100 \\
\hline Раствор & 1,06 & 0,70 & 0,88 & 0,87 & 1,67 & 1,79 & 2,00 & 0,48 \\
\hline Остаток & 9,09 & 6,15 & 7,06 & 5,51 & 5,00 & 5,38 & 4,00 & 5,41 \\
\hline Сорбент & 89,85 & 93,16 & 92,06 & 93,62 & 93,33 & 92,84 & 94,00 & 94,11 \\
\hline
\end{tabular}


Таблица 16

Содержание основных примесей в маточном растворе и остатке

\begin{tabular}{|c|c|c|c|c|c|c|c|}
\hline \multirow{2}{*}{ Продукт } & \multicolumn{7}{|c|}{ Содержание } \\
\hline & $\mathrm{Na}_{2} \mathrm{O}$ & $\mathrm{K}_{2} \mathrm{O}$ & $\mathrm{MgO}$ & $\mathrm{CaO}$ & $\mathrm{MnO}$ & $\mathrm{Al}_{2} \mathrm{O}_{3}$ & $\overline{\mathrm{Fe}_{2} \mathrm{O}_{3}}$ \\
\hline Раствор, мг ${ }^{\cdot}{ }^{-1}$ & 14,7 & 2,5 & 8,8 & 125 & 1,05 & 103 & 518 \\
\hline Осадок, мас. \% & 0,51 & 0,16 & 0,19 & 1,13 & 0,04 & 1,13 & 3,35 \\
\hline & $\sum \mathrm{Tr}_{2} \mathrm{O}_{3}$ & $\mathrm{SiO}_{2}$ & $\mathrm{TiO}_{2}$ & $\mathrm{ZrO}_{2}$ & $\mathrm{ThO}_{2}$ & $\mathrm{UO}_{2}$ & $\mathrm{P}_{2} \mathrm{O}_{5}$ \\
\hline Раствор, мг ${ }^{-1}$ & 25,5 & 3880 & 299 & 15,8 & 53,9 & 4,21 & Н. аэ \\
\hline Осадок, мас. \% & 27,4 & H. a. & 4,81 & 0,02 & 2,44 & 0,18 & 17,6 \\
\hline
\end{tabular}

Таким образом, в фосфорнокислых растворах, как и в сернокислых [36], содержащие фторидные лиганды комплексы Al, Ti и Fe более устойчивы, чем комплекс $\mathrm{SiF}_{6}^{2-}$, а последний более устойчив, чем содержащие фторидные лиганды комплексы РЗЭ. В то же время в фосфорнокислом растворе цирконий не образует устойчивый анионный комплекс с фтором, что определило его высокое поглощение сорбентом из фосфорнокислых растворов, как не содержащих, так и содержащих значительные концентрации фтор-иона.

Как видно из табл. 17, в которой приведены данные о величинах $K_{d}$ при сорбционной конверсии монацитового концентрата в фосфорнокислых растворах различного состава, увеличение температуры с 60 до $80^{\circ} \mathrm{C}$ и введение фтор-иона значительно снижали эффективность сорбции магния, кальция, РЗЭ и тория, а введение в раствор $\mathrm{H}_{2} \mathrm{O}_{2}$ улучшало сорбцию титана и в меньшей степени железа.

Таблица 17

Величины $K_{d}$ при сорбционной конверсии монацитового концентрата в растворах

\begin{tabular}{|c|c|c|c|c|c|c|c|c|c|c|c|c|}
\hline \multirow{2}{*}{$\begin{array}{c}\text { № } \\
\Pi / \Pi\end{array}$} & \multirow[t]{2}{*}{$t,{ }^{\circ} \mathrm{C}$} & \multicolumn{11}{|c|}{$K_{d}$} \\
\hline & & $\mathrm{Na}$ & $\mathrm{K}$ & $\mathrm{Mg}$ & $\mathrm{Ca}$ & $\mathrm{Sr}$ & $\mathrm{Al}$ & $\overline{\mathrm{Ti}}$ & $\mathrm{Fe}$ & Th & $\bar{U}$ & $\sum \operatorname{Tr}$ \\
\hline 1 & 60 & 6,3 & 2,1 & 6,8 & 12,7 & 1,2 & 1,8 & 2,5 & 2,1 & 29,9 & 11,4 & 3313 \\
\hline 2 & 60 & 6,3 & 0,2 & 5,4 & 13,8 & 3,6 & 7,8 & 28,2 & 7,6 & 29,7 & 19,0 & 2292 \\
\hline 3 & 80 & 3,0 & 13,9 & 1,7 & 0,26 & H. a. & 1,8 & 3,8 & 6,0 & 11,1 & 9,8 & 276 \\
\hline
\end{tabular}

Примечание. $1-38$ мас. \% $\mathrm{H}_{3} \mathrm{PO}_{4} ; 2-30$ мас. $\% \mathrm{H}_{3} \mathrm{PO}_{4}+9,7$ мас. $\% \mathrm{H}_{2} \mathrm{O}_{2}$; $3-30$ мас. $\% \mathrm{H}_{3} \mathrm{PO}_{4}+0,3$ мас. $\% \mathrm{HF}$.

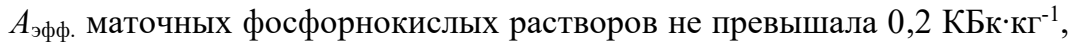
что позволяет работать с ними без ограничений по радиационному фактору. 
Маточные растворы, полученные при использовании в процессе 38 мас. \% $\mathrm{H}_{3} \mathrm{PO}_{4}$, содержали $\left(\mathrm{M \Gamma}^{\cdot} \pi^{-1}\right)$ до $30,7 \mathrm{ThO}_{2}, 3 \mathrm{UO}_{2}, 16 \sum \mathrm{Tr}_{2} \mathrm{O}_{3}, 18 \mathrm{Na}_{2} \mathrm{O}, 3 \mathrm{MgO}$, $7 \mathrm{CaO}, 16 \mathrm{Al}_{2} \mathrm{O}_{3}, 30 \mathrm{TiO}_{2}, 73,5 \mathrm{SiO}_{2}, 220 \mathrm{Fe}_{2} \mathrm{O}_{3}$. Содержание металлов в них мало, что позволяет использовать такие растворы в обороте для обработки следующих порций монацитового концентрата.

При введении в фосфорнокислый раствор фтор-иона содержание многих примесей возрастало (табл. 16). Возможность использования таких растворов в обороте без проведения очистки от фторидных комплексов алюминия, железа, кремния и титана требует проверки.

Поскольку монацитовые концентраты обычно содержат не более 4 мас. \% $\mathrm{SiO}_{2}$, вероятно, что при их переработке количество образующегося кремнегеля будет недостаточно для образования препятствующих растворению монацита плёнок и введение в фосфорнокислый раствор соединений фтора не потребуется.

Содержание в сорбенте достигало $\left(\Gamma^{\cdot} \pi^{-1}\right): 11 \sum \mathrm{Tr}_{2} \mathrm{O}_{3}, 0,69 \mathrm{ThO}_{2}, 0,054 \mathrm{UO}_{2}$, 0,42 $\mathrm{CaO}, 2,48 \mathrm{Fe}_{2} \mathrm{O}_{3}, 0,62 \mathrm{ZrO}_{2}, 0,14 \mathrm{TiO}_{2}, 0,05 \mathrm{Al}_{2} \mathrm{O}_{3}$. При оптимальной организации процесса содержание $\sum \operatorname{Tr}_{2} \mathrm{O}_{3}$ в сорбенте составит $\geq 17,5 \Gamma^{\cdot} \pi^{-1}$. Его $A_{\text {эфф. }}=3,5$ КБк ${ }^{\cdot} \Gamma^{-1}$, т. е. получаемый сорбент относится к III классу материалов с повышенным содержанием природных радионуклидов [8]. Содержание тория в монацитовом концентрате может значительно превышать его содержание в исследовавшейся партии, что будет приводить к ещё большему содержанию радионуклидов в сорбенте.

\section{Выводы}

1. Предложен метод разложения монацитового концентрата, основанный на обработке концентрата фосфорнокислым раствором в присутствии сульфокатионита. При этом РЗЭ, торий, другие металлы преимущественно поглощаются сорбентом, а фосфат-ион переходит в раствор ортофосфорной кислоты, повышая её концентрацию в растворе. Разделение сорбента и раствора не встречает затруднений. Содержание металлов в маточном фосфорнокислом растворе мало, что позволяет его использовать в обороте для обработки следующих порций монацитового концентрата.

2. Разложение монацита начинается уже при $20^{\circ} \mathrm{C}$, но усиливается при температуре $60-80{ }^{\circ} \mathrm{C}$. При содержании в концентрате 10,7 мас. $\% \mathrm{SiO}_{2}$ в сорбент переходило не более 66,3 отн. \% РЗЭ. Затем процесс разложения прекращался из-за образования на поверхности частиц монацита плёнок кремнегеля, препятствующих взаимодействию раствора и монацита.

3. Предотвращение образования плёнок кремнегеля было достигнуто введением в фосфорнокислый раствор фтор-иона в количестве, достаточном для образования не только $\mathrm{SiF}_{6}{ }^{2-}$, но и $\mathrm{AlF}_{6}{ }^{3-}, \mathrm{FeF}_{6}{ }^{3-}$ и $\mathrm{TiF}_{6}{ }^{2-}$. При этом извлечение 
РЗЭ в сорбент достигало 94,1 \%, но содержание примесей алюминия, железа, титана и в меньшей степени тория и урана в маточном растворе возросло.

4. Обычно монацитовые концентраты содержат не более 4 мас. \% $\mathrm{SiO}_{2}$. Вероятно, что при их переработке количество кремнезёма будет недостаточным для образования плёнок на основе кремнегеля, следовательно, введение в фосфорнокислый раствор соединений фтора для обеспечения эффективного разложения монацитового концентрата не потребуется.

\section{2. Разложение фосфатного концентрата, осаждаемого из растворов азотнокислотного разложения апатитового концентрата}

При нейтрализации азотно-фосфорнокислого раствора промежуточного продукта азотнокислотной переработки хибинского апатитового концентрата - РЗЭ могут быть выделены в виде фосфатного концентрата [1]. В редкоземельный концентрат попадает значительная часть содержащихся в апатите радионуклидов, главным образом тория. Недавно разработан более эффективный метод получения такого концентрата, позволяющий значительно увеличить в нем выход и содержание РЗЭ [37]. В этом методе формирование концентрата осуществляется при повышенной температуре $85-95^{\circ} \mathrm{C}$.

Переработка концентрата должна включать отделение РЗЭ от фосфора и радионуклидов. Для отделения фосфора из фосфатов РЗЭ предлагался ряд подходов, среди которых конверсия фосфатов РЗЭ в оксалаты [38], углетермическая отгонка фосфора [39].

Наиболее развит метод, основанный на растворении концентрата в 56-58 мас. \% $\mathrm{HNO}_{3}$, содержащей добавку $\mathrm{H}_{2} \mathrm{O}_{2}$, с последующей экстракцией РЗЭ из получающегося азотно-фосфорнокислого раствора [40, 41].

Нами исследована возможность переработки таких концентратов методом сорбционной конверсии. При этом учитывали, что в концентрат попадают гидратированные фосфаты РЗЭ, которые должны растворяться в минеральных кислотах значительно легче монацита.

\subsection{1. Разложение с использованием азотнокислых растворов}

Эффективность растворения в минеральных кислотах гидратированных фосфатов РЗЭ, составляющих значительную часть концентрата, зависит от степени их гидратации, на которую влияет температура синтеза. Получаемые при повышенных температурах гидратированные фосфаты РЗЭ могут иметь пониженную степень гидратации (меньше одной 
молекулы воды на молекулу фосфата). Это затрудняет их растворимость в растворах серной [42] и азотной [43] кислот.

Поэтому не исключалось, что использование повышенной температуры при получении концентрата по способу [37] может вызывать снижение степени гидратации фосфатов РЗЭ и, как следствие, сильно затруднить сорбционную конверсию.

Состав использованных в работе фосфатных концентратов приведён в табл. 18. Расчёт мольного соотношения суммы катионов и фосфора подтверждает, что часть катионов присутствует в концентратах в виде кислых фосфатов. Наличие в концентратах небольшого количества фтора определяется, по-видимому, попаданием фторосиликатов щелочных металлов $\mathrm{Na}_{2} \mathrm{SiF}_{6}$ и/или $\mathrm{K}_{2} \mathrm{SiF}_{6}$ либо фтор-фосфатных комплексов алюминия и других катионов с фторакцепторными свойствами $\left(\mathrm{Ti}^{4+}, \mathrm{Fe}^{3+}\right)$. Суммарное содержание химически связанной воды составляло 26,2-37,4 мас. \%, уменьшаясь с увеличением концентрации РЗЭ в концентрате. В табл. 19 приведено содержание в концентрате оксидов индивидуальных РЗЭ. Сравнение соотношения оксидов РЗЭ в фосфатных концентратах и исходном апатитовом концентрате показывает, что при осаждении фосфатного концентрата извлечение РЗЭ иттриевой группы не превышает $40 \%$, средней группы - $60 \%$.

Таблицุа 18

Состав полученных концентратов

\begin{tabular}{|c|c|c|c|c|c|c|}
\hline \multirow{2}{*}{ Концентрат } & \multicolumn{7}{|c|}{ Содержание, мас. \% } \\
\cline { 2 - 7 } & $\mathrm{Na}_{2} \mathrm{O}$ & $\mathrm{K}_{2} \mathrm{O}$ & $\mathrm{MgO}$ & $\mathrm{CaO}$ & $\mathrm{Al}_{2} \mathrm{O}_{3}$ & $\mathrm{TiO}_{2}$ \\
\hline 1 & 0,85 & 0,14 & 0,30 & 6,50 & 0,94 & 0,59 \\
\hline 2 & 0,59 & 0,20 & 0,08 & 3,05 & 0,59 & 1,28 \\
\hline $3^{*}$ & 0,21 & 0,23 & 0,03 & 12,2 & 3,21 & 0,53 \\
\hline \multirow{2}{*}{ Концентрат } & \multicolumn{7}{|c|}{ Содержание, мас. \% } \\
\cline { 2 - 7 } & $\mathrm{Fe}_{2} \mathrm{O}_{3}$ & $\mathrm{ThO}_{2}$ & $\mathrm{UO}_{2}$ & $\mathrm{P}_{2} \mathrm{O}_{5}$ & $\mathrm{~F}$ & $\sum \mathrm{Tr}_{2} \mathrm{O}_{3}$ \\
\hline 1 & 0,19 & 0,077 & 0,002 & 28,7 & 0,81 & 23,5 \\
\hline 2 & 1,16 & 0,121 & 0,0013 & 28,8 & 0,28 & 33,7 \\
\hline $3^{*}$ & 2,24 & 0,078 & 0,0003 & 47,4 & 1,77 & 23,53 \\
\hline
\end{tabular}

" Концентрат термообработан в водной среде при температуре $95^{\circ} \mathrm{C}$.

Навеску фосфатных концентратов РЗЭ помещали в азотнокислый раствор (Ж : Т = 10) заданной концентрации. В пульпу добавляли сорбент с расходом $10 \mathrm{~cm}^{3}$ сорбента на 1 г концентрата. Полученную смесь перемешивали в течение 2 ч при заданной температуре. Выбранный расход 
катионита превышал необходимый для сорбции всех катионов концентрата для сорбентов 2 и 3 в 1,5, для сорбента 1 - в 2,25 раза. Если конверсия проходила не до конца, отделяли сорбент от маточной азотнокислой пульпы, содержавшей взвесь нерастворившихся компонентов фосфатного концентрата, повторяли обработку маточной азотнокислотной пульпы, добавляя новую порцию сорбента.

Таблийа 19

Содержание индивидуальных РЗЭ в концентратах

\begin{tabular}{|c|c|r|r|r|r|r|r|c|}
\hline \multirow{2}{*}{ Концентрат } & \multicolumn{7}{|c|}{ Содержание, мас. \% } \\
\cline { 2 - 9 } & $\mathrm{Y}_{2} \mathrm{O}_{3}$ & $\mathrm{La}_{2} \mathrm{O}_{3}$ & $\mathrm{Ce}_{2} \mathrm{O}_{3}$ & $\mathrm{Pr}_{2} \mathrm{O}_{3}$ & $\mathrm{Nd}_{2} \mathrm{O}_{3}$ & $\mathrm{Sm}_{2} \mathrm{O}_{3}$ & $\mathrm{Eu}_{2} \mathrm{O}_{3}$ & $\mathrm{Gd}_{2} \mathrm{O}_{3}$ \\
\hline 1 & 0,484 & 5,818 & 11,33 & 1,034 & 3,476 & 0,469 & 0,12 & 0,486 \\
\hline 2 & 0,870 & 8,04 & 17,08 & 1,483 & 4,532 & 0,601 & 0,163 & 0,607 \\
\hline 3 & 0,59 & 6,04 & 11,27 & 0,99 & 3,30 & 0,48 & 0,123 & 0,441 \\
\hline \multirow{8}{*}{ Концентрат } & \multicolumn{7}{|c|}{ Содержание, мас. \% } \\
\cline { 2 - 9 } & $\mathrm{Tb}_{2} \mathrm{O}_{3}$ & $\mathrm{Dy}_{2} \mathrm{O}_{3}$ & $\mathrm{Ho}_{2} \mathrm{O}_{3}$ & $\mathrm{Er}_{2} \mathrm{O}_{3}$ & $\mathrm{Tm}_{2} \mathrm{O}_{3}$ & $\mathrm{Yb}_{2} \mathrm{O}_{3}$ & $\mathrm{Lu}_{2} \mathrm{O}_{3}$ & $\sum \mathrm{Tr}_{2} \mathrm{O}_{3}$ \\
\hline 1 & 0,043 & 0,17 & 0,0195 & 0,0431 & 0,003 & 0,012 & 0,0011 & 23,5 \\
\hline 2 & 0,057 & 0,205 & 0,024 & 0,051 & 0,004 & 0,023 & 0,002 & 33,7 \\
\hline 3 & 0,049 & 0,166 & 0,023 & 0,046 & 0,005 & 0,014 & 0,002 & 23,53 \\
\hline
\end{tabular}

Сорбционную конверсию концентрата 1 проводили при температуре 20 ${ }^{\circ} \mathrm{C}$, а концентратов 2 и 3 - при температуре $80{ }^{\circ} \mathrm{C}$. Данные по эффективности сорбционной конверсии приведены в табл. 20.

Таблица 20

Эффективность сорбционной конверсии фосфатного концентрата при температуре $20{ }^{\circ} \mathrm{C}$

\begin{tabular}{|c|c|c|c|c|c|c|c|c|c|c|}
\hline \multirow{2}{*}{$\begin{array}{c}\text { Кон- } \\
\text { центрат }\end{array}$} & \multirow{2}{*}{$\begin{array}{l}C_{\mathrm{HNO}_{3}}, \\
\text { мac. \% }\end{array}$} & \multirow{2}{*}{$\begin{array}{l}\text { Ста- } \\
\text { дия }\end{array}$} & \multicolumn{8}{|c|}{ Извлечение в сорбент, отн. \% } \\
\hline & & & $\mathrm{Y}_{2} \mathrm{O}_{3}$ & $\mathrm{La}_{2} \mathrm{O}_{3}$ & $\mathrm{Ce}_{2} \mathrm{O}_{3}$ & $\mathrm{Pr}_{2} \mathrm{O}_{3}$ & $\mathrm{Nd}_{2} \mathrm{O}_{3}$ & $\mathrm{Sm}_{2} \mathrm{O}_{3}$ & $\mathrm{Eu}_{2} \mathrm{O}_{3}$ & $\mathrm{Gd}_{2} \mathrm{O}_{3}$ \\
\hline \multirow[t]{2}{*}{1} & \multirow[t]{2}{*}{3} & 1 & 88,3 & 82,6 & 66,3 & 81,4 & 83,0 & 82,0 & 82,3 & 77,3 \\
\hline & & $1+2$ & 99,1 & 98,7 & 97,7 & 98,7 & 98,9 & 98,7 & 98,7 & 98,3 \\
\hline \multirow[t]{2}{*}{1} & \multirow[t]{2}{*}{6} & 1 & 88,1 & 83,6 & 62,2 & 81,7 & 81,2 & 81,0 & 82,3 & 76,8 \\
\hline & & $1+2$ & 98,2 & 98,6 & 96,3 & 98,4 & 98,6 & 98,3 & 98,4 & 97,8 \\
\hline 2 & 2 & - & 98,3 & 97,4 & 94,6 & 96,6 & 96,6 & 96,4 & 96,6 & 96,3 \\
\hline 3 & 2 & - & 98,3 & 98,2 & 96,6 & 97,6 & 97,6 & 97,7 & 97,8 & 97,3 \\
\hline
\end{tabular}




\begin{tabular}{|c|c|c|c|c|c|c|c|c|c|c|}
\hline \multirow{2}{*}{$\begin{array}{c}\text { Кон- } \\
\text { центрат }\end{array}$} & \multirow{2}{*}{$\begin{array}{l}C_{\mathrm{HNO}_{3}}, \\
\text { мac. \% }\end{array}$} & \multirow{2}{*}{$\begin{array}{l}\text { Ста- } \\
\text { дия }\end{array}$} & \multicolumn{8}{|c|}{ Извлечение в сорбент, отн. \% } \\
\hline & & & $\mathrm{Tb}_{2} \mathrm{O}_{3}$ & $\mathrm{Dy}_{2} \mathrm{O}_{3}$ & $\mathrm{Ho}_{2} \mathrm{O}_{3}$ & $\mathrm{Er}_{2} \mathrm{O}_{3}$ & $\mathrm{Tm}_{2} \mathrm{O}_{3}$ & $\mathrm{Yb}_{2} \mathrm{O}_{3}$ & $\mathrm{Lu}_{2} \mathrm{O}_{3}$ & $\sum \operatorname{Tr}_{2} \mathrm{O}_{3}$ \\
\hline \multirow[t]{2}{*}{1} & \multirow[t]{2}{*}{3} & 1 & 82,1 & 83,2 & 83,6 & 84,0 & 83,3 & 85,0 & 81,8 & 74,8 \\
\hline & & $1+2$ & 98,7 & 98,7 & 98,7 & 98,8 & 99,0 & 98,8 & 99,1 & 98,3 \\
\hline \multirow[t]{2}{*}{1} & \multirow[t]{2}{*}{6} & 1 & 82,1 & 81,9 & 84,1 & 83,1 & 83,3 & 83,3 & 81,8 & 72,7 \\
\hline & & $1+2$ & 98,4 & 98,4 & 98,4 & 98,5 & 98,3 & 98,9 & 98,2 & 97,4 \\
\hline 2 & 2 & - & 96,3 & 96,6 & 96,5 & 97,0 & 95,8 & 96,4 & 95,8 & 95,8 \\
\hline 3 & 2 & - & 97,9 & 97,6 & 98,1 & 97,8 & 98,4 & 97,3 & 98,2 & 97,3 \\
\hline \multirow{2}{*}{$\begin{array}{c}\text { Кон- } \\
\text { центрат }\end{array}$} & \multirow{2}{*}{$C_{\mathrm{HNO}_{3}}$} & \multirow{2}{*}{$\begin{array}{l}\text { Ста- } \\
\text { дия }\end{array}$} & \multicolumn{8}{|c|}{ Извлечение в сорбент, отн. \% } \\
\hline & & & $\mathrm{Na}_{2} \mathrm{O}$ & $\mathrm{MgO}$ & $\mathrm{CaO}$ & $\mathrm{Al}_{2} \mathrm{O}_{3}$ & $\mathrm{TiO}_{2}$ & $\mathrm{Fe}_{2} \mathrm{O}_{3}$ & $\mathrm{ThO}_{2}$ & $\mathrm{UO}_{2}$ \\
\hline \multirow[t]{2}{*}{1} & \multirow[t]{2}{*}{3} & 1 & 99,9 & 99,6 & 98,9 & 99,8 & 86,7 & 86,8 & 86,8 & 93,8 \\
\hline & & $1+2$ & 100 & 100 & 99,4 & 100 & 91,7 & 99,2 & 99,8 & 99,0 \\
\hline \multirow[t]{2}{*}{1} & \multirow{2}{*}{6} & 1 & 90,8 & 93,5 & 80,0 & 65,6 & 28,9 & 98,5 & 36,8 & 95,0 \\
\hline & & $1+2$ & 96,2 & 97,6 & 98,1 & 93,9 & 67,6 & 99,8 & 87,0 & 98,5 \\
\hline 2 & 2 & - & 78,1 & 97,3 & 95,1 & 91,7 & 75,4 & 87,9 & 85,2 & 98,1 \\
\hline 3 & 2 & - & 74,2 & 90,9 & 97,4 & 71,7 & 9,7 & 84,2 & 75,4 & 87,7 \\
\hline
\end{tabular}

Представленные в табл. 20 данные показывают, что сорбционная конверсия фосфатного концентрата РЗЭ в азотнокислой среде эффективна, при этом имеет место высокая степень сорбции практически всех катионов. При комнатной температуре для достижения высокой степени конверсии требовалось её проведение в две стадии, в то время как при температуре $80{ }^{\circ} \mathrm{C}$ при одинаковом соотношении реагентов достаточная для практики полнота конверсии достигалась за одну стадию. Повышение $C_{\mathrm{HNO}_{3}}$ с 3 до 6 мас. \% затрудняло сорбционную конверсию. Полнота перехода в сорбент всех РЗЭ, как правило, была одинакова. При использовании 6 мас. \% раствора и ограниченном расходе сорбента (первая стадия) затруднялся переход в сорбент тория, что указывает на принципиальную возможность частичного отделения тория в процессе сорбционной конверсии фосфатного концентрата, однако при этом снижалась и степень сорбции РЗЭ. В целом отделение тория от РЗЭ непосредственно в процессе сорбционной конверсии в азотнокислых средах малоперспективно.

Труднее всего поглощался сорбентом титан, что, вероятно, связано с его присутствием в концентрате в виде труднорастворимого гидратированного фосфата титанила $\mathrm{TiOHPO}_{4} \cdot \mathrm{xH}_{2} \mathrm{O}$. 
Рассчитанная по экспериментальным данным степень насыщения сорбента (допускалось, что сорбируются катионы, а не содержащие анионные лиганды положительно заряженные комплексы) составила 74,1, 36,7 и 34 отн. $\%$ при $C_{\mathrm{HNO}_{3}}$, равной соответственно 2, 3 и 6 мас. \%. Таким образом, снижение концентрации азотной кислоты с 6 до 3 мас. \% мало влияло на практическую сорбционную ёмкость сульфокатионита. Значительное увеличение практической сорбционной ёмкости сульфокатионита при $C_{\mathrm{HNO}_{3}}=2$ мас. \% может быть объяснено снижением концентрации катионов водорода.

Таким образом, 1 дм ${ }^{3}$ сорбента КУ-2-8чС в процессе сорбционной конверсии фосфатного концентрата изученного состава может содержать более 32 г $\sum \operatorname{Tr}_{2} \mathrm{O}_{3}$. Повышение содержания Р3Э в фосфатном концентрате будет способствовать повышению содержания РЗЭ в сорбенте. Расход 56 мас. \% $\mathrm{HNO}_{3}$ составил около 1 кг на 1 кг оксидов РЗЭ в фосфатном концентрате, т. е. был в четыре раза меньше, чем в известном методе [41].

Результаты сорбционной конверсии фосфатного концентрата, полученного при $95{ }^{\circ} \mathrm{C}$, и фосфатного концентрата, полученного при использовании обычного режима осаждения при $80^{\circ} \mathrm{C}$, мало отличались [1].

В маточном азотнокислом растворе концентрация $\mathrm{P}_{2} \mathrm{O}_{5}$ достигала $25 \Gamma^{\cdot} \pi^{-1}$, фтора $-1,6 \Gamma^{\cdot} \pi^{-1}$. Их состав и относительно небольшой объём определяют возможность их использования в основном производстве.

\section{Выводы}

1. При сорбционной конверсии фосфатного концентрата РЗЭ в среде низкоконцентрированной азотной кислоты фосфор и фтор эффективно отделяются от РЗЭ. Снижение концентрации азотной кислоты в растворе, используемом в качестве среды для сорбционной конверсии, с 6 до 2 мас. \% при одновременном повышении температуры с 20 до $80{ }^{\circ} \mathrm{C}$ повышает эффективность сорбционной конверсии.

2. При сорбционной конверсии РЗЭ переходят в сульфокатионит на 95,898,3 \% практически в равной степени, при этом лишь для церия степень конверсии несколько понижена.

3. Основная часть катионных примесей, в том числе тория и урана, переходит в сульфокатионит, но в несколько меньшей по сравнению с РЗЭ степени. Значимого для практики отличия в степени поглощения сорбентом РЗЭ и радионуклидов не найдено.

4. При переработке фосфатного концентрата РЗЭ, содержавшего 33,7 \% $\sum \operatorname{Tr}_{2} \mathrm{O}_{3}$, концентрация $\sum \operatorname{Tr}_{2} \mathrm{O}_{3}$ в 1 л сульфокатионита превышала 32 г, она может быть увеличена при оптимизации параметров процесса сорбционной конверсии. 


\subsection{2. Разложение с использованием фторсодержащих азотнокислых растворов}

Как видно из данных табл. 20, при азотнокислотном разложении концентрата РЗЭ, торий, алюминий, титан, железо образуют катионные комплексы, что определяет их эффективное поглощение сорбентом. При последующей переработке сорбента в качестве одного из продуктов получается обогащённый торием примесный кек. Он, имея повышенную радиоактивность, требует специальных методов обращения, что осложняет реализацию такой технологии. Кроме того, растворами нитрата аммония торий десорбируется неудовлетворительно и при их использовании будет накапливаться в сорбенте. Торий может десорбироваться растворами сульфата аммония, но их утилизация на заводах, перерабатывающих апатитовый концентрат азотнокислотным методом, затруднительна. Поэтому представлял интерес поиск методов, позволяющих разделять РЗЭ и торий непосредственно в процессе сорбционной конверсии фосфатного концентрата РЗЭ с предотвращением получения отходов с повышенной радиоактивностью.

Исследовали возможность отделения тория от РЗЭ непосредственно в процессе обесфосфоривания концентрата методом сорбционной конверсии. При этом предположили, что введение в азотнокислый раствор фтор-иона позволит решить поставленную задачу, так как: 1) торий будет образовывать с фтор-ионом малорастворимый в низкоконцентрированных азотнокислых растворах фторид тория, что затруднит поглощение тория сорбентом; 2) хотя РЗЭ также образуют малорастворимые фториды (в 2 мас. $\% \mathrm{HNO}_{3}$ растворимость $\mathrm{YF}_{3} 0,1 \Gamma^{\cdot} \pi^{-1}$ [12], растворимость $\mathrm{LaF}_{3}$ почти в три раза ниже [13]), их растворимость значительно больше растворимости фторида тория, что открывает возможность поиска условий проведения процесса, обеспечивающих эффективное разделение РЗЭ и тория.

Обработку проводили в течение 2 ч при температуре $80^{\circ} \mathrm{C}$ в растворах, содержавших 1-2,5 мас. \% $\mathrm{HNO}_{3}$, в которые предварительно вводили содержащие фтор-ион соединения: $\mathrm{NaF}$ (ГОСТ 4463-76), $\mathrm{NH}_{4} \mathrm{~F}$ (ГОСТ 4518-75), $\mathrm{NH}_{4} \mathrm{HF}_{2}$ (ГОСТ 9546-75) или НF. Отношение массы концентрата к объёмам кислотного раствора и сорбента равнялось $1: 10: 6$. В зависимости от концентрации $\mathrm{HNO}_{3}$ её расход оставлял 21,6-54 \% от расхода, теоретически необходимого для образования нитратов содержащимися в концентрате катионами металлов.

Сорбционная ёмкость вводившегося сорбента могла обеспечить поглощение лишь 85 \% содержавшихся в концентрате катионов РЗЭ, щелочных, щелочноземельных металлов, алюминия, титана и железа (III). Полагали, что недостаток сорбента не снизит поглощение более легко сорбируемых 
сульфокатионитом РЗЭ, но приведёт к уменьшению поглощения некоторых примесей.

Состав исходного концентрата приведён в табл. 21. Он содержал также (мас. \%): $3,76 \mathrm{NH}_{4}^{+}$и 1,03 $\mathrm{SiO}_{2}$. Основными катионными примесями были аммоний, кальций, алюминий, железо (III) и титан.

Таблицуа 21

Состав исходного концентрата

\begin{tabular}{|c|c|c|c|c|c|c|c|c|c|c|c|}
\hline \multicolumn{10}{|c|}{ Содержание, мас. \% } \\
\hline$\sum \mathrm{Tr}_{2} \mathrm{O}_{3}$ & $\mathrm{Me}_{2} \mathrm{O}$ & $\mathrm{MgO}$ & $\mathrm{CaO}$ & $\mathrm{SrO}$ & $\mathrm{Al}_{2} \mathrm{O}_{3}$ & $\mathrm{TiO}_{2}$ & $\mathrm{Fe}_{2} \mathrm{O}_{3}$ & $\mathrm{ThO}_{2}$ & $\mathrm{UO}_{2}$ & $\mathrm{PO}_{4}{ }^{3-}$ & $\mathrm{F}$ \\
\hline 12,21 & 0,15 & 0,041 & 5,704 & 0,591 & 2,093 & 0,854 & 3,517 & 0,0294 & $1 \cdot 10^{-4}$ & 31,84 & 1,55 \\
\hline \multicolumn{10}{|c|}{ Г-экв в 1000 г } \\
\hline $\mathrm{Tr}^{3+}$ & $\mathrm{Me}^{+}$ & $\mathrm{Mg}^{2+}$ & $\mathrm{Ca}^{2}+$ & $\mathrm{Sr}^{2+}$ & $\mathrm{Al}^{3+}$ & $\mathrm{Ti}^{4+}$ & $\mathrm{Fe}^{3+}$ & $\mathrm{Th}^{4+}$ & $\mathrm{U}^{4+}$ & $\mathrm{PO}_{4}{ }^{3-}$ & $\mathrm{F}^{-}$ \\
\hline 2,22 & 0,044 & 0,020 & 2,04 & 0,114 & 1,23 & 0,43 & 1,32 & $1,1 \cdot 10^{-3}$ & $3,7 \cdot 10^{-6}$ & 10,05 & 0,82 \\
\hline
\end{tabular}

Из соотношения эквивалентов катионов и аниона $\mathrm{PO}_{4}^{3-}$ следует, что в концентрате катионы присутствуют преимущественно в виде средних фосфатов.

По сравнению с исследовавшимися ранее концентратами [44] концентрат отличался более высоким содержанием кальция, алюминия, железа и более низким содержанием РЗЭ и природных радионуклидов - тория и урана.

По содержанию тория относительно содержания $\sum \operatorname{Tr}_{2} \mathrm{O}_{3}$ оценивали

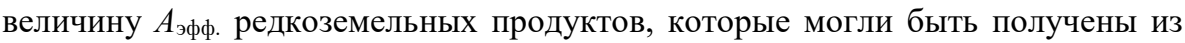
концентрата. При этом принимали содержание в них $\sum \operatorname{Tr}_{2} \mathrm{O}_{3}$ равным $100 \%$. Содержанием урана пренебрегали, так как его вклад из-за низкой концентрации в суммарную активность менее 1 отн. \%. Для исходного концентрата $A_{\text {эфф. }}=$ 7,56 КБк $\kappa^{-1}$.

Условия и результаты экспериментов представлены в табл. 22-24. Расход фтор-иона приведён в граммах на 1 кг концентрата. Учитывали, что:

1) в процессе сорбционной конверсии в растворе по реакции (9) будет образовываться фосфорная кислота: при выбранном соотношении реагентов и полном разложении концентрата её концентрация может достигать $\approx 3,3$ мас. \%;

2) введение содержащих фтор-ион соединений приводит к увеличению концентрации в растворе катионов аммония или натрия, которые при сорбции являются конкурентами переходящих в раствор из концентрата катионов металлов.

Исследование в качестве добавки $\mathrm{NaF}$ (опыты 1-7) было обусловлено его более низкой ценой и возможностью производства на предприятиях, перерабатывающих апатитовый концентрат азотнокислотным методом. Однако при этом в растворе значительно снижалась кислотность раствора, так как $\mathrm{NaF}$ - соль сильного основания и слабой кислоты. 
Таблииа 22

Влияние условий проведения сорбционной конверсии на извлечение РЗЭ в сорбент, долю замещённых катионообменных центров сорбента $\alpha$ (отн. \%), содержание $\sum \operatorname{Tr}_{2} \mathrm{O}_{3}$ в 1 л сорбента $m$ (г) и $A_{\text {эфф. }}$ (КБк к к $\left.{ }^{-1}\right)$

\begin{tabular}{|c|c|c|c|c|c|c|c|c|c|c|}
\hline \multirow[b]{2}{*}{ Опыт } & \multicolumn{5}{|c|}{ Раствор } & \multicolumn{5}{|c|}{ Сорбент } \\
\hline & $\begin{array}{c}\text { введено } \\
\mathrm{F}^{-}, \text {г }\end{array}$ & соединение & $\begin{array}{c}C_{\mathrm{HNO}_{3}} \\
\text { мac. } \%\end{array}$ & $\begin{array}{c}C_{\mathrm{NH}_{4}{ }^{+}}, \\
\text {моль } \cdot \pi^{-1}\end{array}$ & $\begin{array}{c}C_{\mathrm{Na}^{+}}, \\
\text {моль } \cdot \pi^{-1}\end{array}$ & $\begin{array}{l}t, \\
{ }^{\circ} \mathrm{C}\end{array}$ & $\varepsilon_{\mathrm{Tr}}$ & $\alpha$ & $m$ & $A_{\text {эфф. }}$ \\
\hline 1 & 0 & - & 2 & 0,21 & - & 80 & 92,9 & 54,2 & 18,9 & 4,70 \\
\hline 2 & 25 & $\mathrm{NaF}$ & 2 & 0,21 & 0,13 & 80 & 97,7 & 64,5 & 19,9 & 3,59 \\
\hline 3 & 50 & $\mathrm{NaF}$ & 2 & 0,21 & 0,26 & 80 & 95,5 & 72,1 & 19,4 & 3,32 \\
\hline 4 & 75 & $\mathrm{NaF}$ & 2 & 0,21 & 0,39 & 80 & 93,1 & 75,1 & 18,4 & 1,61 \\
\hline 5 & 100 & $\mathrm{NaF}$ & 2 & 0,21 & 0,53 & 80 & 82,9 & 75,1 & 16,9 & 1,21 \\
\hline 6 & 125 & $\mathrm{NaF}$ & 2 & 0,21 & 0,66 & 80 & 67,6 & 85,9 & 13,8 & 0,31 \\
\hline 7 & 125 & $\mathrm{NaF}$ & 2,5 & 0,21 & 0,66 & 80 & 75,1 & 89,0 & 15,3 & 2,38 \\
\hline 8 & 50 & $\mathrm{NH}_{4} \mathrm{~F}$ & 1 & 0,47 & - & 80 & 70,2 & 49,3 & 14,4 & 2,3 \\
\hline 9 & 75 & $\mathrm{NH}_{4} \mathrm{~F}$ & 1 & 0,60 & - & 80 & 70,8 & 51,5 & 14,3 & 2,4 \\
\hline 10 & 75 & $\mathrm{NH}_{4} \mathrm{~F}$ & 2 & 0,60 & - & 20 & 64,3 & 37,7 & 13,1 & 3,24 \\
\hline 11 & 75 & $\mathrm{NH}_{4} \mathrm{~F}$ & 2,5 & 0,60 & - & 20 & 66,2 & 41,4 & 13,5 & 3,57 \\
\hline 12 & 75 & $\mathrm{NH}_{4} \mathrm{~F}$ & 2 & 0,60 & - & 80 & 82,8 & 47,1 & 16,8 & 2,46 \\
\hline 13 & 100 & $\mathrm{NH}_{4} \mathrm{~F}$ & 2,5 & 0,74 & - & 80 & 81,6 & 47,8 & 16,6 & 2,32 \\
\hline 14 & 125 & $\mathrm{NH}_{4} \mathrm{~F}$ & 2,5 & 0,87 & - & 80 & 68,0 & 48,9 & 13,8 & 1,27 \\
\hline 15 & 100 & $\mathrm{NH}_{4} \mathrm{HF}_{2}$ & 1 & 0,47 & - & 80 & 92,7 & 54,0 & 18,9 & 0,39 \\
\hline 16 & 125 & $\mathrm{NH}_{4} \mathrm{HF}_{2}$ & 1 & 0,54 & - & 80 & 88,1 & 52,0 & 17,9 & 0,11 \\
\hline 17 & 100 & $\mathrm{HF}$ & 1 & 0,21 & - & 80 & 95,7 & 53,3 & 19,5 & 0,21 \\
\hline 18 & 125 & $\mathrm{HF}$ & 1 & 0,21 & - & 80 & 91,8 & 52,5 & 18,7 & 0,12 \\
\hline
\end{tabular}

Таблица 23

Извлечение основных примесных катионов концентрата в сорбент

\begin{tabular}{|c|r|r|r|c|c|c|c|c|c|}
\hline \multirow{2}{*}{ Опыт } & \multicolumn{8}{|c|}{ Извлечение в сорбент, отн. \% } \\
\cline { 2 - 12 } & $\mathrm{Na}$ & $\mathrm{K}$ & $\mathrm{Mg}$ & $\mathrm{Ca}$ & $\mathrm{Al}$ & $\mathrm{Ti}$ & $\mathrm{Fe}$ & $\mathrm{Th}$ & $\mathrm{U}$ \\
\hline 1 & \multicolumn{1}{|c}{2} & 3 & 4 & 5 & 6 & 7 & 8 & 9 & 10 \\
\hline 1 & 44,5 & 40,4 & 42,8 & 90,0 & 58,1 & 45,1 & 74,0 & 65,2 & 72,3 \\
\hline 2 & 67,9 & 22,6 & 75,6 & 94,1 & 56,8 & 39,3 & 73,6 & 53,7 & H. a. \\
\hline 3 & 72,3 & 22,6 & 71,7 & 93,9 & 52,3 & 37,6 & 70,7 & 45,9 & H. a. \\
\hline 4 & 67,3 & 22,3 & 31,2 & 90,4 & 50,5 & 26,1 & 59,4 & 22,4 & H. a. \\
\hline 5 & 56,4 & 22,3 & 27,2 & 91,4 & 47,8 & 30,0 & 65,3 & 15,0 & H. a. \\
\hline 6 & 67,2 & 61,3 & 14,6 & 88,2 & 43,4 & 28,1 & 55,4 & 3,1 & H. a. \\
\hline 7 & 69,8 & 3,2 & 58,5 & 86,7 & 38,3 & 36,1 & 59,4 & 26,8 & 70,0 \\
\hline 8 & 8,3 & 22,6 & 0,7 & 88,5 & 60,2 & 13,8 & 81,3 & 24,5 & 65,0 \\
\hline 9 & 37,4 & 30,0 & 4,9 & 91,9 & 63,8 & 35,0 & 84,3 & 25,5 & 65,0 \\
\hline
\end{tabular}


Окончание таблицы 23

\begin{tabular}{|c|r|r|r|r|r|r|r|r|c|}
\hline 1 & \multicolumn{1}{|c|}{2} & \multicolumn{1}{c|}{3} & \multicolumn{1}{c|}{4} & 5 & 6 & 7 & 8 & 9 & 10 \\
\hline 10 & 6,0 & 6,8 & 53,7 & 81,1 & 32,1 & 20,5 & 41,2 & 31,2 & 60,0 \\
\hline 11 & 14,4 & 6,5 & 54,8 & 81,1 & 36,6 & 30,3 & 51,9 & 35,4 & 60,0 \\
\hline 12 & 13,4 & 23,2 & 54,6 & 88,6 & 45,0 & 31,6 & 72,7 & 30,6 & 71,0 \\
\hline 13 & 13,1 & 1,0 & 48,0 & 88,8 & 40,2 & 32,1 & 69,3 & 28,6 & 68,0 \\
\hline 14 & 12,7 & 15,2 & 34,9 & 85,9 & 36,4 & 22,5 & 65,9 & 12,9 & 65,0 \\
\hline 15 & 6,0 & 3,2 & 51,2 & 92,8 & 42,6 & 66,0 & 73,6 & 5,4 & H. a. \\
\hline 16 & 6,0 & 3,2 & 51,2 & 90,9 & 37,8 & 63,7 & 73,6 & 1,4 & H. a. \\
\hline 17 & 6,0 & 3,2 & 56,1 & 92,8 & 47,4 & 23,9 & 72,2 & 3,0 & H. a. \\
\hline 18 & 6,0 & 3,2 & 51,2 & 93,9 & 42,6 & 23,9 & 74,7 & 1,7 & H. a. \\
\hline
\end{tabular}

Таблицуа 24

Извлечение индивидуальных РЗЭ в сорбент

\begin{tabular}{|c|c|c|c|c|c|c|c|c|}
\hline \multirow[t]{2}{*}{ Опыт } & \multicolumn{8}{|c|}{ Извлечение, отн. \% } \\
\hline & $\mathrm{Y}_{2} \mathrm{O}_{3}$ & $\mathrm{La}_{2} \mathrm{O}_{3}$ & $\mathrm{Ce}_{2} \mathrm{O}_{3}$ & $\mathrm{Pr}_{2} \mathrm{O}_{3}$ & $\mathrm{Nd}_{2} \mathrm{O}_{3}$ & $\mathrm{Sm}_{2} \mathrm{O}_{3}$ & $\mathrm{Eu}_{2} \mathrm{O}_{3}$ & $\mathrm{Gd}_{2} \mathrm{O}_{3}$ \\
\hline 15 & 96,7 & 91,6 & 94,3 & 92,0 & 88,2 & 93,5 & 93,5 & 96,7 \\
\hline 16 & 88,8 & 86,6 & 90,0 & 86,1 & 84,6 & 89,6 & 90,2 & 90,9 \\
\hline 17 & 98,3 & 95,3 & 97,0 & 96,0 & 92,3 & 96,5 & 96,7 & 97,5 \\
\hline 18 & 96,7 & 90,3 & 93,0 & 93,0 & H. a. & 92,2 & 91,8 & 96,3 \\
\hline \multirow[t]{2}{*}{ Опыт } & \multicolumn{8}{|c|}{ Извлечение в сорбент, отн. \% } \\
\hline & $\mathrm{Tb}_{2} \mathrm{O}_{3}$ & $\mathrm{Dy}_{2} \mathrm{O}_{3}$ & $\mathrm{Ho}_{2} \mathrm{O}_{3}$ & $\mathrm{Er}_{2} \mathrm{O}_{3}$ & $\mathrm{Tm}_{2} \mathrm{O}_{3}$ & $\mathrm{Yb}_{2} \mathrm{O}_{3}$ & $\mathrm{Lu}_{2} \mathrm{O}_{3}$ & $\sum \mathrm{Tr}_{2} \mathrm{O}_{3}$ \\
\hline 15 & H. a. & 86,8 & 90,5 & H. a. & H. a. & 87,7 & H. a. & $\geq 92,7$ \\
\hline 16 & H. a. & 85,6 & 81,0 & H. a. & H. a. & 87,7 & H. a. & $\geq 88,1$ \\
\hline 17 & H. a. & 83,2 & 84,8 & H. a. & H. a. & 87,7 & H. a. & $\geq 95,8$ \\
\hline 18 & H. a. & 81,9 & 90,5 & H. a. & H. a. & 87,7 & H. a. & $\geq 91,8$ \\
\hline
\end{tabular}

${ }^{*}$ Содержание РЗЭ анализировали методом атомно-эмиссионной спектрометрии с индукционной плазмой (ICP-ES Plasma 400), не позволявшим из-за низких концентраций достоверно определить содержание $\mathrm{Tb}, \mathrm{Er}, \mathrm{Tm}$ и Lu.

Высокое извлечение РЗЭ в сорбент достигалось лишь при расходе $\mathrm{NaF}$ (расход добавок здесь и далее в пересчёте на фтор) не более 75 г на 1 кг исходного концентрата, при этом имели место достаточно высокая степень заполнения катионообменных центров сорбента и концентрация РЗЭ в нём. Увеличение концентрации фтор-иона в растворе, как и предполагалось, затрудняло поглощение тория в заметно большей степени, чем РЗЭ, однако при высоком извлечении РЗЭ в сорбент торий отделялся в недостаточной степени, а при высокой степени 
отделения тория снижалось извлечение РЗЭ. Одновременное с фтором увеличение концентрации натрия закономерно повышало степень использования сорбента, но снижало содержание в сорбенте РЗЭ.

Введение в раствор $\mathrm{NaF}$ практически не изменило извлечение в сорбент кальция, но привело к снижению извлечения алюминия, титана и железа. При постоянной величине $C_{\mathrm{HNO}_{3}}$ извлечение алюминия, титана и железа снижалось с увеличением концентрации введённого $\mathrm{NaF}$, что объясняется, по-видимому, их переходом в анионные формы при взаимодействии с фтор-ионом.

При небольшом повышении кислотности (ср. опыты 6 и 7) эффективность разделения РЗЭ и тория резко снижалась.

Таким образом, при оптимальной кислотности раствора введение в процессе сорбционной конверсии в азотнокислый раствор фтор-иона в виде $\mathrm{NaF}$ принципиально позволяет отделять торий от Р3Э (см. опыт 6), но извлечение РЗЭ в сорбент недостаточно.

При использовании $\mathrm{NH}_{4} \mathrm{~F}$ (опыты 8-14) концентрация аммония в пульпе возрастала с 0,21 до 0,47-0,87 моль $\cdot \pi^{-1}$. Из-за конкуренции дополнительно введённых катионов $\mathrm{NH}_{4}{ }^{+}$снизились поглощение сорбентом натрия и калия, доля замещённых катионами металлов катионообменных центров сорбента (при её оценке сорбция катионов $\mathrm{NH}_{4}{ }^{+}$не учитывалась) и концентрация РЗЭ в нём. Заметного влияния на поглощение сорбентом щелочноземельных металлов, алюминия, железа и титана не наблюдалось (табл. 23).

С увеличением расхода фтор-иона до 125 г переход в сорбент тория уменьшился в 2,5 раза, а РЗЭ лишь примерно на 14 \%. Это способствовало снижению относительного содержания тория, но не обеспечило необходимую эффективность разделения РЗЭ и тория. Как и при отсутствии содержащих фтор-ион добавок, снижение температуры с 80 до $20{ }^{\circ} \mathrm{C}$ затрудняло процесс сорбционной конверсии и ухудшало эффективность разделения РЗЭ и тория.

При введении $\mathrm{NaF}$ или $\mathrm{NH}_{4} \mathrm{~F}$ РЗЭ цериевой группы сорбировались несколько хуже, чем РЗЭ средней и иттриевой групп.

Высокая эффективность отделения тория с одновременным обеспечением приемлемой степени конверсии была достигнута при снижении $C_{\mathrm{HNO}_{3}}$ до 1 мас. \% и использовании $\mathrm{NH}_{4} \mathrm{HF}_{2}$ (опыт 15), особенно $\mathrm{HF}$ (опыт 17). В последнем случае не вводились ни катион $\mathrm{NH}_{4}{ }^{+}$, ни $\mathrm{Na}^{+}$.

Поглощение сорбентом катионов РЗЭ цериевой группы немного превышало поглощение катионов иттриевой группы (табл. 24). При использовании HF снизился также переход в сорбент титана.

В отличие от конверсии концентратов в сернокислых растворах, сорбент поглощал заметные количества урана, несмотря на значительно более низкую концентрацию его в исходном продукте. Это указывает на то, что уран в присутствии фтор-иона в азотнокислых средах фторсодержащие анионные комплексы не образует. 
Десорбция Р3Э при их содержании 19,5 г $\sum \operatorname{Tr}_{2} \mathrm{O}_{3}$ в 1 л сорбента не должна вызывать затруднений. Полученная при оптимальных условиях маточная пульпа содержала $40 \quad \Gamma^{\cdot} \pi^{-1} \mathrm{H}_{3} \mathrm{PO}_{4}$ и 0,003 мас. \% Th. Она не радиоактивна и может быть утилизирована в основном производстве минеральных удобрений.

Хотя при десорбции РЗЭ сорбент будет получаться в $\mathrm{NH}_{4}{ }^{+}$-форме, в условиях производства по азотнокислотной переработке апатитового концентрата его регенерация в $\mathrm{H}^{+}$-форму не представляет трудностей.

Предположили, что за вводимый в азотнокислый раствор фтор-ион конкурируют торий, фторакцепторные элементы (алюминий, железо, титан) и Р3Э, при этом наиболее прочным является фторалюминатный комплекс, тогда как и в сернокислых растворах [45] $\mathrm{ThF}_{4}$ образуется лишь после того, как алюминий и, возможно, железо «насытятся» фтором.

С целью снижения расхода фтор-иона исследовали возможность предварительного избирательного растворения содержащихся в исходном концентрате примесей. Выщелачивание проводили растворами 2 и 3 мас. \% $\mathrm{HNO}_{3}$ в течение 2 ч при величине отношения Ж : $\mathrm{T}=10: 1$, температуре $80{ }^{\circ} \mathrm{C}$ и постоянном перемешивании. Расход $\mathrm{HNO}_{3}$ составлял соответственно 67 и $100 \%$ от стехиометрически необходимого количества.

Значительная часть алюминия и кальция выщелачивалась достаточно полно уже 2 мас. \% $\mathrm{HNO}_{3}$. Выщелачивание железа и титана было затруднено, а торий практически не выщелачивался. С увеличением расхода и концентрации $\mathrm{HNO}_{3}$ возрастало растворение РЗЭ $\left(1,6 \%\right.$ при $C_{\mathrm{HNO}_{3}}=2$ и $4,0 \%$ при $C_{\mathrm{HNO}_{3}}=$ 3 мас. \%), и если выщелачивание церия невелико $(0,05-0,3 \%)$, то выщелачивание других РЗЭ, особенно средней и иттриевой групп, значительно. Наиболее заметно выщелачивался эрбий: 10,1 и 20,9 \% соответственно растворами 2 и 3 мас. \% $\mathrm{HNO}_{3}$. Убыль массы при обработке 2 и 3 мас. \% $\mathrm{HNO}_{3}$ составила 48,7 и $51,2 \%$, содержание $\sum \operatorname{Tr}_{2} \mathrm{O}_{3}$ в концентрате возросло с 12,2 до 23,4 и 25,6 мас. \%, а суммарное эквивалентное количество катионов уменьшилось с 7,39 до 4,76-4,34 соответственно.

До $80 \%$ выщелоченных РЗЭ извлекалось из раствора сорбцией сульфокатионитом $\mathrm{KУ}-2-8$ чC $\left(\mathrm{NH}_{4}{ }^{+}\right.$-форма) при температуре $20-80{ }^{\circ} \mathrm{C}$ и расходе сорбента $25 \%$ от стехиометрически необходимого для сорбции содержавшихся в растворах катионов металлов, при этом основная часть примесей не сорбировалась.

Таким образом, предварительная обработка редкоземельного концентрата низкоконцентрированными азотнокислыми растворами, включающая выщелачивание и дополнительную сорбцию из раствора выщелачивания, позволяет удалить значительную часть алюминия и кальция 
при относительно небольшой потере РЗЭ, которая в оптимальных условиях составляла лишь 0,32 отн. \%.

Исследование возможности снижения расхода фтора в процессе сорбционной конверсии обогащённого азотнокислотной обработкой концентрата РЗЭ, проводившейся в условиях работы [46], показало, что торий переходил в сорбент хуже, чем РЗЭ и большинство других примесей. Наиболее эффективное разделение РЗЭ и тория наблюдалось при расходе фтора 50-60 г на 1 кг концентрата независимо от температуры процесса $\left(20-80{ }^{\circ} \mathrm{C}\right)$. Увеличение расхода фтор-иона в количестве 100 г на 1 кг концентрата не повысило эффективность отделения тория. Отсутствовала корреляция между количеством введённого фтора и эффективностью разделения РЗЭ и тория, при этом

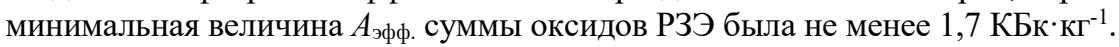

Снижение содержания алюминия в концентрате в 2,5 раза практически не повлияло на эффективность разделения РЗЭ и тория, оценивавшуюся по величине отношения извлечений в сорбент РЗЭ и тория $\varepsilon_{\Sigma \mathrm{Tr}} / \varepsilon_{\mathrm{Th}}$. Извлечение алюминия и железа в сорбент было достаточно высоко (извлечение железа сопоставимо с извлечением РЗЭ). Это указывало на присутствие алюминия и железа во фторсодержащем азотнокислом растворе (по крайней мере, значительной части) в катионной форме, а не в виде анионных фторсодержащих комплексов.

Отсюда заключили, что гипотеза, по которой отделение тория в процессе сорбционной конверсии обусловлено образованием малорастворимого фторида тория, является неточной, а достигнутая высокая степень разделения РЗЭ и тория определяется другим механизмом.

\section{Выводы}

1. Показано, что в процессе сорбционной конверсии фосфатного редкоземельного концентрата введение в азотнокислый раствор содержащих фтор-ион соединений позволяет разделять РЗЭ и торий, при этом РЗЭ количественно сорбируются сульфокатионитом, а торий преимущественно остаётся вместе с фосфором и фтором в маточной пульпе.

2. Исследование влияния состава содержащих фтор-ион соединений и условий проведения процесса на эффективность разделения РЗЭ и тория показало, что: 1) наиболее эффективное разделение при сохранении высокой степени конверсии достигается при использовании $\mathrm{NH}_{4} \mathrm{HF}_{2}$ и $\mathrm{HF}$; 2) эффективное отделение тория от РЗЭ может быть достигнуто также при использовании $\mathrm{NaF}$, но при этом извлечение Р3Э из концентрата в сорбент недостаточно велико; 3) в маточной пульпе остаётся значительная часть ряда примесей, особенно алюминия и титана. 
3. Образующаяся в качестве отхода процесса сорбционной конверсии содержащая торий маточная пульпа нерадиоактивна и может быть утилизирована в основном производстве минеральных удобрений. Предложенный подход исключает образование требующих захоронения радиоактивных отходов с повышенным содержанием тория.

\subsection{3. Разложение с использованием фосфорнокисльх растворов}

Выше показано, что отделение тория возможно сорбционной конверсией фосфатного концентрата в среде содержащего фтор-ион раствора азотной кислоты. Недостатком такого подхода является высокий расход фториона, который в оптимальных условиях составлял 0,87 кг $\mathrm{HF}$ или 1,5 кг $\mathrm{NH}_{4} \mathrm{~F} \cdot \mathrm{HF}$ на 1 кг $\sum \operatorname{Tr}_{2} \mathrm{O}_{3}$ в фосфатном концентрате.

Причиной снижения поглощения тория катионитом являлось образование им анионного комплекса или малодиссоциированной молекулы. В исследовавшемся процессе в качестве возможных лигандов, способствующих образованию таких комплексов тория, могли быть фтор- и/или фосфат-ионы.

При сорбционной конверсии иттрофлюоритового концентрата, проводившейся в низкоконцентрированных азотнокислых и фтороводородных растворах, несмотря на высокую концентрацию фтор-иона (до 1 моль $\pi^{-1}$ ), разделение РЗЭ и тория не наблюдалось (см. выше раздел 2.2).

В фосфорнокислых растворах при сорбционной конверсии апатитового концентрата [47], напротив, имело место разделение РЗЭ и тория. Эффективность разделения возрастала при увеличении концентрации фосфорной кислоты с 5-10 до 38 мас. \%. При сорбционной конверсии монацитового концентрата, проводившейся при температуре $60{ }^{\circ} \mathrm{C}$ в растворе 40 мас. \% фосфорной кислоты, сорбция РЗЭ в 1,5 раза превысила сорбцию тория (табл. 13), а содержание тория в маточном растворе многократно превысило содержание РЗЭ (табл. 14). Предположили, что именно концентрация фосфатионов в азотнокислых растворах влияла на эффективность разделения РЗЭ и тория, и различная устойчивость фосфатных комплексов РЗЭ и тория может быть использована для их разделения.

Исследовали сорбционную конверсию обогащённого фосфатного редкоземельного концентрата в растворе 38 мас. \% $\mathrm{H}_{3} \mathrm{PO}_{4}$. Концентрат содержал (мас. \%): 23,4 $\sum \operatorname{Tr}_{2} \mathrm{O}_{3}, 0,10 \mathrm{Me}_{2} \mathrm{O}, 3,46 \mathrm{CaO}, 0,61 \mathrm{SrO}, 0,80 \mathrm{Al}_{2} \mathrm{O}_{3}$, 1,56 $\mathrm{TiO}_{2}, 6,32 \mathrm{Fe}_{2} \mathrm{O}_{3}, 0,058 \mathrm{ThO}_{2}, 2 \cdot 10^{-4} \mathrm{UO}_{2}, 37,3 \mathrm{P}_{2} \mathrm{O}_{5}, 1,44 \mathrm{~F}, 2,06 \mathrm{SiO}_{2}$ (остальное - вода). Отношение Ж : $\mathrm{T}=15: 1$, в ряде опытов в растворы дополнительно вводили фтор-ион в виде $\mathrm{NH}_{4} \mathrm{~F}$. Опыты проводили при температуре $20{ }^{\circ} \mathrm{C}$, поскольку при сорбционной конверсии апатитового концентрата в среде 38 мас. \% $\mathrm{H}_{3} \mathrm{PO}_{4}$ при температуре $80{ }^{\circ} \mathrm{C}$ количество 
поглощаемого сульфокатионитом тория возрастает [47]. Условия проведения опытов и основные показатели по эффективности конверсии приведены в табл. 25.

Таблица 25

Условия проведения опытов и основные показатели по эффективности конверсии

\begin{tabular}{|c|c|c|c|c|c|c|c|c|}
\hline Опыт & $\begin{array}{c}\text { Фтор, г/кг } \\
\text { концентрата }\end{array}$ & $\beta, \%$ & $\begin{array}{c}t, \\
{ }^{\circ} \mathrm{C}\end{array}$ & $\begin{array}{c}\text { Время, } \\
\text { ч }\end{array}$ & $\begin{array}{c}\text { Масса остатка, } \\
\text { отн. \% }\end{array}$ & $\varepsilon_{\Sigma \text { Гт }}, \%$ & $\varepsilon_{\text {Th, }} \%$ & $\varepsilon_{\Sigma \text { Тт }} / \varepsilon_{\text {Th }}$ \\
\hline 1 & 0 & 123 & 20 & 4 & 41,4 & 61,6 & 14,6 & 4,22 \\
\hline 2 & 15 & 123 & 20 & 4 & 57,6 & 59,4 & 4,47 & 13,3 \\
\hline 3 & 50 & 123 & 20 & 4 & 58,0 & 52,7 & 3,34 & 15,8 \\
\hline 4 & 0 & 200 & 20 & 4 & 45,0 & 61,0 & 6,70 & 9,1 \\
\hline
\end{tabular}

Из данных табл. 25 видно, что эффективность конверсии в фосфорнокислой среде значительно уменьшилась по сравнению с конверсией в азотнокислой среде. При этом, как показывают данные табл. 26, снижение извлечения РЗЭ в сорбент главным образом определялось церием, сорбция которого не превышала 24,3 отн. \%. Хорошо поглощались сорбентом щелочноземельные металлы. В отличие от конверсии в азотнокислой среде титан, алюминий, железо и торий, как видно из данных табл. 26 и 27, накапливались в растворе. Относительно небольшое количество попадавшего в сорбент тория определяло хорошую для практического применения степень разделения РЗЭ и тория. При этом $A_{\text {эфф. }}$ растворов не превышала 0,125 КБк к к-1, т. е. работа с ними в производственных условиях возможна без ограничений.

Увеличение расхода сорбента до 200 \% от стехиометрически необходимого (опыт 4) приводило к некоторому повышению извлечения всех РЗЭ, кроме церия. Добавка в фосфорнокислый раствор фтор-иона в виде $\mathrm{NH}_{4} \mathrm{~F}$ при прочих равных условиях вызывала снижение извлечения в сорбент и РЗЭ, и тория, но эффективность разделения РЗЭ и тория возрастала. Это позволяет предположить образование в таких растворах фтор-фосфатных комплексов тория.

Полученные остатки по сравнению с исходным концентратом характеризовались (табл. 28): 1) повышенным содержанием церия, особенно в опытах без использования добавки $\mathrm{NH}_{4} \mathrm{~F}$, где содержание $\mathrm{Ce}_{2} \mathrm{O}_{3}$ в $\sum \mathrm{Tr}_{2} \mathrm{O}_{3}$ составило 93,7-95,4 мас. \%; 2) пониженной, хотя и достаточно высокой, концентрацией $\mathrm{ThO}_{2}$ относительно $\left.\sum \mathrm{Tr}_{2} \mathrm{O}_{3} ; 3\right)$ пониженным содержанием титана и железа. 
Извлечение компонентов в сорбент

\begin{tabular}{|c|c|c|c|c|c|c|c|c|c|c|}
\hline \multirow{2}{*}{ Опыт } & \multicolumn{10}{|c|}{ Извлечение, отн. \% } \\
\hline & $\mathrm{Y}$ & \multicolumn{2}{|c|}{$\mathrm{La}$} & $\mathrm{Ce}$ & $\operatorname{Pr}$ & $\mathrm{Nd}$ & \multicolumn{2}{|c|}{$\mathrm{Sm}$} & $\mathrm{Eu}$ & $\overline{\mathrm{Gd}}$ \\
\hline 1 & 88,0 & \multicolumn{2}{|c|}{96,0} & 24,3 & 93,1 & 92,9 & \multicolumn{2}{|c|}{89,2} & 90,2 & 82,1 \\
\hline 2 & 87,7 & \multicolumn{2}{|c|}{94,5} & 20,8 & 92,0 & 92,1 & \multicolumn{2}{|c|}{88,6} & 88,2 & 81,14 \\
\hline 3 & 86,7 & \multicolumn{2}{|c|}{94,7} & 6,8 & 91,6 & 91,3 & \multicolumn{2}{|c|}{87,6} & 87,0 & 78,8 \\
\hline \multirow[t]{2}{*}{4} & 95,5 & \multicolumn{2}{|c|}{97,8} & 18,9 & 97,1 & 96,9 & \multicolumn{2}{|c|}{96,0} & 95,7 & 87,0 \\
\hline & $\mathrm{Tb}$ & \multicolumn{2}{|c|}{ Dy } & Ho & $\mathrm{Er}$ & $\mathrm{Tm}$ & \multicolumn{2}{|c|}{$\mathrm{Yb}$} & $\mathrm{Lu}$ & $\sum \operatorname{Tr}$ \\
\hline 1 & 87,2 & \multicolumn{2}{|c|}{88,2} & 87,9 & 87,6 & 86,4 & \multicolumn{2}{|c|}{81,4} & 79,6 & 61,6 \\
\hline 2 & 86,6 & \multicolumn{2}{|c|}{87,7} & 87,2 & 87,0 & 85,8 & \multicolumn{2}{|c|}{82,0} & 82,0 & 59,4 \\
\hline 3 & 85,2 & \multicolumn{2}{|c|}{86,6} & 85,6 & 85,4 & 84,0 & 80 & & 81,1 & 52,7 \\
\hline 4 & 93,6 & 95 & & 95,4 & 95,2 & 94,7 & & & 93,2 & 61,0 \\
\hline & $\mathrm{Na}$ & $\mathrm{K}$ & $\mathrm{Mg}$ & $\mathrm{Ca}$ & $\mathrm{Sr}$ & $\mathrm{Al}$ & $\mathrm{Ti}$ & $\mathrm{Fe}$ & Th & $\mathrm{U}$ \\
\hline 1 & 66,4 & 59,8 & 72,8 & 95,6 & 96,1 & 37,4 & 0,94 & 29,5 & 14,6 & 17,6 \\
\hline 2 & 53,7 & 60,2 & 24,2 & 94,6 & 94,2 & 36,6 & 1,21 & 25,5 & 4,45 & 29,4 \\
\hline 3 & 27,3 & 14,4 & 40,4 & 94,6 & 94,3 & 28,7 & 0,53 & 22,6 & 3,34 & 28,7 \\
\hline 4 & 40,5 & 63,2 & 76,4 & 98,6 & 97,1 & 49,5 & 3,30 & 29,1 & 6,69 & 19,6 \\
\hline
\end{tabular}

Таблица 27

Концентрация компонентов в маточных растворах

\begin{tabular}{|c|c|c|c|c|c|c|c|c|c|c|c|}
\hline \multirow{2}{*}{ Опыт } & \multicolumn{11}{|c|}{ Концентрация, мг·л ${ }^{-1}$} \\
\hline & $\mathrm{Y}_{2} \mathrm{O}_{3}$ & \multicolumn{2}{|c|}{$\mathrm{La}_{2} \mathrm{O}_{3}$} & $\mathrm{Ce}_{2} \mathrm{O}_{3}{ }^{*}$ & $\mathrm{Pr}_{2} \mathrm{O}_{3}$ & $\mathrm{Nd}_{2} \mathrm{O}_{3}$ & \multicolumn{2}{|c|}{$\mathrm{Sm}_{2} \mathrm{O}_{3}$} & \multicolumn{2}{|c|}{$\mathrm{Eu}_{2} \mathrm{O}_{3}$} & $\mathrm{Gd}_{2} \mathrm{O}_{3}$ \\
\hline 1 & 30,22 & \multicolumn{2}{|c|}{75,73} & 296,0 & 29,35 & 120,6 & \multicolumn{2}{|c|}{27,17} & \multicolumn{2}{|c|}{8,54} & 24,77 \\
\hline 2 & 31,52 & \multicolumn{2}{|c|}{80,37} & 346,4 & 30,89 & 118,6 & \multicolumn{2}{|c|}{28,04} & \multicolumn{2}{|c|}{8,82} & 25,97 \\
\hline 3 & 33,41 & \multicolumn{2}{|c|}{87,96} & $\frac{17,7}{226,6}$ & 33,66 & 143,4 & \multicolumn{2}{|c|}{30,48} & \multicolumn{2}{|c|}{9,60} & 28,0 \\
\hline \multirow[t]{2}{*}{4} & 9,78 & \multicolumn{2}{|c|}{24,88} & 181,6 & 8,15 & 33,7 & \multicolumn{2}{|c|}{8,32} & \multicolumn{2}{|c|}{2,72} & 7,86 \\
\hline & $\mathrm{Tb}_{2} \mathrm{O}_{3}$ & \multicolumn{2}{|c|}{$\mathrm{Dy}_{2} \mathrm{O}_{3}$} & $\mathrm{Ho}_{2} \mathrm{O}_{3}$ & $\mathrm{Er}_{2} \mathrm{O}_{3}$ & $\mathrm{Tm}_{2} \mathrm{O}_{3}$ & \multicolumn{2}{|c|}{$\mathrm{Yb}_{2} \mathrm{O}_{3}$} & \multicolumn{2}{|c|}{$\mathrm{Lu}_{2} \mathrm{O}_{3}$} & $\sum \mathrm{Tr}_{2} \mathrm{O}_{3}$ \\
\hline 1 & 3,03 & \multicolumn{2}{|c|}{11,73} & 1,52 & 2,82 & 0,24 & & & & 14 & 633,2 \\
\hline 2 & 3,16 & 11 , & & 1,55 & 2,81 & 0,25 & & & & 14 & 691,7 \\
\hline 3 & 3,42 & 13, & & 1,75 & 3,21 & 0,26 & & & & 15 & 616,6 \\
\hline 4 & 0,99 & 3, & & 0,50 & 0,895 & 0,074 & & 42 & & 44 & 283,8 \\
\hline & $\mathrm{Na}_{2} \mathrm{O}$ & $\mathrm{K}_{2} \mathrm{O}$ & $\mathrm{MgO}$ & $\mathrm{CaO}$ & $\mathrm{SrO}$ & $\mathrm{Al}_{2} \mathrm{O}_{3}$ & $\mathrm{TiO}_{2}$ & $\mathrm{Fe}_{2} \mathrm{I}$ & & $\mathrm{ThO}_{2}$ & $\mathrm{UO}_{2}$ \\
\hline 1 & 17,30 & 8,76 & 3,56 & $\overline{106,4}$ & 12,11 & 284,5 & 908 & 348 & & 39,62 & \begin{tabular}{|l|l|}
2 & 0,071 \\
\end{tabular} \\
\hline 2 & 19,49 & 6,17 & 3,76 & 134,7 & 13,34 & 282,2 & 878 & 364 & & 38,35 & \begin{tabular}{|l|l}
5 & 0,117 \\
\end{tabular} \\
\hline 3 & 28,35 & 16,34 & 3,64 & 130,7 & 14,45 & 301,5 & 730 & 352 & & 34,22 & \begin{tabular}{|l|l}
2 & 0,054
\end{tabular} \\
\hline 4 & 24,13 & 6,25 & 3,37 & 37,10 & 5,42 & 223,7 & 973 & 346 & & 31,60 & \begin{tabular}{|l|l|}
0 & 0,073 \\
\end{tabular} \\
\hline
\end{tabular}

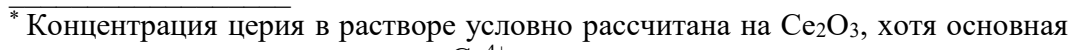
часть церия присутствует в виде $\mathrm{Ce}^{4+}$. 
Характеристика остатков

\begin{tabular}{|c|c|r|c|c|c|c|c|c|c|c|c|}
\hline \multirow{2}{*}{ Опыт } & Мacca, & \multicolumn{10}{|c|}{ Содержание, мас. \% } \\
\cline { 3 - 13 } & отн. \% & $\mathrm{CaO}$ & $\mathrm{SrO}$ & $\mathrm{Al}_{2} \mathrm{O}_{3}$ & $\mathrm{TiO}_{2}$ & $\mathrm{Fe}_{2} \mathrm{O}_{3}$ & $\mathrm{ThO}_{2}$ & $\mathrm{Ce}_{2} \mathrm{O}_{3}$ & $\sum \mathrm{Tr}_{2} \mathrm{O}_{3}$ & $\mathrm{P}_{2} \mathrm{O}_{5}$ & $\mathrm{~F}$ \\
\hline 1 & 41,4 & 0,06 & 0,03 & 0,12 & 1,03 & 0,51 & 0,03 & 21,6 & 22,6 & 26,9 & 0,78 \\
\hline 2 & 57,6 & 0,036 & 0,04 & 0,10 & 0,81 & 0,47 & 0,026 & 16,1 & 17,1 & 20,0 & 0,49 \\
\hline 3 & 58,0 & 0,05 & 0,04 & 0,15 & 1,21 & 1,18 & 0,038 & 19,3 & 20,3 & 29,5 & 0,56 \\
\hline 4 & 45,0 & 0,005 & 0,03 & 0,11 & 0,96 & 0,60 & 0,052 & 21,7 & 22,3 & 23,8 & 0,50 \\
\hline
\end{tabular}

Таким образом, конверсия в фосфорнокислой среде позволяет разделять РЗЭ и торий, при этом РЗЭ, кроме церия, эффективно поглощаются сорбентом, а торий накапливается в фосфорнокислом растворе в не сорбируемой катионитом форме - анионном комплексе или практически не диссоциированной молекуле. Введение небольшой добавки фтор-иона способствует повышению эффективности разделения РЗЭ и тория.

Предположили, что наиболее вероятной причиной «аномального» поведения церия являлось постепенное окисление кислородом воздуха $\mathrm{Ce}^{3+}$ в $\mathrm{Ce}^{4+}$ при хранении фосфатного концентрата в воздушной атмосфере. Для проверки обогащённые церием остатки опытов 1-4 (табл. 1) объединили и обработали содержащим пероксид водорода фосфорнокислым раствором при $20^{\circ} \mathrm{C}$ в присутствии сульфокатионита $(\beta=123 \%$, Ж : Т $=15: 1$, время 4 ч). При этом наблюдали выделение пузырьков кислорода по реакции:

$$
\mathrm{Ce}^{4+}+\mathrm{H}_{2} \mathrm{O}_{2} \rightarrow \mathrm{Ce}^{3+}+\mathrm{H}_{2} \mathrm{O}+0,5 \mathrm{O}_{2} \uparrow \text {. }
$$

Извлечение в сорбент РЗЭ, в том числе церия, составило 93,8\%. Остаток представлял собой продукт на основе гидратированного кремнезёма, содержавший (мас. \%): 2,95 $\sum \mathrm{Tr}_{2} \mathrm{O}_{3}, 0,72 \mathrm{TiO}_{2}$, по 0,12 $\mathrm{Al}_{2} \mathrm{O}_{3}$ и $\mathrm{Fe}_{2} \mathrm{O}_{3}, \leq 0,05$ каждого из оксидов щелочных и щелочноземельных элементов, $0,016 \mathrm{ThO}_{2}$ и $0,0002 \mathrm{UO}_{2}$. Потери РЗЭ с твёрдым остатком составили $\approx 4 \%$. Лишь $2,7 \%$ тория попало в сорбент, а основная часть (80,2 \%) перешла в маточный раствор. Величина $\varepsilon_{\Sigma \mathrm{Tr}} / \varepsilon_{\mathrm{Th}}$ составила 34,7 , т. е. имело место эффективное отделение

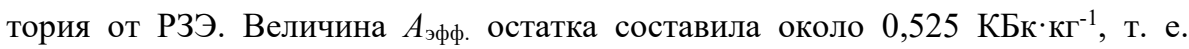
в производственных условиях работа с ним может проводиться без ограничений.

В таблице 29 приведено содержание основных металлов в фосфорнокислом растворе. Основные примеси в маточном растворе - церий, титан, железо. Достаточно высокое содержание церия, вероятно, связано с частичным присутствием в виде $\mathrm{Ce}^{4+}$, который, аналогично торию, образует

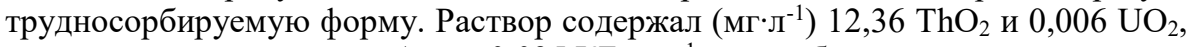
что определяло величину $A_{\text {эфф. }} \approx 0,035$ КБк $\kappa^{*} \Gamma^{-1}$, т. е. работа и с раствором может проводиться без ограничений. 
Таблица 29

Концентрация компонентов в маточном растворе, полученном при сорбционной конверсии обогащённых церием фосфатных остатков

\begin{tabular}{|c|c|c|c|c|c|c|c|c|c|}
\hline \multicolumn{10}{|c|}{ Концентрация, мг·л ${ }^{-1}$} \\
\hline $\mathrm{Y}_{2} \mathrm{O}_{3}$ & $\mathrm{La}_{2} \mathrm{O}_{3}$ & \multicolumn{2}{|c|}{$\mathrm{Ce}_{2} \mathrm{O}_{3}$} & $\mathrm{Pr}_{2} \mathrm{O}_{3}$ & $\mathrm{Nd}_{2} \mathrm{O}_{3}$ & $\mathrm{Sm}_{2} \mathrm{O}_{3}$ & \multicolumn{2}{|c|}{$\mathrm{Eu}_{2} \mathrm{O}_{3}$} & $\mathrm{Gd}_{2} \mathrm{O}_{3}$ \\
\hline 1,11 & 2,89 & \multicolumn{2}{|c|}{242,5} & 0,97 & 4,12 & 0,95 & \multicolumn{2}{|c|}{0,27} & 2,57 \\
\hline $\mathrm{Tb}_{2} \mathrm{O}_{3}$ & $\mathrm{Dy}_{2} \mathrm{O}$ & \multicolumn{2}{|c|}{$\mathrm{Ho}_{2} \mathrm{O}_{3}$} & $\mathrm{Er}_{2} \mathrm{O}_{3}$ & $\mathrm{Tm}_{2} \mathrm{O}_{3}$ & $\mathrm{Yb}_{2} \mathrm{O}_{3}$ & \multicolumn{2}{|c|}{$\mathrm{Lu}_{2} \mathrm{O}_{3}$} & $\sum \operatorname{Tr}_{2} \mathrm{O}_{3}$ \\
\hline 0,14 & 0,50 & \multicolumn{2}{|c|}{0,05} & 0,12 & 0,01 & 0,06 & \multicolumn{2}{|c|}{0,006} & 256,3 \\
\hline $\mathrm{Na}_{2} \mathrm{O}$ & $\mathrm{K}_{2} \mathrm{O}$ & $\mathrm{MgO}$ & $\mathrm{CaO}$ & $\mathrm{SrO}$ & $\mathrm{Al}_{2} \mathrm{O}_{3}$ & $\mathrm{TiO}_{2}$ & $\mathrm{Fe}_{2} \mathrm{O}_{3}$ & $\mathrm{ThO}_{2}$ & $\mathrm{UO}_{2}$ \\
\hline 95,6 & 1,1 & 4.3 & 0,25 & 0,29 & 21,2 & 4142 & 144,4 & 12,4 & 0,006 \\
\hline
\end{tabular}

Исследовали влияние концентрации фосфорной кислоты и температуры на эффективность разделения РЗЭ и тория в процессе сорбционной конверсии фосфатного редкоземельного концентрата. Условия проведения опытов: расход сорбента в $\mathrm{H}^{+}$-форме $132 \%$ от стехиометрически необходимого, пероксида водорода в виде 30 мас. \% раствора $650 \%$ от стехиометрически необходимого, $C_{\mathrm{H}_{3} \mathrm{PO}_{4}}=15-38$ мас. \%, температура $20-60{ }^{\circ} \mathrm{C}$, длительность процесса 4 ч. Результаты опытов при $20^{\circ} \mathrm{C}$ приведены в табл. 30-32.

Таблииа 30

Влияние концентрации фосфорной кислоты на извлечение компонентов в сорбент при $20^{\circ} \mathrm{C}$

\begin{tabular}{|c|c|c|c|c|c|c|c|c|c|c|c|}
\hline \multirow{2}{*}{ Опыт } & \multirow{2}{*}{$\begin{array}{l}C_{\mathrm{H}_{3} \mathrm{PO}_{4}}, \\
\text { мac. \% }\end{array}$} & \multicolumn{10}{|c|}{ Извлечение, отн. \% } \\
\hline & & $\mathrm{Y}$ & \multicolumn{2}{|c|}{$\mathrm{La}$} & $\mathrm{Ce}$ & $\operatorname{Pr}$ & $\mathrm{Nd}$ & \multicolumn{2}{|c|}{$\mathrm{Sm}$} & $\mathrm{Eu}$ & $\mathrm{Gd}$ \\
\hline 1 & 15 & 99,1 & 99,6 & & 99,4 & 99,4 & 99,4 & \multicolumn{2}{|c|}{99,0} & 99,1 & 99,1 \\
\hline 2 & 20 & 96,9 & \multicolumn{2}{|c|}{99,0} & 98,7 & 98,6 & 98,5 & \multicolumn{2}{|c|}{97,3} & 97,4 & 97,7 \\
\hline 3 & 25 & 95,4 & \multicolumn{2}{|c|}{98,6} & 98,0 & 97,8 & 97,7 & \multicolumn{2}{|c|}{95,9} & 96,2 & 96,7 \\
\hline \multirow[t]{2}{*}{4} & 38 & 86,1 & \multicolumn{2}{|c|}{95,8} & 94,1 & 93,3 & 92,8 & \multicolumn{2}{|c|}{87,7} & 89,0 & 90,5 \\
\hline & & $\mathrm{Tb}$ & \multicolumn{2}{|c|}{ Dy } & Ho & Er & $\mathrm{Tm}$ & \multicolumn{2}{|c|}{$\mathrm{Yb}$} & $\mathrm{Lu}$ & $\sum \operatorname{Tr}$ \\
\hline 1 & 15 & 99,1 & \multicolumn{2}{|c|}{99,0} & 99,0 & 98,9 & 98,8 & \multicolumn{2}{|c|}{98,6} & 99,1 & 99,4 \\
\hline 2 & 20 & 97,6 & \multicolumn{2}{|c|}{97,0} & 97,2 & 97,0 & 97,0 & \multicolumn{2}{|c|}{96,3} & 6,8 & 98,6 \\
\hline 3 & 25 & 96,5 & 95,8 & & 96,0 & 95,6 & 95,5 & $\overline{94}$ & & 55,1 & 97,9 \\
\hline 4 & 38 & 90,8 & 89, & & 88,9 & 88,6 & 87,6 & 85 & & 37,5 & 93,8 \\
\hline & & $\mathrm{Na}$ & $\mathrm{K}$ & $\mathrm{Mg}$ & $\mathrm{Ca}$ & $\mathrm{Sr}$ & $\mathrm{Al}$ & $\mathrm{Ti}$ & $\mathrm{Fe}$ & Th & $\mathrm{U}$ \\
\hline 1 & 15 & 80,0 & 49,9 & 79,6 & 84,4 & 98,6 & 64,0 & 1,43 & 44,0 & 43,2 & 26,8 \\
\hline 2 & 20 & 78,5 & 47,9 & 74,0 & 80,8 & 97,9 & 53,7 & 2,03 & 16,1 & 11,5 & 14,8 \\
\hline 3 & 25 & 74,5 & 37,6 & 68,4 & 75,3 & 97,4 & 48,0 & 1,90 & 20,1 & 9,31 & 19,1 \\
\hline 4 & 38 & 83,9 & 54,1 & 81,8 & 86,6 & 95,8 & 53,3 & 1,77 & 24,3 & 6,40 & 30,6 \\
\hline
\end{tabular}


Концентрация компонентов в маточных растворах

\begin{tabular}{|c|c|c|c|c|c|c|c|c|c|c|c|}
\hline \multirow{2}{*}{ Опыт } & \multicolumn{11}{|c|}{ Концентрация, мг·л ${ }^{-1}$} \\
\hline & $\mathrm{Y}_{2} \mathrm{O}_{3}$ & \multicolumn{2}{|c|}{$\mathrm{La}_{2} \mathrm{O}_{3}$} & $\mathrm{Ce}_{2} \mathrm{O}_{3}$ & $\mathrm{Pr}_{2} \mathrm{O}_{3}$ & $\mathrm{Nd}_{2} \mathrm{O}_{3}$ & \multicolumn{2}{|c|}{$\mathrm{Sm}_{2} \mathrm{O}_{3}$} & \multicolumn{2}{|c|}{$\mathrm{Eu}_{2} \mathrm{O}_{3}$} & $\mathrm{Gd}_{2} \mathrm{O}_{3}$ \\
\hline 1 & 2,43 & \multicolumn{2}{|c|}{8,72} & 20,9 & 2,04 & 8,46 & \multicolumn{2}{|c|}{2,34} & \multicolumn{2}{|c|}{0,69} & 2,20 \\
\hline 2 & 9,89 & \multicolumn{2}{|c|}{31,9} & 77,9 & 8,61 & 34,4 & \multicolumn{2}{|c|}{8,51} & \multicolumn{2}{|c|}{2,45} & 7,58 \\
\hline 3 & 14,7 & \multicolumn{2}{|c|}{50,8} & 126 & 13,7 & 57,7 & \multicolumn{2}{|c|}{13,2} & \multicolumn{2}{|c|}{3,72} & 11,4 \\
\hline \multirow[t]{2}{*}{$\frac{3}{4}$} & 51,4 & \multicolumn{2}{|c|}{191} & 492 & 53,0 & 216 & \multicolumn{2}{|c|}{46,3} & \multicolumn{2}{|c|}{12,5} & 38,5 \\
\hline & $\mathrm{Tb}_{2} \mathrm{O}_{3}$ & \multicolumn{2}{|c|}{$\mathrm{Dy}_{2} \mathrm{O}_{3}$} & $\mathrm{Ho}_{2} \mathrm{O}_{3}$ & $\mathrm{Er}_{2} \mathrm{O}_{3}$ & $\mathrm{Tm}_{2} \mathrm{O}_{3}$ & \multicolumn{2}{|c|}{$\mathrm{Yb}_{2} \mathrm{O}_{3}$} & \multicolumn{2}{|c|}{$\mathrm{Lu}_{2} \mathrm{O}_{3}$} & $\sum \mathrm{Tr}_{2} \mathrm{O}_{3}$ \\
\hline 1 & 0,25 & \multicolumn{2}{|c|}{1,06} & 0,13 & 0,23 & 0,018 & \multicolumn{2}{|c|}{0,092} & \multicolumn{2}{|c|}{0,008} & 49,5 \\
\hline 2 & 0,86 & \multicolumn{2}{|c|}{3,57} & 0,43 & 0,80 & 0,061 & \multicolumn{2}{|c|}{0,30} & \multicolumn{2}{|c|}{0,027} & 187 \\
\hline 3 & 1,29 & 5,1 & & 0,63 & 1,20 & 0,092 & 0 & & & 48 & 300 \\
\hline 4 & 3,89 & 15 , & & 1,95 & 3,57 & 0,297 & 1, & & & 32 & 1128 \\
\hline & $\mathrm{Na}_{2} \mathrm{O}$ & $\mathrm{K}_{2} \mathrm{O}$ & $\mathrm{MgO}$ & \begin{tabular}{l|l}
$\mathrm{O}$ & $\mathrm{CaO}$ \\
\end{tabular} & $\mathrm{SrO}$ & $\mathrm{Al}_{2} \mathrm{O}_{3}$ & $\mathrm{TiO}_{2}$ & $\mathrm{Fe}_{2}$ & & $\mathrm{ThO}_{2}$ & $\mathrm{UO}_{2}$ \\
\hline 1 & 12,6 & 2,57 & 1,09 & 62,5 & 3,87 & 147 & 1070 & 27 & & 28,3 & 0,074 \\
\hline 2 & 14,9 & 3,56 & 1,87 & 141 & 8,11 & 209 & 1097 & 41 & & 43,2 & 0,088 \\
\hline 3 & 17,8 & 4,13 & 1,72 & 161 & 9,86 & 228 & 1087 & 35 & & 44,4 & 0,081 \\
\hline 4 & 15,3 & 6,74 & 4,50 & 312 & 20,6 & 236 & 1220 & 42 & & 52,1 & 0,067 \\
\hline
\end{tabular}

Таблиияа 32

Характеристика остатков

\begin{tabular}{|c|c|c|c|c|c|c|c|c|c|c|c|}
\hline \multirow{2}{*}{ Опыт } & Мacca, & \multicolumn{10}{|c|}{ Содержание, мас. \% } \\
\cline { 3 - 12 } & отн. \% & $\mathrm{CaO}$ & $\mathrm{SrO}$ & $\mathrm{Al}_{2} \mathrm{O}_{3}$ & $\mathrm{TiO}_{2}$ & $\mathrm{Fe}_{2} \mathrm{O}_{3}$ & $\mathrm{ThO}_{2}$ & $\mathrm{UO}_{2}$ & $\sum \mathrm{Tr}_{2} \mathrm{O}_{3}$ & $\mathrm{P}_{2} \mathrm{O}_{5}$ & $\mathrm{~F}$ \\
\hline 1 & 19,0 & 2,93 & 0,024 & 0,27 & 0,93 & 1,42 & 0,004 & $7 \cdot 10^{-5}$ & 0,42 & 9,8 & 1,29 \\
\hline 2 & 17,0 & 3,45 & 0,022 & 0,22 & 0,73 & 1,21 & 0,014 & $7 \cdot 10^{-5}$ & 0,51 & 2,7 & 1,47 \\
\hline 3 & 15,0 & 5,24 & 0,032 & 0,36 & 0,95 & 1,50 & 0,015 & $11 \cdot 10^{-5}$ & 0,68 & 2,6 & 1,36 \\
\hline 4 & 14,0 & 0,95 & 0,028 & 0,26 & 0,92 & 0,92 & 0,005 & $2 \cdot 10^{-4}$ & 0,96 & 12,0 & 1,14 \\
\hline
\end{tabular}

Видно, что добавка пероксида водорода обеспечила переход церия в сорбент и, как следствие, высокую эффективность сорбционной конверсии, постепенно снижавшуюся при увеличении кислотности раствора. Величина $\varepsilon_{\Sigma \mathrm{Tr}} / \varepsilon_{\mathrm{Th}}$, напротив, при увеличении кислотности раствора возрастала с 2,3 при $C_{\mathrm{H}_{3} \mathrm{PO}_{4}}=15$ мас. \% до 14,6 при $C_{\mathrm{H}_{3} \mathrm{PO}_{4}}=38$ мас. \%.

При $20^{\circ} \mathrm{C}$ и $C_{\mathrm{H}_{3} \mathrm{PO}_{4}}=20-25$ мас. \% получены высокая степень конверсии (извлечение суммы РЗЭ в сорбент 97,9-98,6 \%, в том числе извлечение РЗЭ иттриевой группы $\geq 94,4-96,3 \%$ и д достаточная степень разделения 
$\left(\varepsilon_{\Sigma \mathrm{Tr}} / \varepsilon_{\mathrm{Th}}=8,55-10,5\right)$. При этом в сорбенте содержание тория относительно $\sum \mathrm{Tr}_{2} \mathrm{O}_{3}$ составит 0,024-0,029 мас. \%, что при его последующей переработке позволит получать редкоземельные материалы с $A_{\text {эфф. }} \leq 0,74$ КБк·кг ${ }^{-1}$, поскольку

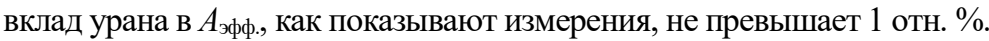

На операции сорбционной конверсии отделялся не только торий, но и титан, а также значительная часть железа и алюминия. Эти примеси накапливались в маточных растворах (табл. 31) из-за образования ими анионных комплексов или недиссоциированных молекул. В оптимальных условиях 1 л сорбента содержал металлов в пересчёте на оксиды (г): 28,75 $\sum \operatorname{Tr}_{2} \mathrm{O}_{3}, 0,075 \mathrm{Na}_{2} \mathrm{O}+\mathrm{K}_{2} \mathrm{O} \mathrm{Me} 2 \mathrm{O}, 3,4 \mathrm{CaO}, 0,75 \mathrm{SrO}, 0,5 \mathrm{Al}_{2} \mathrm{O}_{3}, 0,038 \mathrm{TiO}_{2}$, $1,42 \mathrm{Fe}_{2} \mathrm{O}_{3}, 0,0072 \mathrm{ThO}_{2}, 0,000042 \mathrm{UO}_{2}$.

Неразлагавшиеся остатки представляли собой нерадиоактивные продукты на основе гидратированного кремнезёма (табл. 32). Их утилизация не представляет трудностей.

При конверсии в среде 20 мас. \% $\mathrm{H}_{3} \mathrm{PO}_{4}$ повышение температуры до $40-60{ }^{\circ} \mathrm{C}$ обеспечивало высокую эффективность конверсии (извлечение РЗЭ в сорбент 98,4-98,9 \%), но резко ухудшалось отделение тория: величина отношения $\varepsilon_{\Sigma \mathrm{Tr}} / \varepsilon_{\mathrm{Th}}$ составляла 2,06 при $40{ }^{\circ} \mathrm{C}$ и 1,86 при $60{ }^{\circ} \mathrm{C}$. Повышение сорбции тория при увеличении температуры связано с разрушением образуемых им при $20{ }^{\circ} \mathrm{C}$ не сорбируемых сульфокатионитом форм.

\section{Выводы}

1. Показана возможность отделения тория от РЗЭ в процессе сорбционной конверсии в фосфорнокислых растворах фосфатного редкоземельного концентрата, получаемого при азотнокислотной переработке апатита. Оптимальными условиями проведения сорбционной конверсии в фосфорнокислых растворах, обеспечивающими эффективное отделение тория, являются концентрация $\mathrm{H}_{3} \mathrm{PO}_{4}$ в растворе $20-25$ мас. \% и температура $20{ }^{\circ} \mathrm{C}$.

Увеличение концентрации фосфорной кислоты до 38 мас. \% повышает эффективность разделения РЗЭ и тория, но уменьшает извлечение РЗЭ в сорбент. Увеличение температуры процесса до $40{ }^{\circ} \mathrm{C}$ резко снижает эффективность разделения РЗЭ и тория.

2. Торий накапливается в маточном растворе из-за образования анионного комплекса или нейтральной молекулы, которые при снижении концентрации фосфорной кислоты и повышении температуры раствора распадаются с образованием катионного комплекса тория.

3. В маточную пульпу кроме тория попадают кремнезём и основная часть титана, железа, алюминия, урана. 
4. Введение в фосфорнокислый раствор небольших добавок фтор-иона повышает эффективность разделения редкоземельных элементов и тория, но не обязательно для получения нерадиоактивного редкоземельного продукта.

5. При хранении фосфатного концентрата редкоземельных элементов на воздухе происходит постепенное окисление церия, в результате чего затрудняется растворение фосфатного концентрата в фосфорнокислом растворе и резко снижается извлечение РЗЭ, главным образом церия, в сорбент. Введение пероксида водорода в фосфорнокислый раствор обеспечивает полноту растворения фосфатного концентрата, не снижая эффективность разделения РЗЭ и тория.

6. В процессе сорбционной конверсии исключается образование промежуточных и конечных продуктов $\mathrm{c}$ повышенной концентрацией природных радионуклидов. 


\section{4. СЕРНОКИСЛОТНОЕ РАЗЛОЖЕНИЕ ФТОР-ФОСФАТНОГО КОНЦЕНТРАТА, ОСАЖДЁННОГО ИЗ ЭКСТРАКЦИОННОЙ ФОСФОРНОЙ КИСЛОТЫ ДИГИДРАТНОГО ПРОЦЕССА}

Из экстракционной фосфорной кислоты дигидратного процесса РЗЭ могут быть извлечены методом сорбции [24, 48]. Одновременно возможно отделение тория [49]. Для реализации сорбционного выделения РЗЭ требуется большой объём оборудования, который необходимо размещать на имеющихся производственных площадях, что делает проблематичным его реализацию на функционирующих производствах.

Найдено, что при введении в экстракционную фосфорную кислоту фторидных реагентов $\left(\mathrm{NH}_{4} \mathrm{~F} \cdot \mathrm{HF}, \mathrm{NH}_{4} \mathrm{~F}\right)$ осаждается $\geq 95 \%$ Р3Э [50]. Для реализации этого метода требуется значительно меньший объём оборудования. Переработка осаждаемых концентратов возможна на отдельной производственной площадке.

Получающиеся фтор-фосфатные остатки содержат $\approx 7$ мас. $\% \sum \operatorname{Tr}_{2} \mathrm{O}_{3}$. Повышенное относительное содержание в сумме РЗЭ иттрия и лантаноидов средней и иттриевой групп (табл. 33), возможность получения их на действующих производствах определяют интерес к этому техногенному продукту.

Основные характеристики использованного в работе фторфосфатного концентрата приведены в табл. 34.

Исследовали возможность разложения такого концентрата методом сорбционной конверсии. В качестве жидкой фазы использовали сернокислые растворы, поскольку полагали, что полученные в процессе серно-фосфорнофторсодержащие растворы можно утилизировать в основном производстве минеральных удобрений.

Таблица 33

Примерное соотношение индивидуальных РЗЭ

в продукционной экстракционной фосфорной кислоте $\left(\sum \mathrm{Tr}_{2} \mathrm{O}_{3}=100 \%\right)$

\begin{tabular}{|c|c|c|c|c|c|c|c|}
\hline \multicolumn{1}{|c|}{ Содержание, мас. \% } \\
\hline $\mathrm{Y}_{2} \mathrm{O}_{3}$ & $\mathrm{La}_{2} \mathrm{O}_{3}$ & $\mathrm{Ce}_{2} \mathrm{O}_{3}$ & $\mathrm{Pr}_{2} \mathrm{O}_{3}$ & $\mathrm{Nd}_{2} \mathrm{O}_{3}$ & $\mathrm{Sm}_{2} \mathrm{O}_{3}$ & $\mathrm{Eu}_{2} \mathrm{O}_{3}$ & $\mathrm{Gd}_{2} \mathrm{O}_{3}$ \\
\hline $12,7-13,4$ & $10,2-18,6$ & $32,2-36,2$ & $4,2-6,5$ & $15,9-24,1$ & $3,0-4,6$ & $1,0-1,25$ & $3,7-3,8$ \\
\hline $\mathrm{Tb}_{2} \mathrm{O}_{3}$ & $\mathrm{Dy}_{2} \mathrm{O}_{3}$ & $\mathrm{Ho}_{2} \mathrm{O}_{3}$ & $\mathrm{Er}_{2} \mathrm{O}_{3}$ & $\mathrm{Tm}_{2} \mathrm{O}_{3}$ & $\mathrm{Yb}_{2} \mathrm{O}_{3}$ & $\mathrm{Lu}_{2} \mathrm{O}_{3}$ & \\
\hline $0,38-0,42$ & 2,1 & 0,34 & 0,88 & 0,09 & 0,49 & 0,06 & \\
\hline
\end{tabular}


Состав фторфосфатного концентрата

\begin{tabular}{|c|c|c|c|c|c|c|c|c|c|c|c|}
\hline \multicolumn{10}{|c|}{ Основные компоненты } \\
\hline $\mathrm{Na}_{2} \mathrm{O}$ & $\mathrm{MgO}$ & $\mathrm{CaO}$ & $\mathrm{Al}_{2} \mathrm{O}_{3}$ & $\mathrm{SiO}_{2}$ & $\mathrm{TiO}_{2}$ & $\mathrm{Fe}_{2} \mathrm{O}_{3}$ & $\sum \mathrm{Tr}_{2} \mathrm{O}_{3}$ & $\mathrm{ThO}_{2}$ & $\mathrm{UO}_{2}$ & $\mathrm{~F}$ & $\mathrm{P}_{2} \mathrm{O}_{5}$ \\
\hline \multicolumn{8}{|c|}{ Содержание, мас. \%. } \\
\hline 4,39 & 8,07 & 8,28 & 17,65 & 16,45 & 0,097 & 0,53 & 7,295 & 0,10 & 0,00016 & 28,5 & 9,8 \\
\hline Относительное содержание в общем количестве г-экв. катионов концентрата, отн. \% \\
\hline 7,04 & 20,04 & 14,68 & 51,49 & - & - & 0,15 & 6,60 & - & - & - & - \\
\hline
\end{tabular}

Концентрат и сорбент, взятые в отношении $8 \mathrm{~cm}^{3}$ сорбента на 1 г концентрата, помещали в раствор 4 мас. \% $\mathrm{H}_{2} \mathrm{SO}_{4}$ (Ж : $\left.\mathrm{T}=13,3 \div 25\right)$, перемешивали в течение 1 ч при комнатной температуре. Выбранный расход катионита обеспечивал максимально сорбцию лишь 71,4 \% содержащихся в концентрате катионов $\mathrm{Na}, \mathrm{Mg}, \mathrm{Ca}, \mathrm{Al}$ и $\mathrm{P} 3 Э$, что позволяло надеяться, что на стадии сорбционной конверсии сорбент будет обогащаться более легко сорбируемыми РЗЭ. Разделяли сорбент и сернокислый раствор. Наблюдавшуюся в сернокислом растворе взвесь отфильтровывали, раствор и взвесь анализировали.

Исследовали влияние на эффективность конверсии отношения Ж : Т. Результаты опытов приведены в табл. 35 и 36.

Таблица 35

Распределение элементов между продуктами сорбционной конверсии при Ж : $\mathrm{T}=25$

\begin{tabular}{|l|c|c|c|c|c|c|c|c|}
\hline \multirow{2}{*}{ Продукт } & \multicolumn{8}{|c|}{ Извлечение в продукт, \% } \\
\cline { 2 - 9 } & $\mathrm{Na}$ & $\mathrm{Mg}$ & $\mathrm{Ca}$ & $\mathrm{Al}$ & $\mathrm{Ti}$ & $\mathrm{Fe}$ & $\mathrm{Th}$ & $\mathrm{U}$ \\
\hline Сорбент & 31,7 & 54,6 & 72,4 & 13,5 & - & 19,0 & 74,1 & 16,3 \\
\hline Раствор & 64,9 & 44,1 & 24,3 & 85,0 & 99,0 & 79,2 & 13,0 & 81,2 \\
\hline Взвесь & 3,4 & 1,3 & 3,3 & 1,5 & 0,7 & 1,8 & 12,9 & 2,5 \\
\hline & \multicolumn{8}{|c|}{ Извлечение в продукт, \% } \\
\cline { 2 - 10 } & $\mathrm{Y}$ & $\mathrm{La}$ & $\mathrm{Ce}$ & $\mathrm{Pr}$ & $\mathrm{Nd}$ & $\mathrm{Sm}$ & $\mathrm{Eu}$ & $\mathrm{Gd}$ \\
\hline Сорбент & 84,0 & 90,2 & 89,7 & 89,1 & 88,2 & 89,5 & 88,8 & 88,9 \\
\hline Раствор & 12,1 & 6,0 & 6,5 & 7,0 & 7,9 & 6,7 & 8,7 & 8,7 \\
\hline Взвесь & 3,9 & 3,8 & 3,8 & 3,9 & 3,9 & 3,8 & 3,5 & 3,4 \\
\hline & \multicolumn{8}{|c|}{ Извлечение в продукт, \% } \\
\cline { 2 - 10 } & Ть & Dу & Но & Еr & Тт & Yb & $\mathrm{Lu}$ & $\sum \mathrm{Tr}$ \\
\hline Сорбент & 86,7 & 86,3 & 86,0 & 85,8 & 85,7 & 85,3 & 74,1 & 88,4 \\
\hline Раствор & 10,3 & 11,1 & 11,6 & 11,9 & 12,2 & 12,5 & 24,0 & 7,8 \\
\hline Взвесь & 3,0 & 2,6 & 2,4 & 2,3 & 2,1 & 2,2 & 1,9 & 3,8 \\
\hline
\end{tabular}


Анализ данных табл. 35 и 36 показывает, что сорбционная конверсия позволяет переводить РЗЭ в сорбент, в то время как заметная часть многих примесных катионов остаётся в сернокислом растворе. Очевидно, что в пульпе остаются также кремнезём, фтор- и фосфорсодержащие анионы. Потери РЗЭ с маточным раствором, по-видимому, снизятся при снижении концентрации серной кислоты. Степень замещения протона в сульфокатионите на катионы металлов при уменьшении Ж : Т в исследованном интервале возрастала с 51,4 до $87,8 \%$.

Таблица 36

Распределение компонентов между продуктами сорбционной конверсии при Ж : Т = 8,7

\begin{tabular}{|l|c|c|c|c|c|c|c|c|}
\hline \multirow{2}{*}{ Продукт } & \multicolumn{10}{|c|}{ Извлечение в продукт, \% } \\
\cline { 2 - 9 } & $\mathrm{Na}$ & $\mathrm{Mg}$ & $\mathrm{Ca}$ & $\mathrm{Al}$ & $\mathrm{Ti}$ & $\mathrm{Fe}$ & $\mathrm{Th}$ & $\mathrm{U}$ \\
\hline Сорбент & 57,4 & 64,6 & 77,4 & 55,8 & 30,3 & 54,1 & 61,5 & 33,5 \\
\hline Раствор & 19,9 & 10,3 & 8,0 & 24,2 & 64,5 & 27,9 & 5,8 & 54,1 \\
\hline Взвесь & 22,7 & 25,1 & 14,6 & 20,0 & 5,2 & 18,0 & 32,7 & 12,4 \\
\hline & \multicolumn{8}{|c|}{ Извлечение в продукт, \% } \\
\cline { 2 - 10 } & $\mathrm{Y}$ & $\mathrm{La}$ & $\mathrm{Ce}$ & $\mathrm{Pr}$ & $\mathrm{Nd}$ & $\mathrm{Sm}$ & $\mathrm{Eu}$ & $\mathrm{Gd}$ \\
\hline Сорбент & 82,8 & 85,0 & 84,8 & 84,9 & 85,0 & 84,4 & 85,0 & 84,8 \\
\hline Раствор & 4,9 & 2,6 & 2,8 & 3,0 & 3,1 & 3,6 & 3,7 & 3,8 \\
\hline Взвесь & 12,4 & 12,4 & 12,4 & 12,2 & 11,9 & 12,1 & 11,3 & 11,4 \\
\hline & \multicolumn{8}{|c|}{ Извлечение в продукт, \% } \\
\cline { 2 - 10 } & $\mathrm{Tb}$ & Dу & Но & Еr & Тт & Yb & $\mathrm{Lu}$ & $\sum \mathrm{Tr}$ \\
\hline Сорбент & 84,3 & 84,3 & 84,1 & 84,0 & 84,1 & 83,3 & 83,4 & 84,6 \\
\hline Раствор & 4,6 & 5,0 & 5,5 & 5,6 & 5,8 & 5,9 & 5,7 & 3,3 \\
\hline Взвесь & 11,1 & 10,7 & 10,4 & 10,4 & 10,1 & 10,8 & 10,9 & 12,1 \\
\hline
\end{tabular}

Снижение объёма используемого при конверсии сернокислого раствора в исследованном интервале незначительно снижает степень перехода РЗЭ в сорбент, однако приводит к заметному увеличению сорбции натрия, алюминия, титана, железа, урана. Степень перехода в катионит различных РЗЭ достаточно близка, хотя для РЗЭ цериевой группы она несколько выше, чем для других, что определяется небольшим отличием их кислотно-основных свойств. В оптимальных условиях содержание в сорбенте оксидов РЗЭ относительно суммы оксидов сорбированных металлов превышало 31 мас. \%. Из примесей сорбент содержал значительное количество магния, кальция и алюминия. 
Разработка методов предварительного химического концентрирования РЗЭ во фтор-фосфатном концентрате представляется целесообразной.

Относительное количество взвесей, которые по сравнению с исходным концентратом незначительно обогащены торием, возрастает при снижении Ж : Т, по-видимому, из-за повышения концентрации в маточном растворе содержащих фтор и фосфор анионов, связывающих торий в малорастворимые соединения. Образование взвесей может быть уменьшено увеличением расхода сорбента, или они могут быть использованы в обороте.

Таким образом, показана возможность сорбционной конверсии в сернокислой среде фторфосфатного концентрата с извлечением в сульфокатионит РЗЭ с их отделением от кремния, фосфора, фтора и заметной части примесных катионов. 


\section{5. ПЕРЕРАБОТКА СОДЕРЖАЩИХ РЕДКОЗЕМЕЛЬНЫЕ ЭЛЕМЕНТЫ СОРБЕНТОВ}

В процессе сорбционной конверсии фосфатного, фторидного, фторфосфатного редкоземельного сырья получают сорбенты, обычно содержащие, кроме РЗЭ, щелочные и щелочноземельные элементы, природные радионуклиды (преимущественно торий), алюминий, железо (III), титан, марганец. Содержание РЗЭ и примесей в сорбентах, как показано выше, зависит от вида исходного сырья и условий проведения процесса. Для десорбции большинства катионов, особенно РЗЭ, эффективны концентрированные растворы солей аммония [27, 51] или натрия [52].

Имеет место парадоксальное замещение в сорбенте имеющих более высокую величину ионного потенциала полизарядных катионов однозарядными катионами с меньшей величиной ионного потенциала (табл. 37).

Таблица 37

Величины ионных потенциалов $z_{\mathrm{Me}^{n+}} / r_{\mathrm{Me}^{n+}}\left(\right.$ нм$\left.^{-1}\right)$ ряда катионов

\begin{tabular}{|l|l|l|l|l|l|l|l|l|l|l|l|l|}
\hline $\mathrm{Na}^{+}$ & $\mathrm{K}^{+}$ & $\mathrm{Mg}^{2+}$ & $\mathrm{Ca}^{2+}$ & $\mathrm{Sr}^{2+}$ & $\mathrm{Ba}^{2+}$ & $\mathrm{Mn}^{2+}$ & $\mathrm{Y}^{3+}-\mathrm{Lu}^{3+}$ & $\mathrm{Al}^{3+}$ & $\mathrm{Fe}^{3+}$ & $\mathrm{Ti}^{4+}$ & $\mathrm{Th}^{4+}$ & $\mathrm{U}^{4+}$ \\
\hline 10,2 & 7,5 & 25,6 & 18,8 & 15,8 & 14,0 & 22,0 & $24,6-30,3$ & 52,5 & 44,7 & 62,4 & 36,4 & 38,0 \\
\hline
\end{tabular}

Примечание. $z_{\mathrm{Me}^{n+}}$ - заряд катиона $\mathrm{Me}^{n+} ; r_{\mathrm{Me}^{n+}}$ - катионный радиус, нм.

Следует также учитывать, что катионы десорбата гидратированы, что определяет значительное увеличение радиуса гидратированного катиона и, как следствие, уменьшение его ионного потенциала. Степень гидратации десорбирующих катионов уменьшается при увеличении концентрации элюирующей соли, что увеличивает их ионный потенциал. Это является одним из факторов, определяющих необходимость использования для десорбции концентрированных растворов солей.

Десорбция полизарядных катионов растворами солей однозарядных катионов может быть объяснена только при допущениях, что перед десорбцией сорбированные катионы присоединяют анионные лиганды десорбата, что приводит к увеличению радиуса образующегося комплексного катиона и, как следствие, к уменьшению прочности его связи с функциональной группой сорбента, или/и сорбируются катионные комплексы с зарядом, меньшим, чем у катионов $\mathrm{Me}^{n+}$.

Исследование десорбции из катионита КУ-2-8чС показало, что при комнатной температуре концентрированными растворами хлорида, нитрата и сульфата натрия, а также нитрата и сульфата аммония могут достаточно 
эффективно десорбироваться катионы щелочных, щелочноземельных и редкоземельных металлов, а также алюминия, железа и марганца, однако десорбция титана, тория и урана затруднена. Увеличение температуры десорбции до $80{ }^{\circ} \mathrm{C}$ способствовало значительному повышению десорбции тория концентрированными (5-7 М) растворами хлорида и нитрата натрия, но не влияло на эффективность десорбции титана. Поскольку при переработке редкоземельного сырья количество попадающего в сорбент титана достаточно мало $(\leq 2,5 \%$ от общего количества эквивалентов сорбированных катионов), «отравление» сорбента вследствие накопления титана происходит достаточно медленно или не происходит совсем. При значительном накоплении титана в сорбенте его десорбцию можно проводить периодически содержащими фторион подкисленными растворами, например раствором 1 мас. $\% \mathrm{H}_{2} \mathrm{SO}_{4}$ и $0,1 \mathrm{M} \mathrm{NH}_{4} \mathrm{~F}[53]$.

Для извлечения РЗЭ из растворов сложного состава рекомендуются методы осаждения малорастворимых соединений РЗЭ - двойных сульфатов РЗЭ с натрием, фосфатов, фторидов, оксалатов. Однако наиболее перспективен процесс гидролитического осаждения гидроксидов или карбонатов РЗЭ, поскольку такие остатки, в отличие от получаемых другими методами, могут быть наименее затратно переработаны на целевую продукцию.

Последовательность гидролитического осаждения металлов определяется их концентрацией в растворе, величинами произведений растворимости (ПР) их гидроксидов и, как следствие, величинами $\mathrm{pH}$ начала $\left(\mathrm{pH}_{\mathrm{H}}\right)$ и конца $\left(\mathrm{pH}_{\mathrm{\kappa}}\right)$ осаждения. В табл. 38 приведены данные о ПР некоторых гидроксидов и рассчитанных на их основе величинах $\mathrm{pH}_{\mathrm{H}}$ и $\mathrm{pH}_{\mathrm{\kappa}}$ при допущении, что началу и концу осаждения соответствуют концентрации металлов в растворе, равные соответственно 1 и $10^{-6} \Gamma-и о н \cdot{ }^{-1}$ [54]. Из них следует, что Al, $\mathrm{Fe}^{3+}$, Th и U могут быть с высокой эффективностью отделены при нейтрализации раствора до $\mathrm{pH}=4,5-5,0$, а из оставшегося раствора нейтрализацией до $\mathrm{pH}=9,5$ осаждены РЗЭ, в то время как щелочноземельные элементы (исключением может быть магний, но его начальная концентрация обычно мала) будут количественно оставаться в растворе.

Известно, что эффективность разделения компонентов при гидролитическом осаждении зависит не только от величины $\mathrm{pH}$, но и от вида и способа введения нейтрализующего реагента. Эффективно «гомогенное» осаждение мочевиной, постепенно разлагающейся с выделением аммиака [55]. В производственных условиях этот метод неудобен, так как для расщепления мочевины необходима длительная выдержка нейтрализуемого раствора при температуре $90-100{ }^{\circ} \mathrm{C}$. Кроме того, трудно контролировать расход продукта, необходимый для обеспечения требуемой величины $\mathrm{pH}$. 
Произведения растворимости, $\mathrm{pH}_{\mathrm{H}}$ и $\mathrm{pH}_{\mathrm{K}}$ некоторых гидроксидов [54]

\begin{tabular}{|c|c|c|c|c|c|c|c|c|}
\hline \multirow{2}{*}{ Показатель } & \multicolumn{7}{|c|}{ Величина } \\
\cline { 2 - 9 } & $\mathrm{Mg}^{2+}$ & $\mathrm{Ca}^{2+}$ & $\mathrm{Sr}^{2+}$ & $\mathrm{Ba}^{2+}$ & $\mathrm{Al}^{3+}$ & $\mathrm{Fe}^{3+}$ & $\mathrm{Y}^{3+}$ & $\mathrm{Sc}$ \\
\hline$\Pi \mathrm{P}$ & $1,6 \cdot 10^{-11}$ & $7,9 \cdot 10^{-7}$ & $3,2 \cdot 10^{-4}$ & $1,6 \cdot 10^{-2}$ & $1,9 \cdot 10^{-33}$ & $1,0 \cdot 10^{-38}$ & $8,1 \cdot 10^{-23}$ & $2,0 \cdot 10^{-30}$ \\
\hline $\mathrm{pH}_{\mathrm{H}}$ & 8,50 & 10,85 & 12,15 & 13,00 & 2,99 & 1,43 & 6,54 & 4,00 \\
\hline $\mathrm{pH}_{\mathrm{K}}$ & 11,50 & 13,85 & - & - & 4,99 & 3,43 & 8,54 & 6,00 \\
\hline & $\mathrm{La}^{3+}$ & $\mathrm{Ce}^{3+}$ & $\mathrm{Pr}^{3+}$ & $\mathrm{Nd}^{3+}$ & $\mathrm{Sm}^{3+}$ & $\mathrm{Eu}^{3+}$ & $\mathrm{Gd}^{3+}$ & $\mathrm{Tb}^{3+}$ \\
\hline$\Pi \mathrm{P}$ & $1,0 \cdot 10^{-19}$ & $1,5 \cdot 10^{-20}$ & $2,7 \cdot 10^{-20}$ & $1,9 \cdot 10^{-21}$ & $6,8 \cdot 10^{-22}$ & $3,4 \cdot 10^{-22}$ & $2,1 \cdot 10^{-22}$ & $4,9 \cdot 10^{-27}$ \\
\hline $\mathrm{pH}$ & 7,67 & 7,29 & 7,38 & 6,99 & 6,84 & 6,74 & 6,67 & 5,13 \\
\hline $\mathrm{pH}_{\mathrm{\kappa}}$ & 9,67 & 9,29 & 9,38 & 8,99 & 8,84 & 8,74 & 8,67 & 7,13 \\
\hline & $\mathrm{Dy}^{3+}$ & $\mathrm{Ho}^{3+}$ & $\mathrm{Er}^{3+}$ & $\mathrm{Yb}^{3+}$ & $\mathrm{Lu}^{3+}$ & $\mathrm{Mn}^{2+}$ & $\mathrm{Th}^{4+}$ & $\mathrm{U}^{4+}$ \\
\hline$\Pi_{\mathrm{P}}$ & $1,3 \cdot 10^{-24}$ & $2,8 \cdot 10^{-27}$ & $1,3 \cdot 10^{-22}$ & $2,9 \cdot 10^{-24}$ & $2,5 \cdot 10^{-24}$ & $3,9 \cdot 10^{-14}$ & $1,0 \cdot 10^{-46}$ & $2,5 \cdot 10^{-50}$ \\
\hline $\mathrm{pH}_{\mathrm{H}}$ & 5,27 & 5,05 & 6,27 & 6,05 & 6,03 & 7,20 & 2,50 & 1,70 \\
\hline $\mathrm{pH}_{\mathrm{K}}$ & 7,27 & 7,05 & 8,27 & 8,05 & 8,03 & 10,20 & 4,00 & 3,20 \\
\hline
\end{tabular}

Близок к «гомогенному» метод, основанный на использовании для нейтрализации смеси газообразного аммиака и воздуха, взятых в мольном соотношении аммиак : воздух, равном $1:(2-4)$ [56].

Из растворов на основе 5 моль $\cdot^{-1}$ нитрата или сульфата аммония ступенчатой нейтрализацией газообразным аммиаком последовательно выделяли при $\mathrm{pH}=4,8-5,05$ торий, уран, титан, железо и значительную часть алюминия (ториевый кек), при $\mathrm{pH}=7,35-7,5$ - карбонатный концентрат Р3Э, при $\mathrm{pH}>8,5$ - остаток карбонатов щелочноземельных металлов. Потери РЗЭ с ториевым кеком составляли $0,1-0,5 \%$, кальций в него практически не попадал. С редкоземельным концентратом осаждалось 1,2-1,7 \% содержавшегося в растворе кальция [57]. Однако при использовании для нейтрализации раствора $\mathrm{NaOH}$ в выпавший при $\mathrm{pH}=5,0$ остаток попало $12,9 \%$ Р3Э.

Осаждение щелочноземельных металлов нейтрализацией газообразным аммиаком сложно, так как по мере повышения величины $\mathrm{pH}$ поглощение аммиака растворами солей аммония затрудняется. Использование газообразного аммиака на предприятиях, удалённых от его производства, создаёт организационно-технические проблемы. В ряде случаев попадание иона аммония в растворы технологически неприемлемо из-за затруднения утилизации или рекуперации маточных растворов. Кроме того, аммиак относится к пожаровзрывоопасным веществам.

Это определяет интерес к использованию для гидролитического осаждения других реагентов, среди которых целесообразны гидроксиды и карбонаты щелочных и щелочноземельных металлов. Однако в этом случае эффективность выделения РЗЭ значительно снижается. 
Так, при нейтрализации растворов азотнокислотного разложения перовскита суспензией гидроксида кальция с ториевым кеком при капельном введении суспензии осаждалось 17,1 \%, а при более быстром введении $29,4-51,8$ \% Р3Э [58].

При нейтрализации полученных при переработке лопаритового концентрата растворов до $\mathrm{pH}=5,0-5,8$ раствором гидроксида натрия с ториевым кеком осаждалось до 10 \% содержавшихся в растворах РЗЭ [59]. Это определяло не только высокие потери РЗЭ, но и увеличение массы подлежащего захоронению радиоактивного остатка.

При исследовании захвата РЗЭ остатком гидроксида железа, получавшимся при одновременном введении растворов, содержавших 0,2 моль $\cdot \pi^{-1} \mathrm{Fe}_{2}\left(\mathrm{SO}_{4}\right)_{3}$ и $50 \Gamma^{\cdot} \pi^{-1} \mathrm{NaOH}$, в нагретый до $75{ }^{\circ} \mathrm{C}$ содержащий сульфаты РЗЭ водный раствор с поддержанием $\mathrm{pH}=3,5$, заключили, что осаждение РЗЭ определяется не образованием мало растворимых двойных сульфатов с натрием, а адсорбцией РЗЭ на поверхности гидроксида железа [60]. При этом из растворов, содержавших $<1$ г/л РЗЭ цериевой группы, в остатки попадало до 70 \% РЗЭ, уменьшаясь до $15 \%$ в более концентрированных растворах. Соосаждение не образующих двойные сульфаты тяжёлых РЗЭ возрастало с увеличением их концентрации в растворе, достигая 5-8 мас. \% при концентрации РЗЭ $10 \Gamma^{\cdot} \pi^{-1}$.

Нами исследована возможность повышения эффективности гидролитического метода выделения РЗЭ из растворов сложного состава нейтрализацией гидроксидом или карбонатом натрия.

В работе использовали элюаты, полученные десорбцией 5 моль $\cdot{ }^{-1}$ раствором $\mathrm{NaNO}_{3}$ (сходные результаты были получены при десорбции 5 моль $\cdot{ }^{-1}$ раствором $\mathrm{NaCl}$ ) из катионита КУ-2-8чC, насыщавшегося при фосфорнокислотном разложении ловозёрского апатитового концентрата $[47,61]$. Они содержали (мг $\left.\pi^{-1}\right)$ 5157-5905 CaO, 703-1123 SrO, 3,85-10,8 MnO, 14,1-63,5 $\mathrm{Al}_{2} \mathrm{O}_{3}, \quad 18,8-31,0 \quad \mathrm{Fe}_{2} \mathrm{O}_{3}$, 559-881 $\sum \mathrm{Tr}_{2} \mathrm{O}_{3}, 0,6-4,1 \quad \mathrm{TiO}_{2}, 0,08-0,19 \mathrm{ThO}_{2}$, $0,003-0,008 \mathrm{UO}_{2}, 12-130 \mathrm{P}_{2} \mathrm{O}_{5}$ и имели $\mathrm{pH}=0,41-0,68$. Это соответствовало (мг-экв $\pi^{-1}$ ) 184-211 Ca, 13,6-21,7 Sr, 0,11-0,30 Mn, 0,83-3,74 Al, 0,70-1,16 Fe, $10,2-16,0 \sum \mathrm{Tr}, 0,03-0,21 \mathrm{Ti}, 0,001-0,003 \mathrm{Th},(4,4-12) \cdot 10^{-5} \mathrm{U}, 0,51-5,5 \mathrm{PO}_{4}{ }^{3-}$. По сравнению с использовавшимися в работе [57] растворами на основе солей аммония в элюатах содержание РЗЭ было примерно в 20 раз меньше, а кальция, железа и алюминия относительно РЗЭ значительно больше, что должно значительно осложнять выделение качественных концентратов РЗЭ.

Часть исследований выполнена $\mathrm{c}$ использованием модельных нитратных растворов, содержавших 5 моль $\pi^{-1} \mathrm{NaNO}_{3}$ и нитраты ряда элементов, концентрация которых в пересчёте на оксиды равнялась $\left(м \Gamma^{\cdot} \pi^{-1}\right)$ : 
$\mathrm{CaO} 5780, \mathrm{SrO} 1780, \mathrm{Al}_{2} \mathrm{O}_{3} 43, \mathrm{Fe}_{2} \mathrm{O}_{3} 84, \mathrm{Y}_{2} \mathrm{O}_{3} 206, \mathrm{La}_{2} \mathrm{O}_{3} 180, \mathrm{Ce}_{2} \mathrm{O}_{3} 990, \mathrm{Nd}_{2} \mathrm{O}_{3}$ 387. Раствор подкисляли $\mathrm{HNO}_{3}$ до $\mathrm{pH} 0,68$.

Опыты проводили при температуре $20{ }^{\circ} \mathrm{C}$. Для нейтрализации использовали карбонат натрия (ГОСТ 83-79), гидроксид натрия (ГОСТ 226379, марка ТР), а также их водные растворы и специально приготовленные сплавы с нитратом натрия. Для приготовления сплавов смесь взятых в заданном соотношении нитрата натрия (ГОСТ 4168-79, марка «Хч») и карбоната или гидроксида натрия расплавляли в корундизовых тиглях. Полученные расплавы быстро охлаждали, выливая тонким слоем на массивный металлический лист. Полученные пластины сплавов перед использованием измельчали до крупности -1 мм.

В предварительных опытах начало образования остатка контролировали визуально, при этом слабозаметное помутнение наблюдалось лишь при $\mathrm{pH}=4,9-5,0$. Позже с помощью эффекта Тиндаля найдено, что образование твёрдой фазы начинается уже при $\mathrm{pH}=1,6-1,8$.

Нейтрализующие реагенты вводили при интенсивном перемешивании: водные растворы каплями, твёрдые постепенной загрузкой. После достижения заданного значения $\mathrm{pH}$ образовавшийся остаток отфильтровывали, маточный раствор анализировали. По изменению концентраций в растворе оценивали степень осаждения компонентов и составы образовывавшихся остатков.

В предварительных опытах нейтрализацию элюатов до $\mathrm{pH}=4,9-5,0$ провели раствором $\mathrm{Na}_{2} \mathrm{CO}_{3}$ концентрацией $104 \Gamma^{\circ} \pi^{-1}\left(1,96\right.$ г-экв· $\left.{ }^{-1}\right)$ и раствором

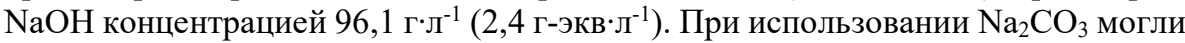
осаждаться не только гидроксиды, но и менее растворимые и более легко фильтрующиеся карбонаты ряда элементов.

При нейтрализации раствором $\mathrm{Na}_{2} \mathrm{CO}_{3}$ после прекращения подачи нейтрализующего реагента величина $\mathrm{pH}$ раствора постепенно самопроизвольно увеличивалась с 4 до 5. Это объясняется тем, что при введении достаточно концентрированного раствора $\mathrm{Na}_{2} \mathrm{CO}_{3}$ в растворе частично образуется соединение $\mathrm{Na}_{2} \mathrm{CO}_{3} \cdot \mathrm{CaCO}_{3} \cdot 5 \mathrm{H}_{2} \mathrm{O}$ [62]. Оно постепенно распадается с выделением в раствор $\mathrm{Na}_{2} \mathrm{CO}_{3}$, что и вызывает увеличение $\mathrm{pH}$ раствора. При медленном введении нейтрализующего раствора наблюдалось также снижение величины рН с 7,6 до 6,4, что определялось большим индукционным периодом кристаллизации $\mathrm{CaCO}_{3}$ в концентрированных растворах нитрата натрия. Кислотность раствора могла возрастать, если при кристаллизации $\mathrm{CaCO}_{3}$ концентрация ионов кальция в растворе начинала резко снижаться, и эквивалентное количество осаждавшегося в единицу времени иона $\mathrm{Ca}^{2+}$ превышало количество подаваемого иона $\mathrm{Na}^{+}$.

Степень осаждения компонентов при нейтрализации до $\mathrm{pH}=5$, при котором визуально наблюдалось начало образования остатков, приведена в табл. 39. 
Степень осаждения компонентов при нейтрализации до $\mathrm{pH}=5,0$ растворами карбоната и гидроксида натрия

\begin{tabular}{|c|c|c|c|c|c|c|c|c|c|}
\hline \multirow{2}{*}{ Раствор } & \multicolumn{10}{|c|}{ Извлечение в остаток, отн. \% } \\
\cline { 2 - 10 } & $\mathrm{Al}$ & $\mathrm{Ti}$ & Fe & Mn & Th & $\mathrm{U}$ & $\sum \mathrm{Tr}$ & $\mathrm{Ca}$ & $\mathrm{Sr}$ \\
\hline $\mathrm{Na}_{2} \mathrm{CO}_{3}$ & 99,7 & 94,3 & 79,1 & 75,0 & 92,7 & 69,1 & 98,2 & 16,7 & 0,33 \\
\hline $\mathrm{NaOH}$ & 90,6 & 99,9 & 10,2 & 25,7 & 71,8 & 86,1 & 99,6 & 27,4 & 19,1 \\
\hline
\end{tabular}

Сопоставление данных табл. 39 и данных работы [57] показало, что если при нейтрализации растворов на основе концентрированных солей аммония (концентрация аммонийной группы 3,5-4,5 г-экв $\pi^{-1}$ ) газообразным аммиаком до $\mathrm{pH}=5$ в ториевый кек редкоземельные и щелочноземельные металлы из сульфатных растворов практически не осаждались, а из нитратных осаждались в малой степени, то при нейтрализации концентрированными растворами карбоната или гидроксида натрия осаждалась бо́льшая часть РЗЭ, заметная часть кальция, а при использовании гидроксида натрия также стронция. При последующей длительной выдержке полученных суспензий составы остатков и растворов не менялись.

Высокая степень осаждения РЗЭ и кальция не может быть связана с наличием в элюатах фосфат-иона, как это наблюдалось в работе [63], так как концентрация фосфора в растворах мала и он количественно оставался в растворе. Она также не определяется сорбцией на гидроксидах более легко гидролизующихся элементов, как это предложено в работе [60], так как в остатках сумма эквивалентных количеств РЗЭ и кальция значительно превосходила эквивалентное количество более легко гидролизующихся элементов.

Степень осаждения определялась не только значением конечной величины $\mathrm{pH}$, но и зависела от вида нейтрализующего реагента: гидроксидом натрия значительно хуже осаждались железо, марганец, торий, лучше кальций и особенно стронций. Растворимость гидроксида стронция в воде значительно превышает растворимость гидроксида кальция, а растворимость карбоната кальция значительно меньше растворимости гидроксида кальция. «Аномальное» поведение стронция указывает на усиление образования при введении $\mathrm{NaOH}$ им и другими гидролизующимися катионами полимерных гидроксидных комплексов сложного состава, растворимость которых много меньше растворимости гидроксида стронция.

При введении нейтрализующего реагента в виде раствора или твёрдого продукта на границе его контакта с нейтрализуемым раствором неизбежны локальные отличия величины $\mathrm{pH}$ от измеряемого среднего значения. Поэтому при нейтрализации могут осаждаться не только компоненты, гидролизующиеся 
при измеряемом среднем значении $\mathrm{pH}$, но и компоненты, устойчивые к гидролизу при данном среднем значении $\mathrm{pH}$. При этом образуются гидроксидные комплексы сложного состава. Состав этих комплексов зависит от элементного состава раствора, соотношения концентраций элементов в растворе и локальных градиентов $\mathrm{pH}$, определяющихся видом, концентрацией и способом введения нейтрализующего реагента. При последующем усреднении состава раствора выщелачивание более трудно гидролизующихся компонентов из таких комплексов не происходило.

Следовательно, для достижения эффективного разделения необходим метод введения $\mathrm{Na}_{2} \mathrm{CO}_{3}$ или $\mathrm{NaOH}$, препятствующий возникновению в нейтрализуемом растворе значительных градиентов $\mathrm{pH}$. Предположили, что это может быть достигнуто, если нейтрализацию проводить сплавами $\mathrm{Na}_{2} \mathrm{CO}_{3}$ или $\mathrm{NaOH} \mathrm{с} \mathrm{использовавшейся} \mathrm{для} \mathrm{десорбции} \mathrm{солью.} \mathrm{При} \mathrm{растворении} \mathrm{таких}$ сплавов нейтрализующий реагент будет поступать в раствор постепенно, что должно приводить к уменьшению локального градиента концентрации ионов гидроксила.

Анализ диаграмм плавкости систем $\mathrm{Na}_{2} \mathrm{CO}_{3}-\mathrm{NaNO}_{3}$ и $\mathrm{NaOH}-$ $\mathrm{NaNO}_{3}$ [64] показал, что в системе $\mathrm{Na}_{2} \mathrm{CO}_{3}-\mathrm{NaNO}_{3}$ наиболее перспективны доэвтектические составы с концентрацией $\mathrm{Na}_{2} \mathrm{CO}_{3} C_{\mathrm{Na}_{2} \mathrm{CO}_{3}} \leq 3$ мас. \%, не содержащие в качестве отдельной фазы кристаллы $\mathrm{Na}_{2} \mathrm{CO}_{3}$. Представляют интерес также сплавы в системе $\mathrm{NaOH}-\mathrm{NaNO}_{3}$, где образуются твёрдые растворы на основе $\mathrm{NaOH} \cdot \mathrm{NaNO}_{3}$ и $2 \mathrm{NaOH} \cdot \mathrm{NaNO}_{3}$ и в широком интервале концентраций отсутствует фаза $\mathrm{NaOH}$. Не исключалось, что при резком охлаждении сплавов $\mathrm{Na}_{2} \mathrm{CO}_{3}-\mathrm{NaNO}_{3}$ с $C_{\mathrm{Na}_{2} \mathrm{CO}_{3}}>3$ мас. \% будут образовываться очень мелкие кристаллы $\mathrm{Na}_{2} \mathrm{CO}_{3}$, которые, находясь в избытке кристаллов $\mathrm{NaNO}_{3}$, будут растворяться медленно, что также позволит снизить локальные градиенты концентрации нейтрализующего реагента и, как следствие, иона гидроксила.

С целью экономии расхода сплавов и уменьшения количества вводимого в раствор $\mathrm{NaNO}_{3}$ нейтрализацию до $\mathrm{pH}=1,6-1,8$, при котором наблюдалось зародышеобразование твёрдой фазы, проводили концентрированным раствором $\mathrm{NaOH}$. Результаты исследования влияния изменения концентрации $\mathrm{Na}_{2} \mathrm{CO}_{3} C_{\mathrm{Na}_{2} \mathrm{CO}_{3}}$ в его сплавах с $\mathrm{NaNO}_{3}$ на степень осаждения РЗЭ и щелочноземельных элементов при нейтрализации до $\mathrm{pH}=5$ приведены в табл. 40. В отличие от наблюдавшегося при использовании концентрированного раствора $\mathrm{Na}_{2} \mathrm{CO}_{3}$ после завершения введения содержащих $\mathrm{Na}_{2} \mathrm{CO}_{3}$ солевых сплавов $\mathrm{pH}$ растворов не менялся. 
Влияние концентрации $\mathrm{Na}_{2} \mathrm{CO}_{3}\left(C_{\mathrm{Na}_{2} \mathrm{CO}_{3}}\right)$ в его сплавах с $\mathrm{NaNO}_{3}$ на степень осаждения элементов при нейтрализации до $\mathrm{pH}=5$

\begin{tabular}{|c|c|c|c|c|c|c|c|c|}
\hline \multirow{2}{*}{$\begin{array}{c}C_{\mathrm{Na}_{2} \mathrm{CO}_{3}}, \\
\text { мас. } \%\end{array}$} & $\mathrm{Al}$ & $\mathrm{Ti}$ & $\mathrm{Fe}$ & $\mathrm{Th}$ & $\mathrm{U}$ & $\mathrm{Y}$ & $\mathrm{La}$ & $\mathrm{Ce}$ \\
\hline 2,5 & 46,4 & 100 & 80,4 & 91,9 & 100 & 11,9 & 0,21 & 0,20 \\
\hline 5,0 & H. a. & H. a. & H. a. & H. a. & H. a. & 13,3 & 5,3 & 13 \\
\hline 7,5 & H. a. & H. a. & H. a. & H. a. & H. a. & 20,0 & 10,5 & 14 \\
\hline 11 & H. a. & H. a. & H. a. & H. a. & H. a. & 29,4 & 12,8 & 40,8 \\
\hline 15 & H. a. & H. a. & H. a. & H. a. & H. a. & 29,4 & 18,3 & 43,0 \\
\hline & Pr & Nd & Sm & Eu & Gd & $\sum \mathrm{Tr}$ & Ca & $\mathrm{Sr}$ \\
\hline 2,5 & 1,02 & 2,95 & 9,73 & 9,28 & 1,58 & 1,16 & 0,14 & 0 \\
\hline 5,0 & H. a. & 13,3 & H. a. & H. a. & H. a. & 11,6 & 0,2 & 0 \\
\hline 7,5 & H. a. & 13,3 & H. a. & H. a. & H. a. & 14,1 & 0,2 & 0 \\
\hline 11 & 27,9 & 41,1 & 21,4 & H. a. & 68,4 & 34,5 & 8,06 & 0 \\
\hline 15 & 35,1 & 49,2 & 32,6 & H. a. & 68,4 & 38,8 & 9,63 & 0 \\
\hline
\end{tabular}

Из данных табл. 40 видно, что при нейтрализации до $\mathrm{pH}=5$ сплавом, содержавшим 2,5 мас. \% $\mathrm{Na}_{2} \mathrm{CO}_{3}$, в ториевый кек попало 1,16 \% суммы Р3Э, а в концентрат РЗЭ 0,14\% - кальция. Увеличение концентрации $\mathrm{Na}_{2} \mathrm{CO}_{3}$ в сплаве приводило к быстрому возрастанию захвата ториевым кеком Р3Э, а концентратом РЗЭ кальция. Степень осаждения РЗЭ с большей основностью - цериевой (исключение - лантан) и средней групп - могла превышать степень осаждения более легко гидролизующегося иттрия. Это также подтверждает обсуждаемый характер гидролитического осаждения металлов в растворах, содержащих компоненты со значительно отличающейся гидролитической устойчивостью.

При нейтрализации до $\mathrm{pH}=4,4-4,8$ даже при использовании сплавов, содержавших 15 мас. \% $\mathrm{Na}_{2} \mathrm{CO}_{3}$ или 15-30 мас. \% NaOH, захват ториевым кеком РЗЭ и щелочноземельных элементов резко снижался (табл. 41). Высокая степень осаждения $\mathrm{Al}$ и $\mathrm{Fe}$ достигалась уже при $\mathrm{pH} \geq 4,6$ при нейтрализации сплавами, содержащими $\mathrm{Na}_{2} \mathrm{CO}_{3}$, и при $\mathrm{pH} \geq 4,4$ при нейтрализации сплавами, содержащими $\mathrm{NaOH}$. Осаждение РЗЭ с ториевым кеком зависело от вида нейтрализующего реагента: при $\mathrm{pH}=4,6$ и использовании сплава, содержащего $\mathrm{NaOH}$, осаждение РЗЭ цериевой группы было больше, а иттрия меньше, чем при использовании сплава, содержащего $\mathrm{Na}_{2} \mathrm{CO}_{3}$. 
Зависимость эффективности гидролитического осаждения от концентрации $C$ в сплавах $\mathrm{Na}_{2} \mathrm{CO}_{3}$ или $\mathrm{NaOH}$ и величины $\mathrm{pH}$

\begin{tabular}{|c|c|c|c|c|c|c|c|c|c|}
\hline \multirow{2}{*}{$\begin{array}{c}C, \\
\text { мас. \% }\end{array}$} & \multirow{2}{*}{$\mathrm{pH}$} & \multicolumn{8}{|c|}{ Степень осаждения, \% } \\
\cline { 2 - 9 } & $\mathrm{Al}$ & $\mathrm{Fe}$ & $\mathrm{Y}$ & $\mathrm{La}$ & $\mathrm{Ce}$ & $\mathrm{Nd}$ & $\mathrm{Ca}$ & $\mathrm{Sr}$ \\
\hline \multirow{2}{*}{15} & 4,6 & 88,4 & 96,4 & 5,00 & 1,23 & 0,90 & 3,95 & 1,38 & 0,79 \\
\cline { 2 - 10 } & 4,8 & 88,4 & 96,4 & 5,00 & 1,23 & 1,10 & 5,26 & 1,38 & 0,79 \\
\hline \multicolumn{10}{|c}{ Сплавы $\mathrm{NaNO}_{3}+\mathrm{NaOH}$} \\
\hline \multirow{2}{*}{15} & 4,4 & 50,0 & 91,7 & 0,50 & 0,53 & 0,10 & 0,26 & 0,13 & 0,33 \\
\cline { 2 - 10 } & 4,6 & 88,4 & 94,0 & 3,40 & 2,79 & 1,01 & 5,94 & 0,69 & 0,79 \\
\hline \multirow{2}{*}{30} & 4,4 & 82,6 & 94,0 & 2,73 & 2,06 & 2,04 & 1,68 & 1,46 & 1,16 \\
\cline { 2 - 9 } & 4,6 & 82,6 & 94,0 & 3,43 & 2,63 & 2,06 & 2,10 & 1,64 & 1,16 \\
\hline
\end{tabular}

При анализе данных табл. 41 следует учитывать, что в сплавах крупность кристаллов $\mathrm{Na}_{2} \mathrm{CO}_{3}$ или $\mathrm{NaOH} \cdot \mathrm{NaNO}_{3}$ (существует при концентрации $\mathrm{NaNO}_{3} \geq 70$ мас. \%) может зависеть от условий охлаждения расплава, влияя на возникающие при растворении частиц сплавов локальные градиенты концентрации нейтрализующего реагента.

В таблице 42 приведены результаты по нейтрализации элюата сплавами, содержащими по 30 мас. \% $\mathrm{Na}_{2} \mathrm{CO}_{3}$ или $\mathrm{NaOH}$. Видно, что количественное осаждение тория, определяющего возможную радиоактивность концентрата Р3Э, достигалось при $\mathrm{pH}=4,4$. При этом осаждение алюминия, железа, титана, марганца было относительно невелико, а потери РЗЭ значительны (6,7-7,5 \%). При нейтрализации до $\mathrm{pH}=7,35$ достигалась высокая степень осаждения РЗЭ при небольшом соосаждении щелочноземельных элементов, причём при нейтрализации содержащим $\mathrm{NaOH}$ сплавом попадание щелочноземельных элементов, особенно стронция, в концентрат РЗЭ немного возросло.

Итак, для достижения эффективного разделения содержащихся в растворе компонентов на групповые концентраты целесообразно сначала нейтрализовать раствор концентрированными растворами $\mathrm{Na}_{2} \mathrm{CO}_{3}$ или $\mathrm{NaOH}$ до $\mathrm{pH}=1,6-1,8$, продолжить нейтрализацию сплавом $\mathrm{NaNO}_{3}-\mathrm{Na}_{2} \mathrm{CO}_{3}$ с доэвтектическим содержанием $\mathrm{Na}_{2} \mathrm{CO}_{3}$, осаждая при $\mathrm{pH}=4,4$ ториевый кек, после чего осаждать концентрат Р3Э при $\mathrm{pH}=7,35$, нейтрализуя раствор сплавами $\mathrm{NaNO}_{3}-\mathrm{Na}_{2} \mathrm{CO}_{3}$ или $\mathrm{NaNO}_{3}-\mathrm{NaOH}$, содержащими до 30 мас \% нейтрализующего реагента. Осаждение щелочноземельных металлов при $\mathrm{pH}=10$ следует проводить концентрированными растворами $\mathrm{Na}_{2} \mathrm{CO}_{3}$ или $\mathrm{NaOH}$. 
Таблииа 42

Зависимость эффективности осаждения при нейтрализации сплавами на основе $\mathrm{NaNO}_{3}$, содержащими 30 мас. \% карбоната или гидроксида натрия

\begin{tabular}{|c|r|r|r|r|r|r|r|r|r|r|}
\hline \multirow{2}{*}{ pH } & \multicolumn{10}{|c|}{ Степень осаждения, \% } \\
\cline { 2 - 11 } & $\mathrm{Al}$ & $\mathrm{Ti}$ & $\mathrm{Fe}$ & $\mathrm{Mn}$ & $\mathrm{Th}$ & $\mathrm{U}$ & $\sum \mathrm{Tr}$ & $\mathrm{Mg}$ & $\mathrm{Ca}$ & $\mathrm{Sr}$ \\
\hline \multicolumn{10}{|c}{ Слав 70 \% $\mathrm{NaNO}_{3}+30 \% \mathrm{Na}_{2} \mathrm{CO}_{3}$} \\
\hline $0,4-4,4$ & 25,6 & 38,8 & 30,6 & 12,2 & 92,6 & 46,3 & 6,7 & 12,8 & 0,08 & 0 \\
\hline $4,4-7,35$ & 71,2 & 3,4 & 4,8 & 0 & 4,3 & 0 & 93,1 & 4,0 & 0,39 & 0,03 \\
\hline $7,35-10$ & 0,6 & 0 & 48,8 & 86,7 & 2,0 & 17,1 & 0,2 & 83,1 & 99,43 & 99,87 \\
\hline $0,4-10$ & 97,4 & 42,2 & 84,2 & 98,9 & 98,9 & 63,4 & 100 & 99,9 & 99,9 & 99,9 \\
\hline \multicolumn{10}{|c|}{ Сплав 70\% $\mathrm{NaNO}_{3}+30 \% \mathrm{NaOH}$} \\
\hline $0,5-4,4$ & 50,8 & 34,1 & 53,9 & 32,6 & 98,9 & 61,0 & 7,5 & 15,4 & 0,47 & 0,27 \\
\hline $4,4-7,35$ & 42,7 & 8,8 & 8,0 & 10,6 & 0,8 & 3,6 & 92,4 & 7,6 & 0,12 & 0 \\
\hline $7,35-10$ & 2,6 & 3,9 & 33,4 & 56,7 & 0,2 & 34,2 & 0,1 & 76,9 & 99,31 & 99,63 \\
\hline $0,5-10$ & 96,1 & 46,8 & 95,3 & 97,9 & 99,9 & 98,8 & 100 & 99,9 & 99,9 & 99,9 \\
\hline
\end{tabular}

Расчёт на основании представленных выше экспериментальных данных показывает, что извлечение РЗЭ в карбонатный или гидроксидный концентрат составит не менее 98,6 \% при содержании $\sum \operatorname{Tr}_{2} \mathrm{O}_{3}$ относительно

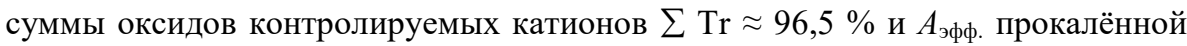
суммы оксидов менее 400 Бк'кг-1.

\section{Выводы}

1. При нейтрализации растворов сложного состава, содержащих алюминий, титан, марганец, железо, торий, уран, щелочноземельные элементы, концентрированными растворами $\mathrm{Na}_{2} \mathrm{CO}_{3}$ и $\mathrm{NaOH}$ значительное осаждение Р3Э и щелочноземельных элементов с ториевым кеком наблюдается при $\mathrm{pH}=5$, намного меньшем величин $\mathrm{pH}$ начала осаждения их индивидуальных гидроксидов. Это объяснено образованием в растворе при таком методе введения нейтрализующего реагента зон с повышенной щёлочностью, в которых образуются прочные гидроксидные комплексы сложного состава, содержащие как гидролизующиеся при измеряемом среднем значении $\mathrm{pH}$, так и устойчивые к гидролизу компоненты.

2. Предложено использовать для нейтрализации растворов сложного состава содержащие $\mathrm{Na}_{2} \mathrm{CO}_{3}$ или $\mathrm{NaOH}$ солевые сплавы. При этом установлено, что: 1) потери РЗЭ при осаждении ториевого кека нейтрализацией до величины $\mathrm{pH}=5$ с использованием сплава $\mathrm{NaNO}_{3}-\mathrm{Na}_{2} \mathrm{CO}_{3}$, содержавшего $\approx 3$ мас. $\% \mathrm{Na}_{2} \mathrm{CO}_{3}$ в виде твёрдого раствора в $\mathrm{NaNO}_{3}$, снизились с 98,2-99,6 до 1,16 \%; 2) при использовании 
для нейтрализации сплава $\mathrm{NaNO}_{3}-\mathrm{NaOH}$, содержащего 15 мас. \% $\mathrm{NaOH}$, снижение величины $\mathrm{pH}$ осаждения с 5,0 до 4,4 позволяет снизить потери РЗЭ с ториевым кеком; 3) при замене водных растворов $\mathrm{Na}_{2} \mathrm{CO}_{3}$ или $\mathrm{NaOH}$ для нейтрализации до $\mathrm{pH} \approx 7,35$ сплавами на основе $\mathrm{NaNO}_{3}$, содержащими до 30 мас $\% \mathrm{Na}_{2} \mathrm{CO}_{3}$ или $\mathrm{NaOH}$, резко снижается захват концентратом РЗЭ щелочноземельных металлов, прежде всего кальция.

3. Обоснована оптимальная схема гидролитического выделения РЗЭ из растворов сложного состава нейтрализацией содержащими $\mathrm{Na}_{2} \mathrm{CO}_{3}$ или $\mathrm{NaOH}$ водорастворимыми сплавами, обеспечивающая получение нерадиоактивного концентрата РЗЭ с извлечением не менее 98,6 \%. 


\section{6. ПУТИ ПРАКТИЧЕСКОЙ РЕАЛИЗАЦИИ МЕТОДА СОРБЦИОННОЙ КОНВЕРСИИ}

Перечень разработанных технических решений обобщён в табл. 43.

Таблииа 43

Перечень разработанных технических решений по переработке фосфатного, фторидного, фтор-фосфатного редкоземельного сырья методом сорбционной конверсии

\begin{tabular}{|c|c|c|c|c|c|}
\hline \multirow[b]{2}{*}{ Концентрат } & \multicolumn{2}{|c|}{ Кислота } & \multirow[b]{2}{*}{$t,{ }^{\circ} \mathrm{C}$} & \multirow[b]{2}{*}{ Торий } & \multirow{2}{*}{$\begin{array}{c}\text { Использование } \\
\text { маточного } \\
\text { раствора }\end{array}$} \\
\hline & вид & $\begin{array}{c}C, \\
\text { мас } \%\end{array}$ & & & \\
\hline \multirow[t]{2}{*}{ Бастнезитовый } & $\mathrm{H}_{2} \mathrm{SO}_{4}$ & $\leq 2$ & $20-80$ & Кек & В обороте ${ }^{*}$ \\
\hline & $\mathrm{HNO}_{3}$ & $\leq 2,5$ & $20-80$ & То же & To жe $^{*}$ \\
\hline \multirow[t]{2}{*}{ Иттрофлюоритовый } & $\mathrm{HNO}_{3}$ & $\leq 2,5$ & $20-80$ & $»$ & $\gg{ }^{*}$ \\
\hline & $\mathrm{HF}$ & 1,0 & $20-80$ & $\gg$ & $\gg$ \\
\hline Монацитовый & $\mathrm{H}_{3} \mathrm{PO}_{4}$ & $38-40$ & $60-80$ & $»$ & $\gg$ \\
\hline \multirow[t]{3}{*}{ Фосфатный } & $\mathrm{HNO}_{3}$ & 2 & $20-80$ & $\gg$ & $\begin{array}{l}\text { В производстве } \\
\text { удобрений }\end{array}$ \\
\hline & $\mathrm{HNO}_{3}+\mathrm{F}$ & $1-2,5$ & $20-80$ & 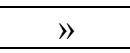 & То же \\
\hline & $\mathrm{H}_{3} \mathrm{PO}_{4}$ & $20-25$ & 20 & Раствор & $\gg$ \\
\hline Фтор-фосфатный & $\mathrm{H}_{2} \mathrm{SO}_{4}$ & 4 & 20 & Кек & $»$ \\
\hline
\end{tabular}

* Накапливающийся фтор периодически осаждается карбонатом кальция.

Полученные в настоящей работе и ранее [52] результаты показывают целесообразность использования для переработки фосфатного, фторидного, фтор-фосфатного природного и техногенного редкоземельного сырья представленной на рис. 3 универсальной технологической схемы.

Она включает следующие основные технологические процессы:

- разложение сырья слабокислыми растворами в присутствии сульфокатионита (сорбционную конверсию);

- десорбцию из сорбента поглощённых им металлов;

- последовательное раздельное осаждение из полученного при десорбции элюата радиоактивного примесного кека, нерадиоактивного концентрата карбонатов РЗЭ, карбонатов щелочноземельных металлов;

- регенерацию сорбента из $\mathrm{Na}^{+}$- в $\mathrm{H}^{+}$-форму;

- в случае экономической целесообразности регенерацию гидроксида натрия и используемой для регенерации сорбента кислоты. 


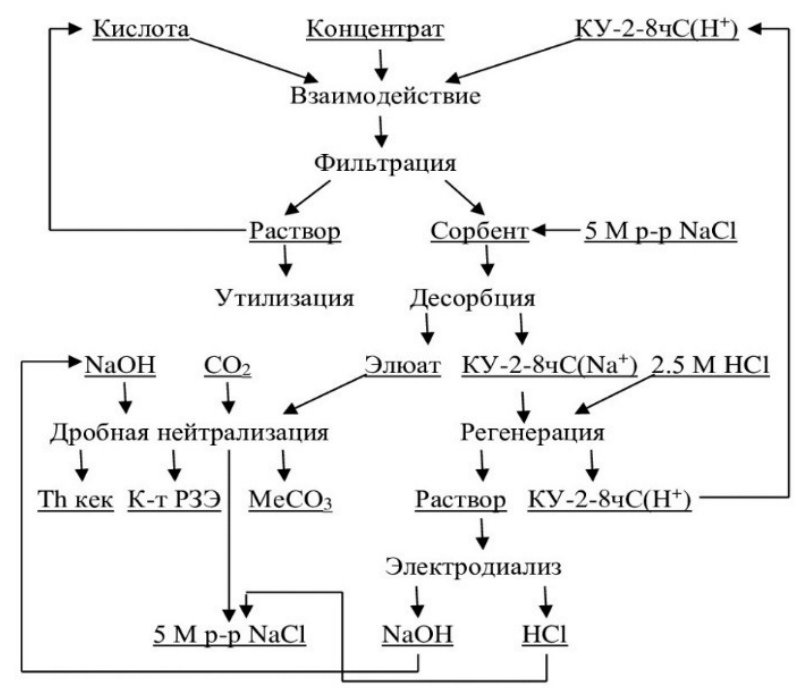

Рис. 3. Универсальная принципиальная технологическая схема переработки фосфатного, фторидного, фтор-фосфатного редкоземельного сырья методом сорбционной конверсии

Вид и концентрация используемого для разложения кислотного раствора определяется свойствами содержащего РЗЭ продукта, а также необходимостью обеспечения оптимальных условий для целесообразной утилизации получающихся маточных кислотных растворов. Продукты, содержащие гидратированные фосфаты и фториды РЗЭ, растворимы в достаточной степени уже в разбавленных растворах минеральных кислот. Безводные фосфаты РЗЭ нерастворимы в таких растворах, поэтому для переработки монацита использованы концентрированные растворы ортофосфорной кислоты.

Судя по низкому содержанию катионных примесей в маточных кислотных растворах (см. табл. 3, 14, 27, 31), они в незначительной степени нейтрализуют кислотность маточных растворов, что открывает возможность использования этих растворов в обороте. Этому может препятствовать накопление в растворах фтора и фосфора. Найдено, что из серно-, азотно- и солянокислых маточных растворов сорбционной конверсии значительная часть фосфора и фтора по мере их накопления может быть осаждена частичной нейтрализацией карбонатом кальция. Так, из азотно- и солянокислых растворов переработки бастнезитового концентрата нейтрализацией общей кислотности 
на 70-75 \% осаждалось до 95,4 \% фтора в виде фторида кальция, из сернокислых нейтрализацией общей кислотности на $60 \%$ осаждалось $\geq 50 \%$ фтора в виде смеси фторида и сульфата кальция [65].

Поэтому маточные растворы процесса сорбционной конверсии, получаемые при переработке природного сырья, используются в обороте непосредственно или после осаждения накапливающихся в них фтора и/или фосфора. Маточные растворы процесса сорбционной конверсии, получаемые при переработке техногенного сырья, утилизируются в основном производстве предприятий, на которых это сырьё получено.

После десорбции растворами солей натрия сорбент переходит в $\mathrm{Na}^{+}$-форму. Регенерация сорбента в $\mathrm{H}^{+}$-форму и утилизация получающихся при этом растворов рассмотрена ранее [66].

Содержащиеся в сырье торий и уран в основном попадают в сорбент и затем десорбируются. Из элюатов основная часть тория и значительная часть урана обычно осаждаются в начале нейтрализации в виде содержащего ряд других примесей (алюминий, железо, титан) кека, состав которого зависит от вида перерабатываемого сырья. Для переработки фосфатного концентрата РЗЭ, получаемого при азотнокислотной переработке апатитового концентрата, найдены условия, позволяющие исключить образование продуктов с повышенной радиоактивностью.

В лабораторных опытах по исследованию сорбционной конверсии исходный редкоземельный продукт, сорбент и раствор перемешивали в реакторе, что могло приводить к истиранию или механическому разрушению гранул сорбента. Поэтому сконструирована, изготовлена и испытана укрупнённая лабораторная установка для разложения сырья методом сорбционной конверсии, позволяющая исключить разрушение сорбента. Принципиальная схема и общий вид установки приведены на рис. 4. Она состоит из сорбционной колонки 1 , реактора 2 с верхнеприводной мешалкой, промежуточной ёмкости 3 , дозировочного насоса 4 , термостата 5 , соединительных шлангов, запорных струбцин 6 и 7, соединительного патрубка 8 .

Сорбционная колонка, реактор с мешалкой, промежуточная ёмкость изготовлены из полипропилена или полиэтилена, соединительные шланги - из силиконовой резины.

Используемый для разложения раствор заливают в промежуточную ёмкость 3, включают дозировочный насос 4 и перекачивают раствор в сорбционную колонку 1 и реактор 2. После заполнения раствором сорбционной колонки 1 и реактора 2 в последний загружают разлагаемый концентрат, включают мешалку реактора и при необходимости термостат, ведут процесс разложения заданное время. 

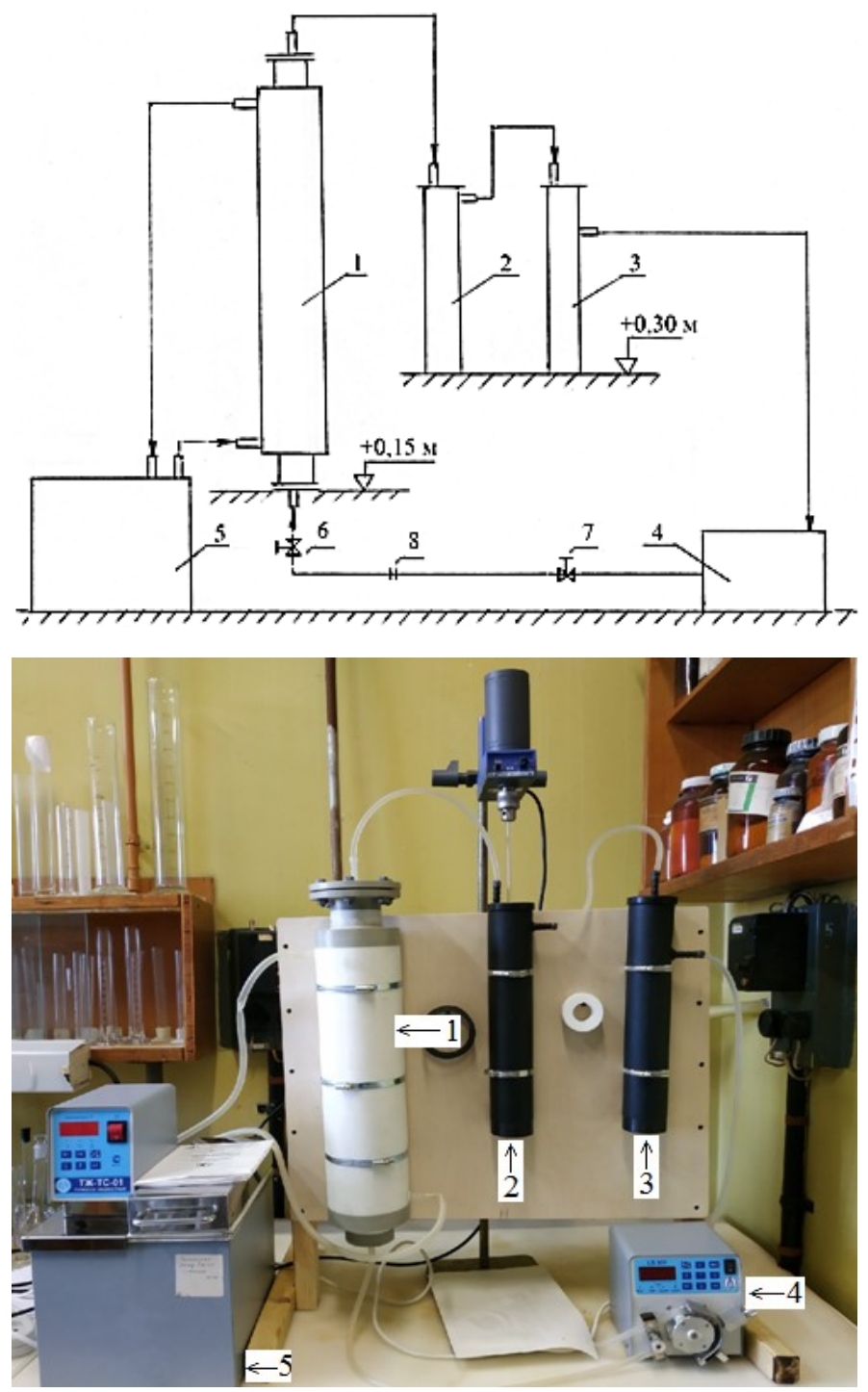

Рис. 4. Принципиальная схема и общий вид укрупнённой лабораторной установки для сорбционной конверсии 
Число оборотов мешалки выбирается таким, чтобы исключать сильное взмучивание и унос в промежуточную ёмкость разлагаемого продукта. Однако, если вытекающим из реактора раствором твёрдая фаза всё же будет захвачена, она осаждается в промежуточной ёмкости, не попадая в дозировочный насос.

После завершения разложения концентрата отключают мешалку и термостат, перекрывают запорные устройства на шланге подачи раствора в сорбционную колонку. Между запорными устройствами разъединяют соединительный шланг, открывают запорное устройство, сливают раствор из сорбционной колонки. 


\section{ЗАКЛЮЧЕНИЕ}

Эффективность применения метода сорбционной конверсии для переработки фосфатного, фторидного, фтор-фосфатного природного и техногенного редкоземельного сырья определяется рядом факторов.

- высвобождающиеся при разложении этих продуктов ортофосфорная или/и фтористоводородная кислоты являются слабыми кислотами, поэтому их постепенное накопление в жидкой фазе по мере разложения редкоземельных концентратов мало сказывается на её кислотности и, следовательно, на эффективности поглощения катионов сульфокатионитом;

- из растворов исследовавшегося состава РЗЭ сорбируются наиболее полно по сравнению с другими катионными компонентами;

- возможна эффективная десорбция из сульфокатионита РЗЭ и большинства сопутствующих катионов концентрированными растворами солей аммония и натрия, при этом кислотность элюата в процессе десорбции возрастает в слабой, но достаточной для предотвращения гидролитического осаждения десорбированных металлов степени;

- низкая кислотность получающихся элюатов обеспечивает низкий расход нейтрализующих реагентов при гидролитическом осаждении десорбированных металлов;

- значительное отличие гидролитической устойчивости РЗЭ и примесных металлов создает возможность их разделения в процессе гидролитического осаждения с получением с высоким выходом нерадиоактивного богатого редкоземельного концентрата.

Из представленных в работе результатов, которые могут быть улучшены при системной оптимизации предложенных подходов, следуют основные достоинства технологий переработки фосфатного, фторидного, фторфосфатного редкоземельного сырья с использованием метода сорбционной конверсии: высокое извлечение РЗЭ, в том числе иттрия и лантаноидов средней и тяжёлой групп; минимальный расход материалов; минимум жидких и твёрдых отходов; энергоэффективность, так как большинство технологических операций (разложение концентратов, переработка сорбента и элюата) проводится при более низких температурах, чем в известных технологиях; возможность использования более дешёвых материалов для изготовления аппаратуры, коррозионное разрушение которой снижается из-за низкой кислотности растворов и температуры используемых процессов; отсутствие вредных выделений в газовую фазу соединений фтора, аммиака.

Таким образом, предлагаемые технические решения перспективны для переработки фосфатного, фторидного, фтор-фосфатного природного и техногенного редкоземельного сырья. При наличии заинтересованных заказчиков достигнутые результаты при углублённой разработке могут быть улучшены. 


\section{ЛИТЕРАТУРА}

1. Комплексная азотнокислотная переработка фосфатного сырья / А. Л. Гольдинов и др. Л.: Химия, 1982. 207 с.

2. Локшин Э. П., Тареева О. А., Елизарова И. Р. Извлечение редкоземельных элементов из экстракционной фосфорной кислоты дигидратного процесса // ЖПХ. 2013. Т. 86, № 5. С. 623-628.

3. Gupta C. K., Krishnamurthy N. Extractive Metallurgy of Rare Earths. London; New York; Washington: CRC Press, 2005. 522 p.

4. Sadri F., Nazari A. M., Ghahreman A. A review on the cracking, baking and leaching processes of rare earth element concentrates // Journal of Rare Earths. 2017. Vol. 35. P. 739-752.

5. Локшин Э. П. Сорбционная конверсия - перспективный метод переработки редкоземельного сырья // Труды Кольского научного центра РАН. Химия и материаловедение. Вып. 2, ч. 1. Апатиты: КНЦ РАН, 2018. № 1 (9). C. 154-159. DOI: 10.25702/KSC.2307-5252.2018.9.1.154-159

6. Pat. DDR 262845. C 01 F 17/00, C 22 B 59/00. Verfahren zum Aufschluß von Bastnäsitkonzentraten / H. Richter, A. Schmitt, L. Lesh, G. Merker. Заявл. 31.07.87; опубл. 14.12.88.

7. Kruesi P. R., Duker G. Production of rare earth chloride from bastnesit // J. Metals. 1965. Vol. 17. P. 847-849.

8. Обращение с минеральным сырьём и материалами с повышенным содержанием природных радионуклидов. Санитарные правила и нормы СП-2.6.1.798-99. М.: Минздрав России, 2000. 11 с.

9. Aplan F. F. The processing of rare earth metals. Rare earths: extraction, preparation and application // Processings of the TMS Annual Meeting. Las Vegas, Nevada. Feb 27-Mart 2. 1988. P. 15-34.

10. Дистилляционная отгонка HF из кислых фторидно-сульфатных растворов / М. Л. Беликов и др. // Химия в интересах устойчивого развития. 2017. T. 25, № 5. C. 473-478. DOI: 10.15372/ KhUR20170501

11. Киргинцев А. Н., Трушникова Л. Н., Лаврентьев В. Г. Растворимость неорганических веществ в воде. Л.: Химия, 1972. 248 с.

12. Определение произведения растворимости фторида иттрия / А. Махмадмуродов и др. // Доклады АН Таджикской ССР. 1972. Т. 15, № 9. С. 40-43.

13. Икрами Д. Д., Комилова Г., Хаитова М. О растворимости фторидов лантана и скандия в азотной кислоте // Доклады АН Таджикской ССР. 1973. Т. 16, № 3. С. 65-69. 
14. Рахматуллаев К., Талипов Ш. Т., Юсупова Р. Исследование растворимости четыреххлористого церия в плавиковой кислоте // Доклады АН Узбекской CCP. 1962. № 4. C. 46-49.

15. Буслаев Ю. А., Густякова М. П. О растворимости $\mathrm{ThF}_{4}$ в HF // ЖНХ. 1965. T.10, № 3. C. 662-665.

16. Mechano-chemical decomposition of monazite to assist the extraction of rare earth elements / W. Kim et al. // J. Alloys and Compounds. 2009. Vol. 486, No. 1-2. P. 610-614.

17. Abdel-Rehim A. M. An innovative method for processing Egyptian monazite // Hydrometallurgy. 2002. Vol. 67. P. 9-17.

18. Combined approaches for comprehensive processing of rare earth metal ores / V. I. Kuzmin et al. // Hydrometallurgy. 2012. Vol. 129-130, No. 11. P. 1-6.

19. Merritt R. R. High temperature methods for processing monazite: 1. Reaction with calcium chloride and calcium carbonate // J. Common Met. 1990. Vol. 166, No. 2. P. 197-212.

20. Пат. 2242528 Рос. Федерация, МПК С 22 В 60/02; 59/00; C 01 G 56/00; С 01 F 17/00 Способ вскрытия монацитового концентрата / Косенко В. П., Жуков В. Т., Пехов Г. Ф., Казанцев В. Н.; Открытое акционерное общество «Ульбинский металлургический завод» (KZ). № 2002108901/02; заявл. 08.04.2002; опубл. 20.12.2004, Бюл. № 35 .

21. Пат. 2331681 Рос. Федерация, МПК С 22 В 59/00 (2006.01), С 22 В 60/02 (2006.01). Способ разложения монацита / Низов В. А., Обабков Н. В., Смирнов А. Л., Михеев А. А., Терентьев Г. Д., Сметанников В. П., Косынкин В. Д., Леонтьев В. Ф; ГУПСО «Урал Монацит Техно» (Государственное унитарное предприятие Свердловской области «Урал Монацит Техно») (RU). № 2004113426/02; заявл. 30.04.2004; опубл. 20.08.2008, Бюл. № 23.

22. Информационно-аналитический электронный ресурс: URL: http://www.monazite.ru/monazite.

23. Локшин Э. П., Калинников В. Т. Извлечение РЗЭ из промпродуктов и отходов сернокислотной переработки апатитового концентрата // Материалы Международного научно-практического семинара «Переработка и утилизация попутных фтористых соединений и извлечение редкоземельных металлов в производстве минеральных удобрений». М.: НИУИФ, 2011. С. 125-141.

24. Пат. 2465207 Рос. Федерация, МПК С 01 F 17/00, С 22 В 59/00 (2006.01). Способ извлечения редкоземельных элементов из экстракционной фосфорной кислоты / Локшин Э. П., Тареева О. А.; Ин-т химии и технологии редких элементов и минер. сырья Кол. науч. центра РАН. № 2011128682/05; заявл. 11.07.2011; опубл. 27.10.2012, Бюл. № 30. 
25. Локшин Э. П., Тареева О. А., Елизарова И. Р. Переработка апатитового концентрата методом сорбционной конверсии // Труды Кольского научного центра РАН. Химия и материаловедение. Вып. 2, ч. 1. 2018. № 1 (9). C. 175-180. DOI: 10.25702/KSC.2307-5252.2018.9.1.175-180

26. Локшин Э. П., Тареева О. А., Елизарова И. Р. Исследование сорбционной конверсии фосфатного редкоземельного концентрата в фосфорнокислой среде // Химическая технология. 2019. № 1. С. 42-48. DOI: 10.31044/16845811-2019-20-1-42-48

27. Локшин Э. П., Тареева О. А. Разработка технологий извлечения редкоземельных элементов при сернокислотной переработке хибинского апатитового концентрата на минеральные удобрения: Апатиты: КНЦ РАН, 2015. $268 \mathrm{c}$.

28. Тананаев И. В., Васильева В. П. О растворимости фосфата лантана в растворах фосфорной кислоты // Журнал неорганической химии. 1964. Т. 9, № 9. С. 213-214.

29. Василенко Н. А., Чепелевецкий М. Л. Растворимость фосфата лантана в водных растворах фосфорной кислоты при $80^{\circ} / /$ Журнал неорганической химии. 1957. Т. 2, № 10. С. 2486-2489.

30. Сергеева Н. М., Кузьменков М. И. Исследование системы $\mathrm{La}_{2} \mathrm{O}_{3}-\mathrm{H}_{3} \mathrm{PO}_{4}$ $\mathrm{H}_{2} \mathrm{O} / /$ Журнал неорганической химии. 1983. Т. 28, № 8. С. 2157-2159.

31. Ульянов А. И., Казакова Т. И. Изучение системы $\mathrm{CePO}_{4}-\mathrm{H}_{3} \mathrm{PO}_{4}-\mathrm{H}_{2} \mathrm{O}$ при $25^{\circ} / /$ Изв. АН СССР. Серия химическая. 1963. № 7. С. 1157-1164.

32. Свешникова В. Н., Гинзбург В. Л. Изучение тройной системы фосфат церия - фосфорная кислота - вода при $70{ }^{\circ} \mathrm{C} / /$ Журнал неорганической химии. 1962. Т. 7, № 5. С. 1169-1173.

33. Kijkowska R. Preparation of lanthanide orthophosphates by crystallization from phosphoric acid solution // Journal of Materials Science. 2003. Vol. 38. P. 229-233.

34. Вулих А. И. Ионообменный синтез. М.: Химия, 1973. 232 с.

35. Горелов А. М., Штин А. П. Исследования свойств фосфорнокислых растворов титана // Труды Института химии УФ АН СССР. 1970. Вып. 20. C. $106-110$.

36. Локшин Э. П., Тареева О. А. Взаимодействие катионов алюминия, железа (III) и титанила с $\mathrm{SiF}_{6}{ }^{2-}$ в серно- и азотнокислых средах // ЖПХ. 2015. T. 88, № 9. C. 1364-1368. DOI 10.1134/S1070427215090268

37. Пат. 2458863 Рос. Федерация, МПК С 01 F 7/00 (2006.01). Способ извлечения редкоземельного концентрата из апатита / Таук М. В., Николаева И. И., Осьмак А. В., Горшкова Н. В., Спахова Л. В.; Открытое акционерное общество «Акрон» (RU); № 2011105109/02; заявл. 14.02.2011; опубл. 20.08.2012, Бюл. № 23. 
38. Пат. 2148019 Рос. Федерация, МПК ${ }^{7}$ C 01 F 17/00, С 22 В 3/06. Способ переработки фосфатного редкоземельного концентрата, выделенного из апатита / Лебедев В. Н., Сергеева С. Д., Маслобоев В. А., Локшин Э. П.; Ин-т химии и технологии редких элементов и минер. сырья Кол. науч. центра РАН. № 98121493/12; заявл. 23.11.1998; опубл. 27.04.2000, Бюл. № 12.

39. Локшин Э. П., Лебедев В. Н. Выделение фосфора из фосфатсодержащих редкоземельных материалов углетермическим восстановлением // Журнал прикладной химии. 1999. Т. 72, № 2. С. 184-190.

40. Моисеев В. Д., Семёнов В. А., Шелехова Г. А. Экстракционная очистка фосфатного редкоземельного концентрата, получаемого при переработке апатита // Химическая промышленность 1981. № 8. С. 24-27.

41. Пат. 2532773 Рос. Федерация, МПК С 22 В 59/00, С 22 В 3/06, С 22 В 3/26 (2006.01). Способ переработки фосфатного редкоземельного концентрата / Таук М. В., Николаева И. И., Маклашина Е. А., Салдаева Г. В; Открытое акционерное общество «Акрон» (RU). № 2013134737; заявл. 25.07.2013; опубл. 10.11.2014, Бюл. № 31 .

42. Локшин Э. П., Тареева О. А. Особенности сернокислотного выщелачивания лантаноидов из фосфополугидрата // ЖПХ. 2008. Т. 81, № 1. C. $10-15$.

43. О растворимости ортофосфатов редкоземельных элементов в азотной кислоте / Т. И. Кузина и др. // Изв. высш. учебн. заведений. Цветная металлургия. 1994. № 1-2. С. 68-70.

44. Локшин Э. П., Тареева О. А., Елизарова И. Р. Сорбционная конверсия фосфатных концентратов редкоземельных металлов // ЖПХ. 2014. Т. 87, № 8. C. $1038-1043$.

45. Пат. 2590796 Рос. Федерация, МПК С 22 В 3/08, 59/00 (2006.01). Способ переработки фосфогипса / Локшин Э. П., Тареева О. А.; Ин-т химии и технологии редких элементов и минер. сырья Кол. науч. центра РАН. № 2015111977/02; заявл. 01.04.2015; опубл. 10.07.2016, Бюл. № 19.

46. Пат. 2612244 Рос. Федерация, МПК С 22 В 59/00, 3/06, 3/24 (2006.01). Способ обработки фосфатного концентрата РЗЭ / Локшин Э. П., Тареева О. А.; Ин-т химии и технологии редких элементов и минер. сырья Кол. науч. центра РАН. № 2015148565/05; заявл. 11.11.2015; опубл. 03.03.2017, Бюл. № 7.

47. Локшин Э. П., Тареева О. А., Елизарова И. Р. Новый подход к переработке апатитового концентрата // ЖПХ. 2016. Т. 89, № 7. С. 887-893.

48. Процесс извлечения РЗЭ из экстракционной фосфорной кислоты на ОАО «ФосАгро-Череповец» / А. С. Сибилев и др. // Химическая технология. 2015. № 4. C. 201-205. 
49. Пат. 2509169 Рос. Федерация, МПК С 01 F 17/00, С 22 В 59/00 (2009.01). Способ извлечения редкоземельных элементов из экстракционной фосфорной кислоты / Локшин Э. П., Тареева О. А., Калинников В. Т.; Ин-т химии и технологии редких элементов и минер. сырья Кол. науч. центра РАН. № 2013115544/02; заявл. 05.04.2013; опубл. 10.03.2014, Бюл. № 7.

50. Локшин Э. П., Тареева О. А., Елизарова И. Р. Осаждение редкоземельных элементов из экстракционной фосфорной кислоты соединениями фтора // ЖПХ. 2011. Т. 84, № 5. С. 743-751.

51. Локшин Э. П., Тареева О. А., Елизарова И. Р. Переработка фосфодигидрата с выделением редкоземельных элементов и получением очищенного от фосфатов и фторидов гипса // ЖПХ. 2011. Т. 84, № 9. С. 1409-1417.

52. Локшин Э. П., Тареева О. А., Елизарова И. Р. Переработка сульфокатионита, насыщавшегося в процессе фосфорнокислотного разложения хибинского апатитового концентрата // Химическая технология. 2019. Т. 20, № 4. С. 163-170. DOI: 10.31044/1684-5811-201920-4-163-170

53. Kenna B. T., Conrad F. J. Separation of Titanium by Cation Exchange and its Spectrophotometric Determination with Disodium-1,2-dihydroxybenzene-3,5disulfonate // Anal. Chem. 1963. Vol. 35, No. 9. P. 1255-1257.

54. Семин Б. Д., Кушниров Ю. Ф. К вопросу фракционного разделения гидроокисей металлов // Металлургия цветных металлов. Сборник научных трудов Красноярского института цветных металлов. 1971. № 4. C. 190-196.

55. Вассерман И. М. Химическое осаждение из растворов. Л.: Химия, 1980. $280 \mathrm{c}$.

56. Пат. 2104938 Рос. Федерация Россия, МПК ${ }^{6}$ C 01 F 17/00. Способ извлечения редкоземельных элементов из фосфогипса / Вальков А. В., Вальков Д. А.; Товарищество с ограниченной ответственностью «Мицар». № 96119235/25; заявл. 26.09.96; опубл. 20.02.98, Бюл. № 5.

57. Локшин Э. П., Тареева О. А., Елизарова И. Р. Выделение редкоземельных элементов из растворов аммонийных солей // Химическая технология. 2014. № 4. C. 222-226. DOI: 10.1134/S0040559515040144

58. Выделение железо-ториевого кека из технологических растворов после азотнокислотного вскрытия перовскитового концентрата / Н. В. Мудрук и др. // Цветные металлы. 2017. № 6. С. 63-68. DOI: 10/17580/tsm.2017.06.10

59. Косынкин В. Д., Макаров В. Д., Шаталов В. И. Очистка редких земель лопарита от радиоактивных примесей // Развитие редкометалльной промышленности в России на базе лопаритового концентрата: сб. тр. IV науч. конф. СПб.: Элис СПб, 2001. С. 153-158. 
60. Riley E., Dutrizac J. E. The behaviour of the rare earth elements during the precipitation of ferrihydrite from sulphate media // Hydrometallurgy. 2017. Vol. 172. P. 69-78.

61. Пат. 2624575 Рос. Федерация, МПК С 22 В 3/06, С 01 В 25/22, С 22 В 59/00, 3/24 (2006.01). Способ переработки апатитового концентрата / Локшин Э. П., Тареева О. А.; Ин-т химии и технологии редких элементов и минер. сырья Кол. науч. центра РАН. № 2016140755/02; заявл. 17.10.2016; опубл. 04.07.2017, Бюл. № 19.

62. Справочник по растворимости. Т. 2, кн. 2. Л.: Наука, 1969. 1170 с.

63. Upgrading of a rare earth phosphate concentrate within the nitrophosphate process / M. Alemrajabi et al. // Journal of Cleaner Production. 2018. Vol. 198. P. 551-564.

64. Посыпайко В. И., Алексеева Е. А., Васина Н. А. Диаграммы плавкости солевых систем. Ч. ІІІ. Двойные системы с общим катионом. М.: Металлургия, 1979. 204 с.

65. Локшин Э. П., Тареева О. А. Исследование переработки бастнезитового концентрата методом сорбционной конверсии // Химическая технология. 2019. T. 20, № 9. С. 414-421.

66. Локшин Э. П., Тареева О. А., Седнева Т. А. Переработка апатитового концентрата методом сорбционной конверсии. Апатиты: ФИЦ КНЦ РАН, 2018. $64 \mathrm{c}$. 

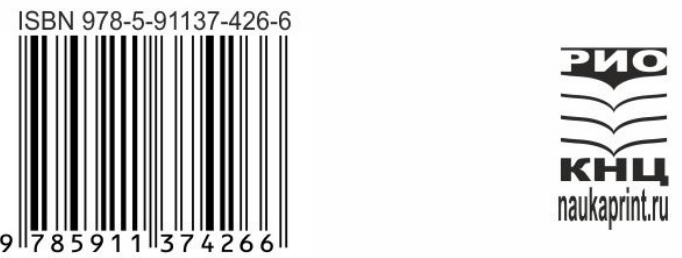

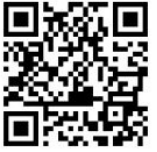

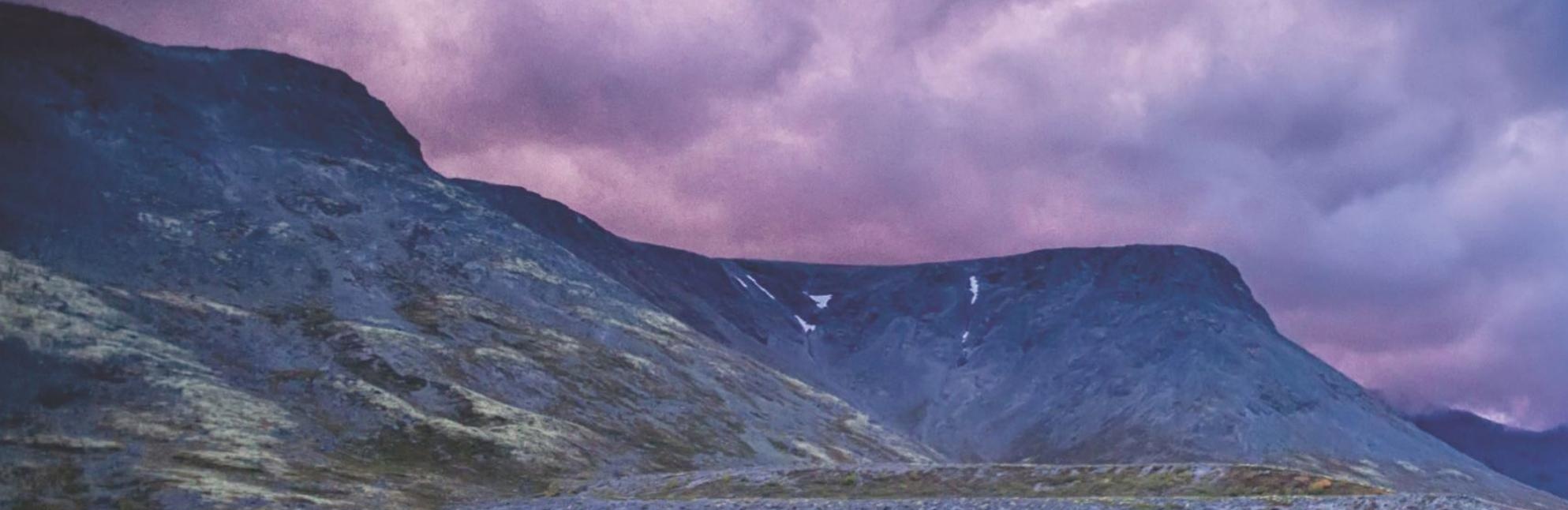

istoris

naukaprintill
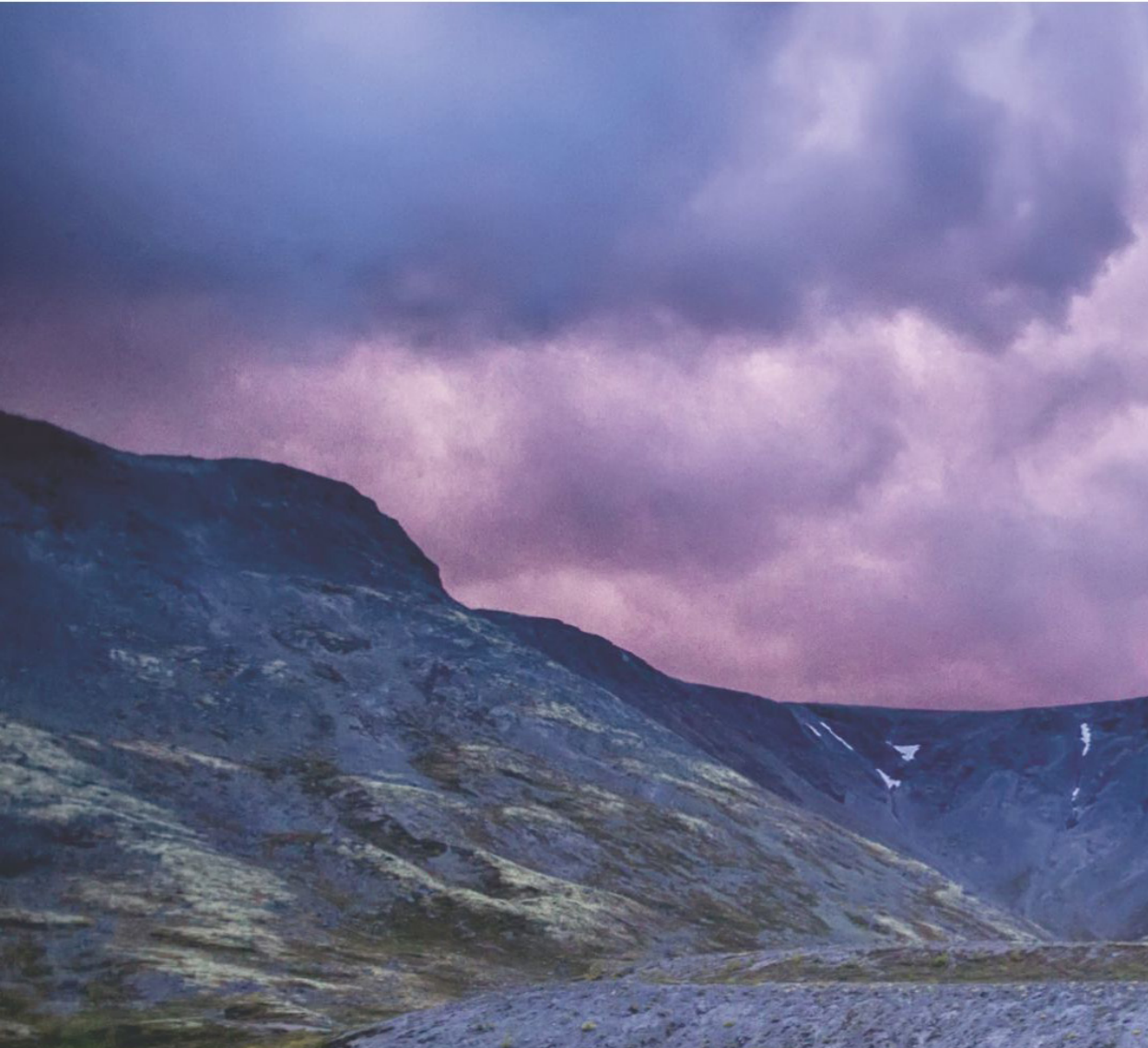

5

ation

9.

3.

$1+21$

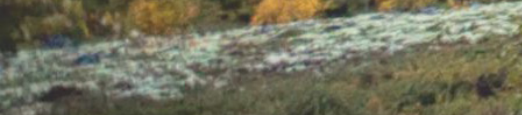

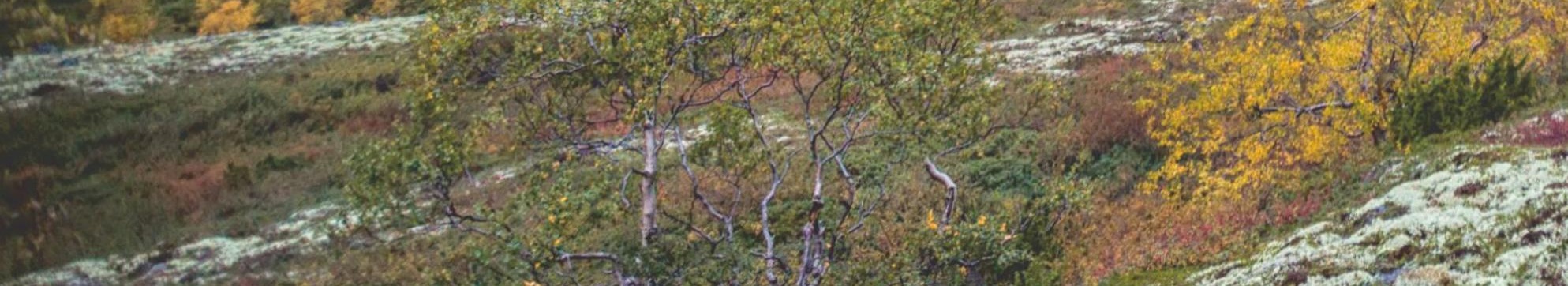

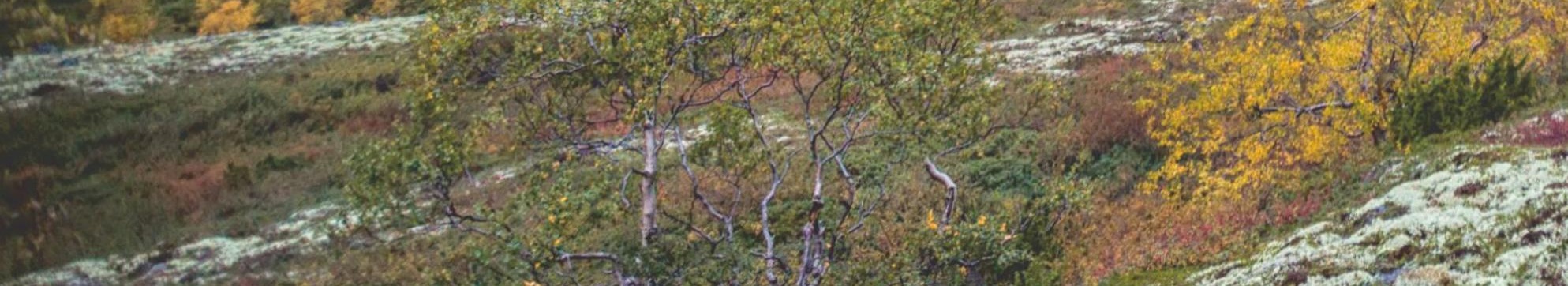

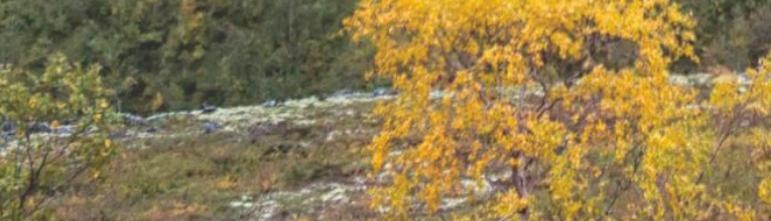

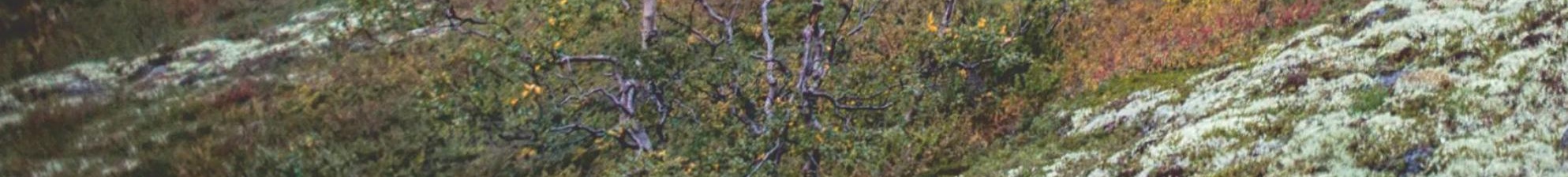

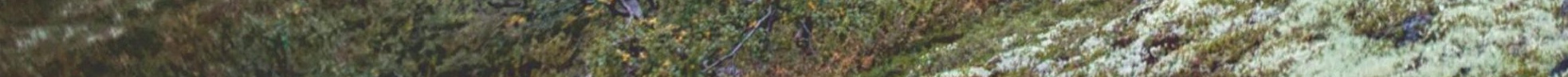
A S.t.

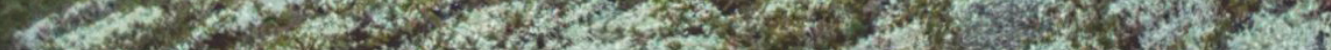

